\title{
Effects of Well Discharges on Hydraulic Heads in and Spring Discharges from the Geothermal Aquifer System in the Bruneau Area, Owyhee County, Southwestern Idaho
}

By Charles Berenbrock

U.S. Geological Survey

Water-Resources Investigations Report 93-4001

Prepared in cooperation with

U.S. FISH AND WILDLIFE SERVICE 


\title{
U.S. DEPARTMENT OF THE INTERIOR \\ BRUCE BABBITT, Secretary
}

\author{
U.S. GEOLOGICAL SURVEY
}

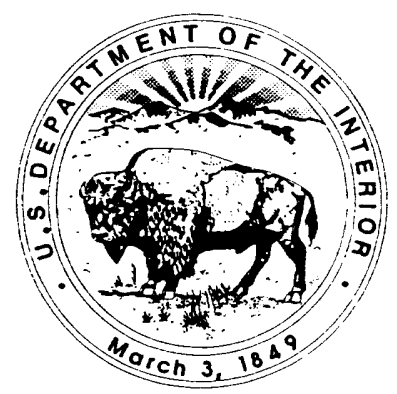

Dallas L. Peck, Director

Any use of trade, product, or firm names in this publication is for descriptive purposes

only and does not imply endorsement by the U.S. Government

For additional information write to:

District Chief

U.S. Geological Survey

230 Collins Road

Boise, ID 83702
Copies of this report can be purchased from: U.S. Geological Survey Books and Open-File Reports Section Federal Center, Box 25425

Denver, CO 80225 


\section{CONTENTS}

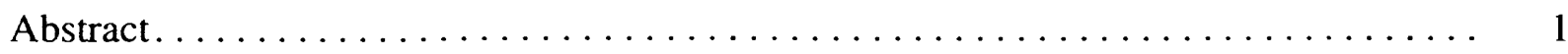

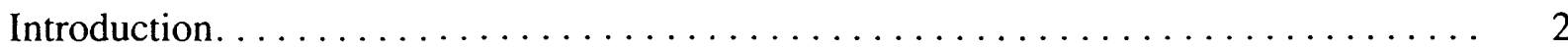

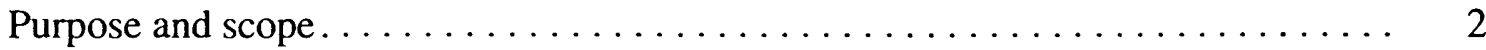

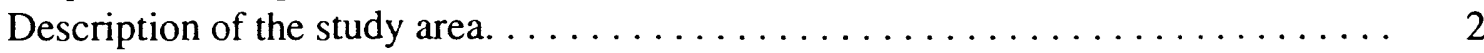

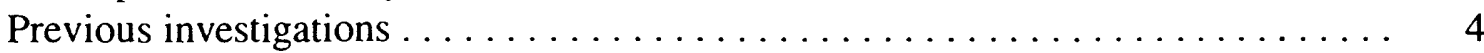

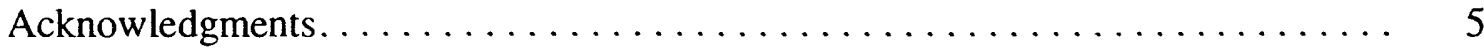

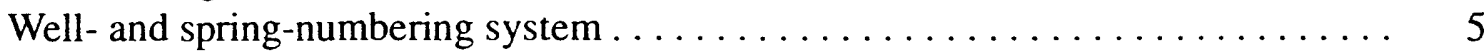

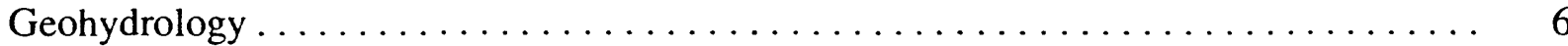

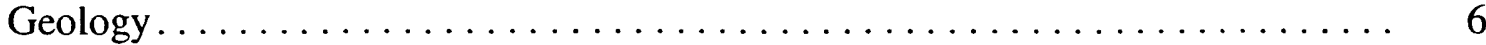

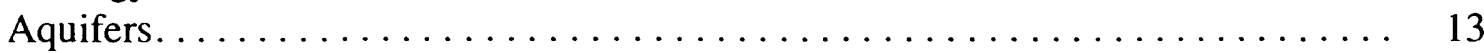

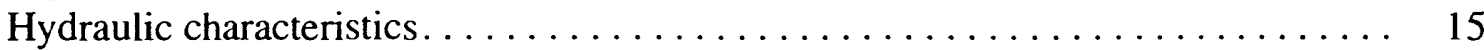

Transmissivity and hydraulic conductivity ............... 15

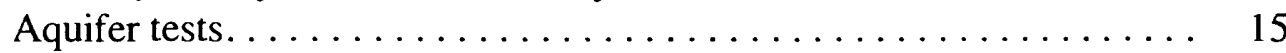

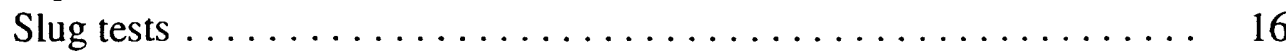

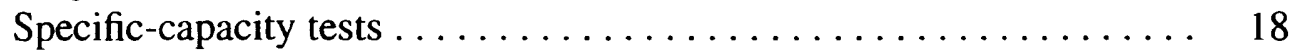

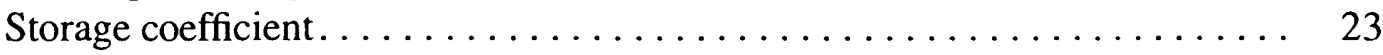

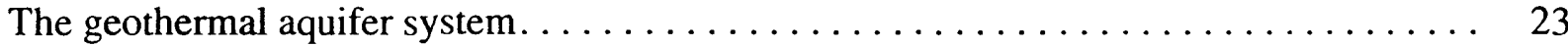

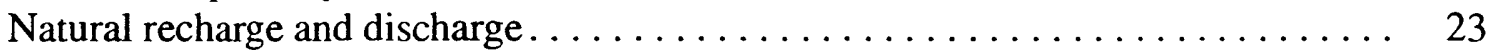

Ground-water development. . . . . . . . . . . . . . . . . . . 26

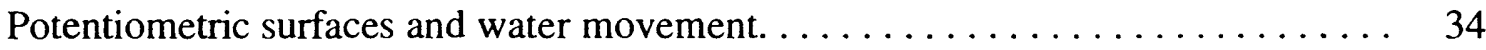

Conceptualization of the geothermal aquifer system $\ldots \ldots \ldots \ldots \ldots \ldots \ldots$

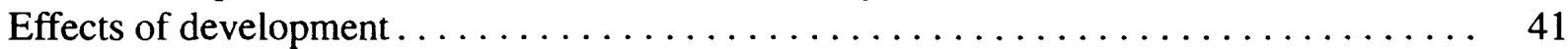

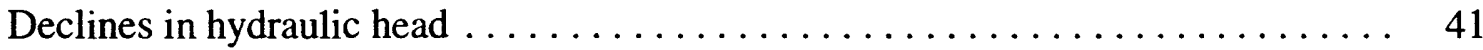

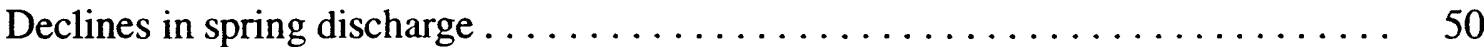

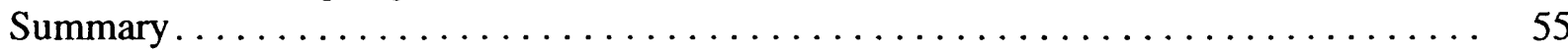

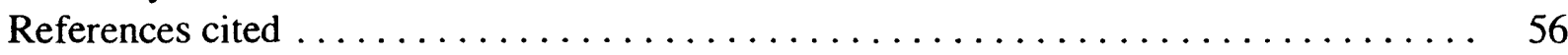

\section{FIGURES}

1. Map showing location of study area $\ldots \ldots \ldots \ldots \ldots \ldots \ldots \ldots \ldots \ldots$

2. Map showing generalized geology of the Bruneau River drainage basin and adjacent areas $(\mathrm{A})$ and the Bruneau study area $(\mathrm{B}) \ldots \ldots \ldots \ldots \ldots$

3. Geologic sections............................ 10

4. Map showing thickness of sedimentary rocks (A) and altitude of base of

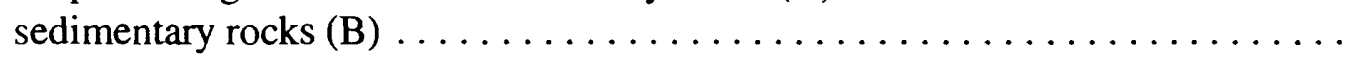

5. Graphs showing application of method of Cooper and others (1967) to analysis of slug tests in test holes 8S-6E-3BDC2 and 8S-6E-3BDC3 .

. Graphs showing application of method of Kipp (1985) to analysis of slug tests in test holes 7S-6E-29BBA1, 8S-6E-3BDC1, and 8S-6E-4DCD1 . . . . . . . 19

7. Map showing location of irrigation wells and year drilled $\ldots \ldots \ldots \ldots 27$ 
FIGURES-Continued

8-12. Graphs showing:

8. Cumulative number of irrigation wells drilled in the Bruneau area,

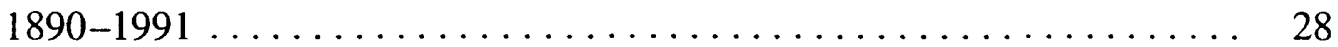

9. Distribution of annual discharge from irrigation wells in the Bruneau

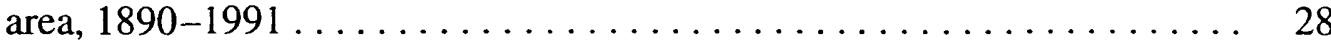

10. Discharge and percent of total from irrigation wells at various distances from Indian Bathtub Spring (8S-6E-3BDD1S), 1978-91 . . . . . . . 31

11. Average 1962-91 and monthly precipitation and monthly well discharge estimated from consumptive use and from electrical power data in the

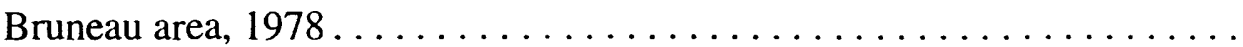

12. Relations among precipitation, water level in test hole $8 \mathrm{~S}-6 \mathrm{E}-3 \mathrm{BDC1}$, discharge from Indian Bathtub Spring (8S-6E-3BDD1S), and estimated monthly discharge from irrigation wells, $1990-91 \ldots \ldots \ldots \ldots \ldots$

13. Map showing potentiometric surfaces and directions of water movement in sedimentary-rock and volcanic-rock aquifers, spring $1989 \ldots \ldots \ldots \ldots \ldots \ldots$

14. Diagrams showing conceptualization of the regional geothermal aquifer system in the Bruneau study area. . . . . . . . . . . . . . . . . . . . .

15-17. Hydrographs for:

15. Wells completed in the sedimentary-rock aquifer $\ldots \ldots \ldots \ldots \ldots \ldots . \ldots 42$

16. Wells completed in the volcanic-rock aquifer . . . . . . . . . . . 43

17. Test holes near Indian Bathtub Spring, April 1990 through April 1992. . . 47

18. Graph showing discharge of Indian Bathtub and Pence Hot Springs and total annual well discharge in the Bruneau study area, 1890-1991 . . . . . . . . . 49

19. Hydrographs for test hole 8S-6E-3BDC1 and spring discharge at four sites . . . 51

20. Graphs showing relation between water level in test hole $8 \mathrm{~S}-6 \mathrm{E}-3 \mathrm{BDC} 1$ and

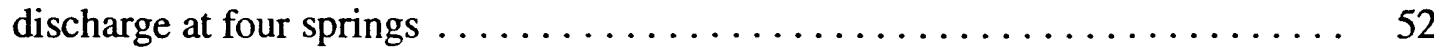

21. Graphs showing relation between hydraulic head and discharge at Indian Bathtub Spring, lower and vent sites.

\section{TABLES}

1. Selected wells in the regional geothermal aquifer system used to represent confining conditions in the Bruneau River drainage basin . . . . . . . . . 14

2. Specific-capacity and construction data for wells in the Bruneau study area . . . 20

3. Estimated transmissivity and hydraulic conductivity from specific-capacity tests for wells in the Bruneau study area . . . . . . . . . . . . . . 22

4. Spring discharges in the Bruneau study area prior to extensive ground-water development.

5. Areal distribution of discharge from irrigation wells in the Bruneau study area, 1922, 1954, and 1978-91, at specified radial distances from Indian Bathtub Spring (8S-6E-3BDD1S) . . . . . . . . . . . . . . . . . .

6. Monthly consumptive use estimates based on evapotranspiration by alfalfa at Bruneau . . . . . . . . . . . . . . . . . . . . . . . . . . . . . . 
TABLES-Continued

7. Water-level measurements in selected wells, Bruneau study area, spring 1989 . $\quad 37$

8. Hydraulic heads and potential for vertical ground-water movement in paired wells . . . . . . . . . . . . . . . . . . . . . . .

9. Spring 1979, 1989, and 1992 hydraulic head measurements and head declines since 1979 at selected wells in the Bruneau study area . . . . . . . . . . . .

\section{CONVERSION FACTORS AND VERTICAL DATUM}

\begin{tabular}{|c|c|c|}
\hline Multiply & By & To obtain \\
\hline acre & 0.004047 & square kilometer \\
\hline acre-foot (acre-ft) & 1,233 & cubic meter \\
\hline acre-foot per year (acre-ft/yr) & 1,233 & cubic meter per year \\
\hline calorie per second $(\mathrm{cal} / \mathrm{s})$ & 4.184 & watt \\
\hline cubic foot per day $\left(\mathrm{ft}^{3} / \mathrm{d}\right)$ & 0.02832 & cubic meter per day \\
\hline cubic foot per second $\left(\mathrm{ft}^{3} / \mathrm{s}\right)$ & 0.02832 & cubic meter per second \\
\hline cubic mile $\left(\mathrm{mi}^{3}\right)$ & 4.168 & cubic kilometer \\
\hline foot $(f t)$ & 0.3048 & meter \\
\hline foot per day ${ }^{1}(\mathrm{ft} / \mathrm{d})$ & 0.3048 & meter per day \\
\hline foot per mile (ft/mi) & 0.1894 & meter per kilometer \\
\hline foot per year (ft/yr) & 0.3048 & meter per year \\
\hline foot squared per day ${ }^{2}\left(\mathrm{ft}^{2} / \mathrm{d}\right)$ & 0.09290 & meter squared per day \\
\hline gallon per minute $(\mathrm{gal} / \mathrm{min})$ & 0.003785 & cubic meter per minute \\
\hline gallon per minute per foot $[(\mathrm{gal} / \mathrm{min}) / \mathrm{ft}]$ & 0.2070 & liter per second per meter \\
\hline inch (in.) & 25.4 & millimeter \\
\hline inch per year (in/yr) & 25.4 & millimeter per year \\
\hline kilowatthour (kWh) & $3,600,000$ & joule \\
\hline mile (mi) & 1.609 & kilometer \\
\hline picocurie per liter (pCi/L) & 0.037 & becquerel per liter \\
\hline square mile $\left(\mathrm{mi}^{2}\right)$ & 2.590 & square kilometer \\
\hline
\end{tabular}

Temperature in degrees Fahrenheit $\left({ }^{\circ} \mathrm{F}\right)$ can be converted to degrees Celsius $\left({ }^{\circ} \mathrm{C}\right)$ as follows:

$$
{ }^{\circ} \mathrm{C}=5 / 9\left({ }^{\circ} \mathrm{F}-32\right)
$$

Sea level: In this report, "sea level" refers to the National Geodetic Vertical Datum of 1929-a geodetic datum derived from a general adjustment of the first-order level nets of the United States and Canada, formerly called Sea Level Datum of 1929.

\footnotetext{
${ }^{1}$ The standard unit for hydraulic conductivity is cubic foot per day per square foot. This mathematical expression reduces to foot per day, which is used in this report.

${ }^{2}$ The standard unit for transmissivity is cubic foot per day per square foot times foot of aquifer thickness. This mathematical expression reduces to foot squared per day, which is used in this report.
} 


\title{
Effects of Well Discharges on Hydraulic Heads in and Spring Discharges from the Geothermal Aquifer System in the Bruneau Area, Owyhee County, Southwestern Idaho
}

\author{
By Charles Berenbrock
}

\section{Abstract}

Demand for ground water in the 600square-mile Bruneau study area has increased since 1954 because of agricultural development. Declining flow at Indian Bathtub Spring is adversely affecting a unique species of snail that inhabits the spring.

The Bruneau study area is underlain by sedimentary and volcanic rocks that form a regional geothermal aquifer. Sedimentary rocks range in thickness from zero in the southern part of the study area to more than 3,000 feet in the northeastern corner. Volcanic rocks underlie the entire study area and extend southward to the Jarbidge Mountains. In the central part of the study area, the volcanic rocks are probably 2,000 to 3,000 feet thick. For purposes of study, the regional geothermal aquifer system was divided into sedimentaryand volcanic-rock aquifers.

Ground water flows northward through the volcanic-rock aquifer to the sedimentaryrock aquifer, from areas of recharge along the Jarbidge and Owyhee Mountains into the study area, where it is discharged as spring flow or leaves the study area as underflow. Prior to extensive ground-water development, about 10,100 acre-feet was discharged by springs.

Ground-water discharge from wells began in the late 1890's. From the 1890's through 1951, annual discharge was less than 10,000 acre-feet. From 1952 to 1978, annual discharge increased to about 40,600 acre-feet. During 1978-91, well discharge declined from the maximum of 49,900 acre-feet in 1981 to
34,700 acre-feet in 1991. Through 1991, nearly $1,400,000$ acre-feet of ground water discharged from wells; about 546,000 acre-feet discharged from 1978 through 1991. Most pumped water is from the volcanic-rock aquifer.

Ground-water development since the mid-1890's locally has modified the direction of water movement in both the sedimentaryand volcanic-rock aquifers. In 1989, ground water moved toward four cones of depression created by pumping - two in the northern part of the study area are in the sedimentary-rock aquifer, two in the southern part are in the volcanic-rock aquifer. Pumping has caused hydraulic heads in the volcanic-rock aquifer to decline more than 30 feet in much of the area and at least 70 feet in one well. About 1 mile from Indian Bathtub Spring, the water level in one well declined about 10 feet during 1979-92, or about 0.7 feet per year.

Within the past 25 years, discharge from monitored springs along Hot Creek and the Bruneau River has declined, most notably from Indian Bathtub Spring. Discharge from Indian Bathtub Spring in 1964 was about 2,400 gallons per minute, and by the summer of 1989, discharge was zero. Discharge began to decline in the mid-1960's when the rate of increase in pumpage accelerated. In contrast, discharge from Pence Hot Spring has ranged from about 700 gallons per minute to about 1,100 gallons per minute.

Changes in discharge from monitored springs corresponded with changes in hydraulic head, which fluctuates seasonally, and are 
substantially less in late summer than in the spring. A hydraulic head/spring discharge relation was developed for two sites at Indian Bathtub Spring and a nearby test hole. The relation for Indian Bathtub Spring indicated that a spring discharge of 2,400 gallons per minute would relate to a hydraulic head of about 2,708 feet at the spring, which is about 34 feet higher than the head at zero spring discharge.

\section{INTRODUCTION}

Bruneau, Little, and Sugar Valleys, within the 600-mi ${ }^{2}$ Bruneau study area (fig. 1) in north-central Owyhee County, have undergone extensive agriculturaI development since the turn of the century. Additional water is needed for irrigation (due to phasing out of "set aside" irrigated lands) in those valleys. A geohydrologic study of the same general area by Littleton and Crosthwaite (1957) indicated that available surface water was inadequate for all irrigable lands. They also noted that the regional geothermal aquifer is perhaps the most promising source for additional water. In 1980, about 25,000 acres in the study area were irrigated with surface water and about 20,000 acres were irrigated with ground water (Lindholm and Goodell, 1986). Young and others (1979, p. 15) estimated that in 1978, about 39,000 acre-ft of ground water was discharged from wells in the study area. Pumping of ground water for irrigation has lowered hydraulic heads throughout the area. Consequently, discharge from monitored geothermal springs along the Bruneau River and Hot Creek is declining, with intermittent flow from Indian Bathtub Spring. Young and others (1990) showed that Indian Bathtub Spring did not flow from July through October 1989 and from July through September 1990.

The Bruneau Hot Springs snail is present in springs along Hot Creek and the Bruneau River in Owyhee County. Within the past 25 years, flows from monitored springs have declined; this decline may have restricted the snail's habitat. Several public agencies, the general public, and Idaho's congressional delegation have become concerned about the continued existence of the snail. The
U.S. Fish and Wildlife Service (USFWS) is concerned that declines in spring flow might cause the snail's extinction.

\section{Purpose and Scope}

In 1987, the USFWS entered into a cooperative agreement with the U.S. Geological Survey (USGS) to develop and implement a three-phase ground-water study of the Bruneau area. This study focused on the hydrology of the regional geothermal system and the hot springs. During the first phase of the study, completed in 1989 (Young and Parliman, 1989), the hydrologic data base was updated and evaluated and a ground-water and spring-monitoring program was implemented in the Indian Bathtub study area, which occupies about $145 \mathrm{mi}^{2}$ of the larger Bruneau study area. The second phase, completed in 1990 (Young and others, 1990), resulted in the drilling of eight test holes at four sites near the Indian Bathtub Spring (fig. 1). These test holes were designed to provide a better understanding of the relation between hydraulic heads and spring discharge. The purpose of the third phase of the study, described in this report, is to determine the cause or causes of declining flow at Indian Bathtub Spring.

The third phase, completed in 1992, included (1) evaluating all available information about the regional geothermal aquifer system; (2) describing the geohydrology of the Bruneau study area, including ground-water recharge, discharge, movement, and hydraulic head; (3) describing vertical variations in hydraulic head; and (4) determining the effects of discharge from wells on hydraulic heads and spring flows in the study area.

\section{Description of the Study Area}

The Bruneau study area is near the southern margin of the western Snake River Plain, about $65 \mathrm{mi}$ southeast of Boise (fig. 1). The study area includes the Indian Bathtub area and extends north from about $42^{\circ} 45^{\prime}$ latitude to the Snake River, east from the drainage divide between Shoofly Creek and Little Jacks Creek to the drainage divide between the Bruneau River and Sailor Creek-an area of about $600 \mathrm{mi}^{2}$. The study area includes 

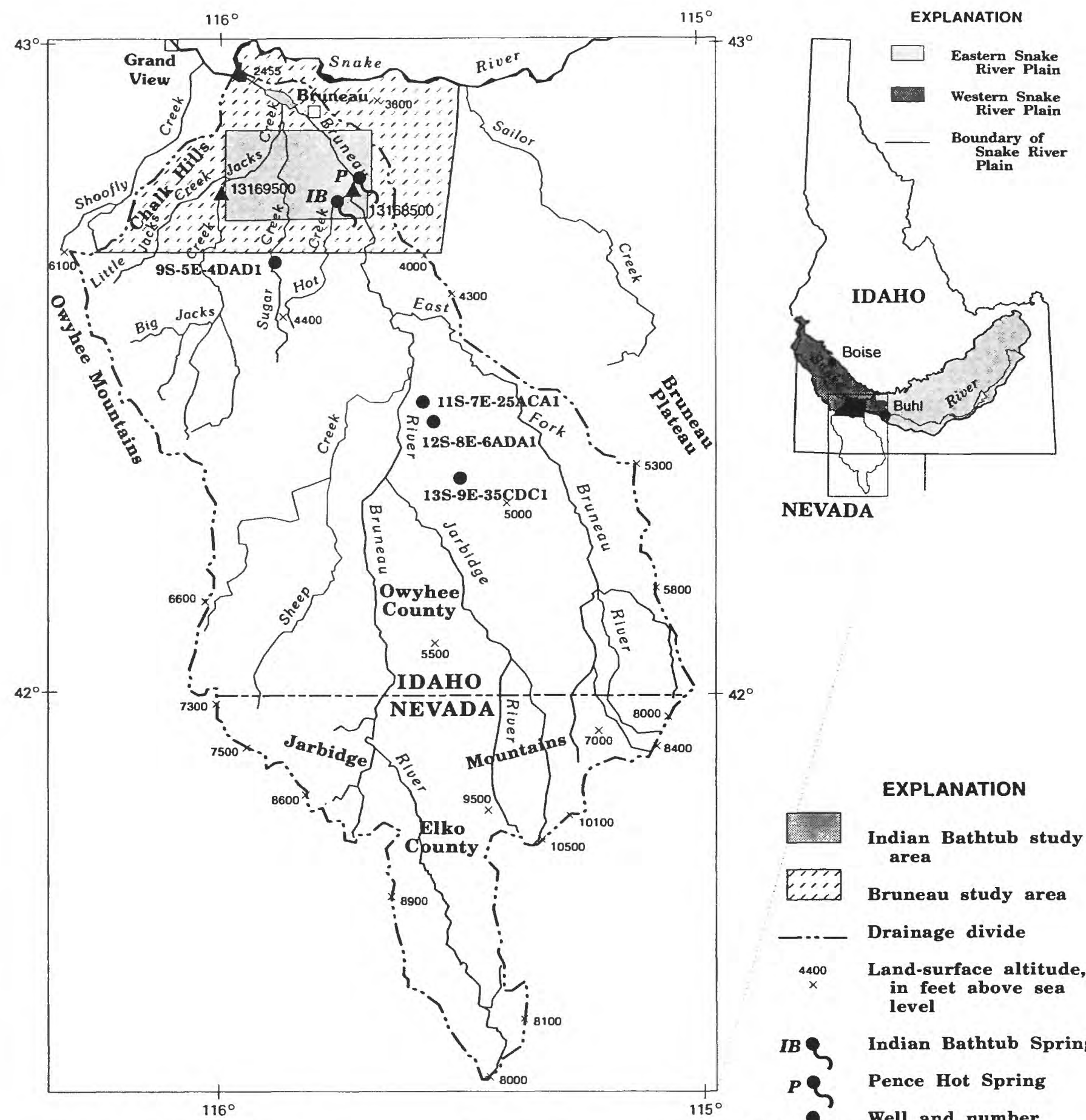

Base from U.S. Geological Survey 1:1,000,000 maps
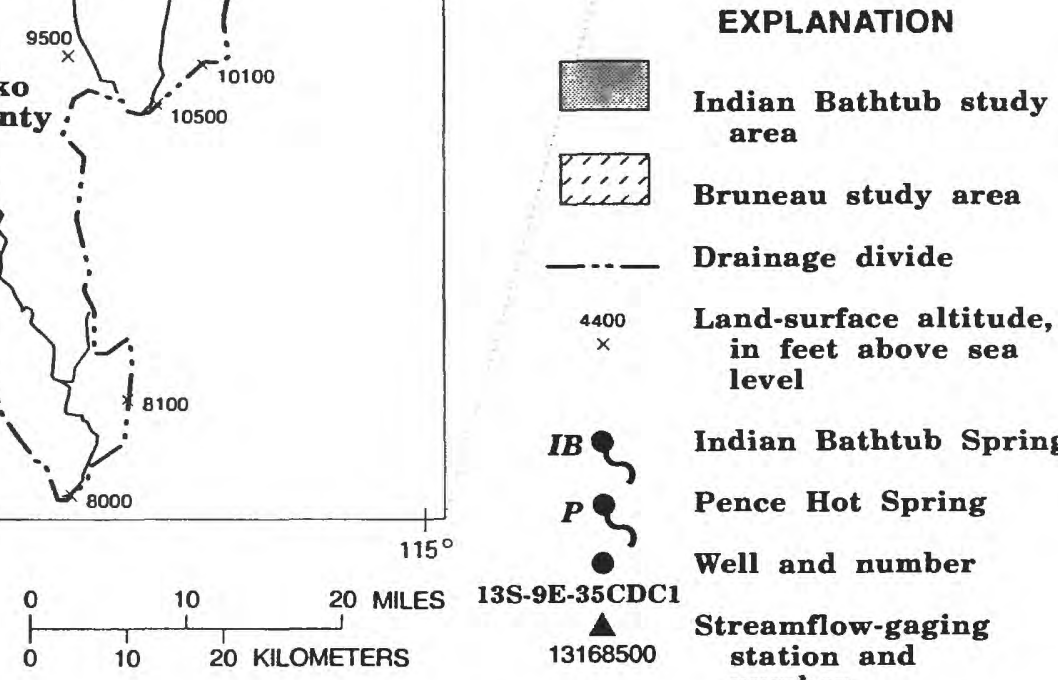

IB Indian Bathtub Spring

$P Q$ Pence Hot Spring

-Well and number

13168500

Streamflow-gaging
station and number

Figure 1. Location of study area. 
Bruneau, Little (includes valleys of Little and Big Jacks Creeks), and Sugar Valleys, which are separated by plateaus several hundred feet higher than the valley floors and included streams.

To understand the hydrology of the Indian Bathtub area, it is necessary to determine its relation to a larger hydrologic unit, the Bruneau River drainage basin (fig. 1). The basin includes the Bruneau study area and is bounded on the south by the Jarbidge Mountains, on the west by the Owyhee Mountains and the Chalk Hills, on the north by the Snake River, and on the east by the Bruneau plateau.

The study area has an arid climate. Average annual precipitation on valley floors is less than 10 in. and the average annual air temperature is about $50^{\circ} \mathrm{F}\left(10^{\circ} \mathrm{C}\right)$. Rainfall is infrequent during the summer; most precipitation (which includes snowfall) is from October through March. Summers are characterized by hot days (average daily maximum temperature is $90^{\circ} \mathrm{F}$, or $32^{\circ} \mathrm{C}$ ) and warm nights (average daily minimum temperature is $54^{\circ} \mathrm{F}$, or $12^{\circ} \mathrm{C}$ ); winters are characterized by cool days (average daily maximum temperature is $43^{\circ} \mathrm{F}$, or $6^{\circ} \mathrm{C}$ ) and cold nights (average daily minimum temperature is $24^{\circ} \mathrm{F}$, or $-4^{\circ} \mathrm{C}$ ).

The Bruneau River drainage area has a predominantly rural population dependent on irrigated agriculture. The city of Bruneau, with a 1990 population of about 300 people, covers several square miles in the northern part of the area and is the largest community.

Most of the Bruneau River drainage area is Federal land leased for grazing under the jurisdiction of the U.S. Bureau of Land Management (BLM). Bruneau, Little, and Sugar Valleys have been irrigated extensively since the turn of the century, whereas intervening plateaus are undeveloped desert. The main crops are hay and alfalfa, associated with the raising of cattle; corn and beans are also grown in Little and Sugar Valleys. Water for irrigation is obtained from streams and from flowing and pumped wells.

Perennial and ephemeral streams drain the study area. The principal drainage is the Bruneau River, a perennial stream that heads in the Jarbidge Mountains and flows northward across the plateaus in deeply incised canyons to the Snake River. Many streams in the study area are ephemeral and flow only in response to rainstorms or spring run- off; included are Big Jacks, Browns, Deer Heaven, Hot, Little Jacks, and Sugar Creeks. Springs discharge directly to some creeks, like Hot Creek, but in the last several years, some monitored springs have not flowed during the summer months.

\section{Previous Investigations}

Early studies of ground-water resources in the Bruneau River drainage area were done by Russell (1903), Stearns (1922), Piper (1924), and Stearns and others (1937). Their reports focus primarily on the artesian conditions. Piper (1924) was the first to estimate the annual withdrawal of ground water from wells. In 1954, Littleton and Crosthwaite (1957) reexamined ground-water resources in the study area and estimated the annual withdrawal from wells. They suggested that further development of the regional geothermal system was possible. Ralston and Chapman (1969) studied ground-water conditions and availability in northern Owyhee County.

More recent ground-water investigations in the Bruneau River drainage area were directed toward geothermal resource assessment. Historical data from geothermal wells and springs in Idaho were summarized by Ross (1971). Young and Mitchell (1973) inventoried and sampled 124 geothermal wells and springs in Idaho for chemical analyses ( 6 in the Bruneau area) and suggested future geothermal studies in 23 areas of the State, including the Bruneau-Grand View area. Areas for study were selected on the basis of estimated aquifer temperatures greater than $140^{\circ} \mathrm{C}$. On the basis of the above recommendations, Young and Whitehead (1975) inventoried and sampled 94 wells and springs in the Bruneau-Grand View area to assess the geothermal system and its probable sources of recharge. They also described the areal extent of the geothermal system on the basis of geological and geophysical evidence. Rightmire and others (1976) used isotopic and geochemical analyses of water from springs and wells in the geothermal system to determine possible sources of recharge. They also indicated that water-level declines since 1954 continued during the 1970's because ground-water withdrawals exceeded recharge. Renner and others (1975) estimated stored heat in the geothermal system on the basis of 
a reservoir temperature of $145^{\circ} \mathrm{C}$ and a reservoir volume of 1,300 $\mathrm{mi}^{3}$. Brook and others (1979) estimated the stored heat on the basis of a reservoir temperature of $107^{\circ} \mathrm{C}$ and a reservoir volume of $439 \mathrm{mi}^{3}$. Young and others (1979) estimated that the discharge from springs and flowing and pumped wells in 1978 was about 50,500 acre-ft. Young and Lewis (1982) developed a conceptual model of the geothermal system and speculated that the recharge area lies somewhere to the south, probably in the Jarbidge and Owyhee Mountains. Using a heat balance equation, they estimated that 29,000 acre-ft of ground water per year is recharged and 18,000 acre-ft of ground water per year is discharged by underflow from the geothermal system from the Idaho-Oregon State line to Buhl (Young and Lewis, 1982, p. 16).

Gemperle (1988) described the regional geothermal aquifer system and the overlying coldwater aquifer. He also identified data needs and proposed ways to optimally manage ground-water resources in the Bruneau-Grand View area. Young and Parliman (1989) collected information on well and spring locations, well construction, and hydraulic head. Water samples from 33 geothermal wells and 5 springs were collected for chemical and isotopic analysis. Young and others (1990) presented geologic and hydrologic data collected during January 1989 through September 1990 from eight test holes drilled near Indian Bathtub Spring and from selected geothermal wells and springs in and around the Indian Bathtub area. At three of the sites, piezometers were installed at different depths to determine changes in hydraulic head with changes in depth. At two sites, piezometers were installed at the same altitude as a nearby spring to enable monitoring of the zone within the regional geothermal aquifer system that controls the spring discharge. Water samples were collected from each test hole to aid in understanding the vertical variations in water quality. Their report includes completion, lithologic, and gamma logs for the test holes; hydrographs of hydraulic head and spring discharge; and chemical and isotopic analyses of water from six of the test holes.

A Regional Aquifer-System Analysis (RASA) of the 15,600-mi² Snake River Plain began in October 1979. The main purposes of the study were to refine knowledge of regional ground- water-flow systems, determine effects of conjunctive use of ground and surface water, and describe ground-water chemistry (Lindholm, 1981). Interpretive RASA reports that include the Bruneau study area are: (1) a regional water-table map and description of the ground-water-flow system (Lindholm and others, 1983 and 1988); (2) a description of the geohydrologic framework (Whitehead, 1986 and 1992); (3) water budgets and streamflow in the Snake River and groundwater budgets for the Snake River Plain (Kjelstrom, 1986 and 1992); (4) water use (Bigelow and others, 1987; Goodell, 1988); (5) a map showing irrigated land and other land uses (Lindholm and Goodell, 1986); and (6) results of ground-water-flow modeling of the western Snake River Plain (Newton, 1991). About 300 model cells out of 3,000 active model cells were used to represent the Bruneau study area.

\section{Acknowledgments}

Appreciation is extended to residents in the study area who supplied data and permitted the use and testing of their wells during this investigation. The Idaho Power Company furnished electrical power data for estimation of irrigation pumpage. Particular appreciation is extended to H.W. Young, U.S. Geological Survey, for calculating pumpage using electrical power data and for measuring water levels in and discharge from irrigation wells in the study area. Special thanks are extended to Margaret D. Jenks, Bill Bonnichsen, and Martha M. Godchaux, Idaho Geological Survey, for providing preliminary information concerning geology and faults.

\section{Well- and Spring-Numbering System}

The well- and spring-numbering system used by the U.S. Geological Survey in Idaho (example on next page) indicates the location of wells within the official rectangular subdivision of public lands, with reference to the Boise base line and Meridian. The first two segments of the number designate the township (north or south) and range (east or west). The third segment gives the section num- 
ber; four letters, which indicate the $1 / 4$ section (160-acre tract), 1/4-1/4 section (40-acre tract), $1 / 4-1 / 4-1 / 4$ section (10-acre tract) and, when needed, $1 / 4-1 / 4-1 / 4-1 / 4$ section (21/2-acre tract); and serial number of the well within the tract.

Quarter sections are designated by the letters $A, B, C$, and D in counterclockwise order from the northeast quarter of each section. Forty-acre, 10acre, and $2 \frac{1}{2}$-acre tracts within each quarter section are lettered in the same manner. Well 7S-6E$21 \mathrm{DBC} 1$, for example, is in the $\mathrm{SW}_{1 / 4} \mathrm{NW}_{1 / 4} \mathrm{SE}^{1 / 4}$ sec. 21 , T. 7 S., R. 6 E., and is the first well inventoried in that tract. Springs are designated by the letter " $S$ " following the last numeral; for example, 8S-6E-3BDD1S.

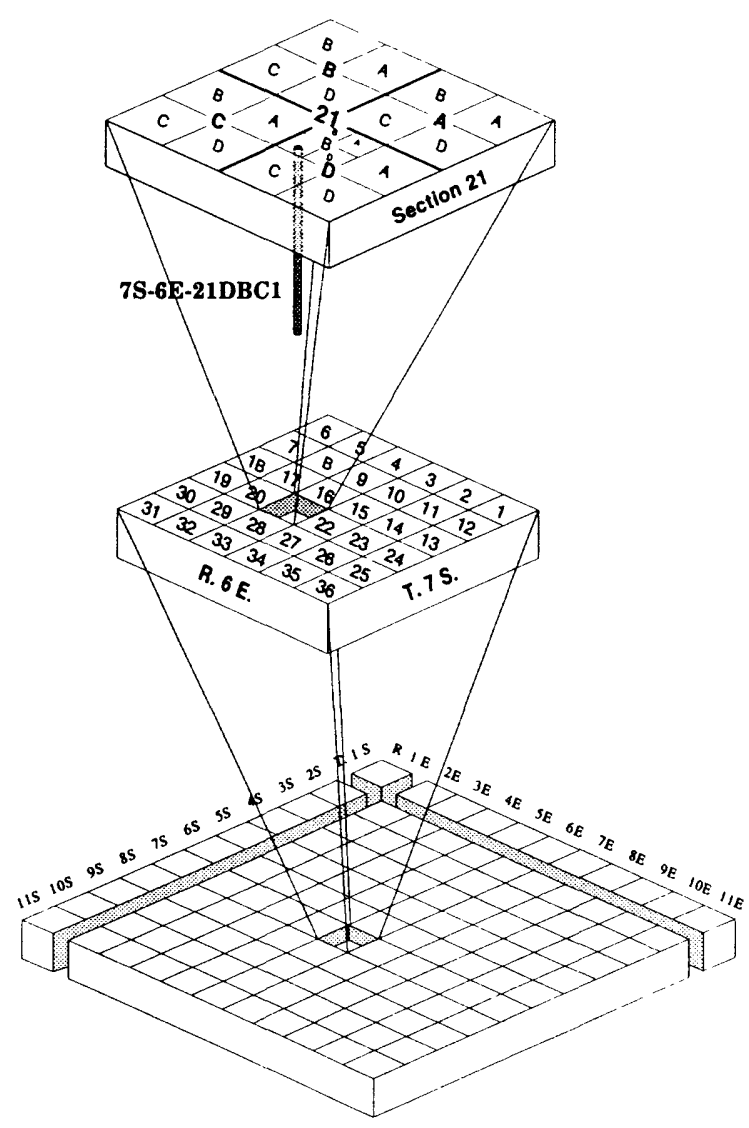

\section{GEOHYDROLOGY}

The development of a conceptual model of the geothermal system in the Bruneau study area involved (1) describing the geology and boundaries of the aquifer system, (2) determining aquifer properties, (3) estimating recharge to and discharge from the aquifer system, and (4) determining the effects of ground-water development on the aquifer system. In addition to reports listed under "Previous Investigations," geology of the study area and surrounding areas is discussed in reports by Malde and Powers (1962), Malde and others (1963), Harper (1963), and Young and Whitehead (1975). Geologic structure is discussed in most of these reports. However, recent geologic mapping in the area indicated that the degree of faulting, especially near Indian Bathtub (M.D. Jenks and others, ldaho Geological Survey, written commun., 1992) is greater than previous investigators thought. Only a brief summary of the geohydrology of the regional geothermal system is included here. The reader is referred to referenced reports for a more complete description of the geohydrology.

\section{Geology}

Rocks in southwestern ldaho and north-central Nevada range in age from Precambrian to Holocene and represent a varied and complex geologic history. Cores of the Owyhee and Jarbidge Mountains, west and south of the study area, are composed of sedimentary and metamorphic rocks of Precambrian and Paleozoic age, intruded by granitic rocks of Mesozoic and Tertiary age. The mountains are as much as $10,500 \mathrm{ft}$ above sea level (fig. 1). Tertiary volcanic rocks ranging in composition from rhyolite to basalt underlie most of the plateaus. Plateaus are from 4,000 to $6,000 \mathrm{ft}$ above sea level and, at high altitudes, are dissected by deeply incised streams. Tertiary and Quaternary rocks and unconsolidated rocks of fluvial and lacustrine origin are present in most of the lower areas and locally are overlain by Quaternary basalt.

For this report, surficial geology was generalized and divided into nine units (Whitehead, 1986, sheet 1). Each unit was delineated on the basis of geohydrologic characteristics. The areal distribution of these units is shown in figure 2.

Pre-Cretaceous (undifferentiated) and granitic rocks crop out only in the Jarbidge Mountains in the Bruneau River drainage area (fig. 2A) and have not been reached by drilling in the Bruneau 
study area. Young and Whitehead (1975, p. 12) indicated that granitic rocks probably form the core of the Owyhee and Jarbidge Mountains and are similar in age and composition to the Idaho batholith. Their thickness is unknown.

Basalt of various ages is present in the Bruneau River drainage area. The older basalt unit, which consists chiefly of Banbury Basalt of Miocene age, is exposed throughout the study area. Although older basalt also is widespread in the subsurface, it was not possible to correlate rock units from the surface to the subsurface (fig. 3). Thickness of the older basalt unit is variable and is unknown in much of the study area. Young and Whitehead (1975) indicated that, in the BruneauGrand View area, the unit ranges in thickness from less than $100 \mathrm{ft}$ to nearly $1,200 \mathrm{ft}$. Ralston and Chapman (1969, p. 17-18) indicated that the Banbury Basalt consists of two types: a relatively fresh, nonaltered basalt and a highly altered basalt. The nonaltered basalt is present mainly in the eastern part of the study area and has well developed columnar and platy horizontal jointing. The altered basalt is present mainly in the western part of the study area, where a high degree of weathering has caused secondary mineralization in fractures and cavities (Ralston and Chapman, 1969, p. 18).

Silicic volcanic rocks of Miocene and Pliocene age, including Idavada Volcanics and other rhyolitic rocks, are exposed on plateaus south of the Snake River (fig. 2) and underlie the entire study area. The predominantly latitic composition of the Idavada Volcanics differentiates them from the other volcanic rocks in this unit. They are mainly thick layers of highly fractured, faulted, and jointed devitrified welded tuff (Young and Whitehead, 1975, p. 11). Idavada Volcanics are probably 2,000 to 3,000 ft thick (Young and Lewis, 1982, p. J4); total thickness of the silicic volcanic rocks is largely unknown but may be as much as $7,000 \mathrm{ft}$ (McIntyre, 1979, p. 7-10).

Basalt of Pleistocene to Miocene age (Idaho Group) crops out in one small area adjacent to the Bruneau River near Indian Bathtub (Whitehead, 1986, sheet 1). Quaternary basalt is exposed only along the Snake River north of Bruneau Valley (fig. 2).
Hereafter, the Tertiary and Quaternary basalt and silicic volcanic rocks are referred to as the volcanic rocks.

Alluvium is of Holocene to Miocene age. Older alluvium (hereafter referred to as sedimentary rocks) of Pleistocene to Miocene age consists of fluvial and lacustrine rocks and includes the Idaho Group. These sedimentary rocks are composed chiefly of unconsolidated, poorly to wellsorted gravel, sand, silt, and clay. The percentage of silt and clay increases toward the Snake River. The sedimentary rocks are predominant in the northern part of the Bruneau River drainage area (fig. 2A). They range in thickness from $0 \mathrm{ft}$, where they abut against basalt or silicic volcanic rocks in the southern part of the Bruneau area to more than $3,000 \mathrm{ft}$ in the northeastern part (fig. 4A). The distribution of the sedimentary rocks was estimated from drillers' logs

(Whitehead, 1986, sheet 2). Thicknesses shown probably are maximum because interbedded basalt and silicic volcanic rocks are included. The altitude of the base of the sedimentary rocks varies, as shown in figure $4 \mathrm{~B}$.

The younger alluvium of Holocene age covers the floors of tributary valleys and the flood plains of main streams, as in Bruneau and Little Valleys (fig. 2B). These sedimentary rocks range in thickness from 0 to about $50 \mathrm{ft}$ (Littleton and Crosthwaite, 1957, p. 167). Windblown rocks of Holocene age consist of a veneer of sand (usually $100 \mathrm{ft}$ or less in thickness). Active sand dunes at Bruneau Dunes State Park in northeastern Owyhee County are included in these rocks.

The study area is an intensively faulted structural depression (Hill, 1963). Geologic and geophysical data indicate that northwest-trending faults are predominant (fig. 2). Young and Whitehead (1975, p. 13 and fig. 4) indicated that several hundred feet of vertical displacement along major faults may be typical. Faulting appears related to tectonic events that formed the present western Snake River Plain (Malde and Powers, 1962) in early Pliocene and Pleistocene time (Young and Lewis, 1982, p. J4). Recently, an older northeast-trending set of faults has been mapped (M.D. Jenks and others, Idaho Geological Survey, written commun., 1992). 


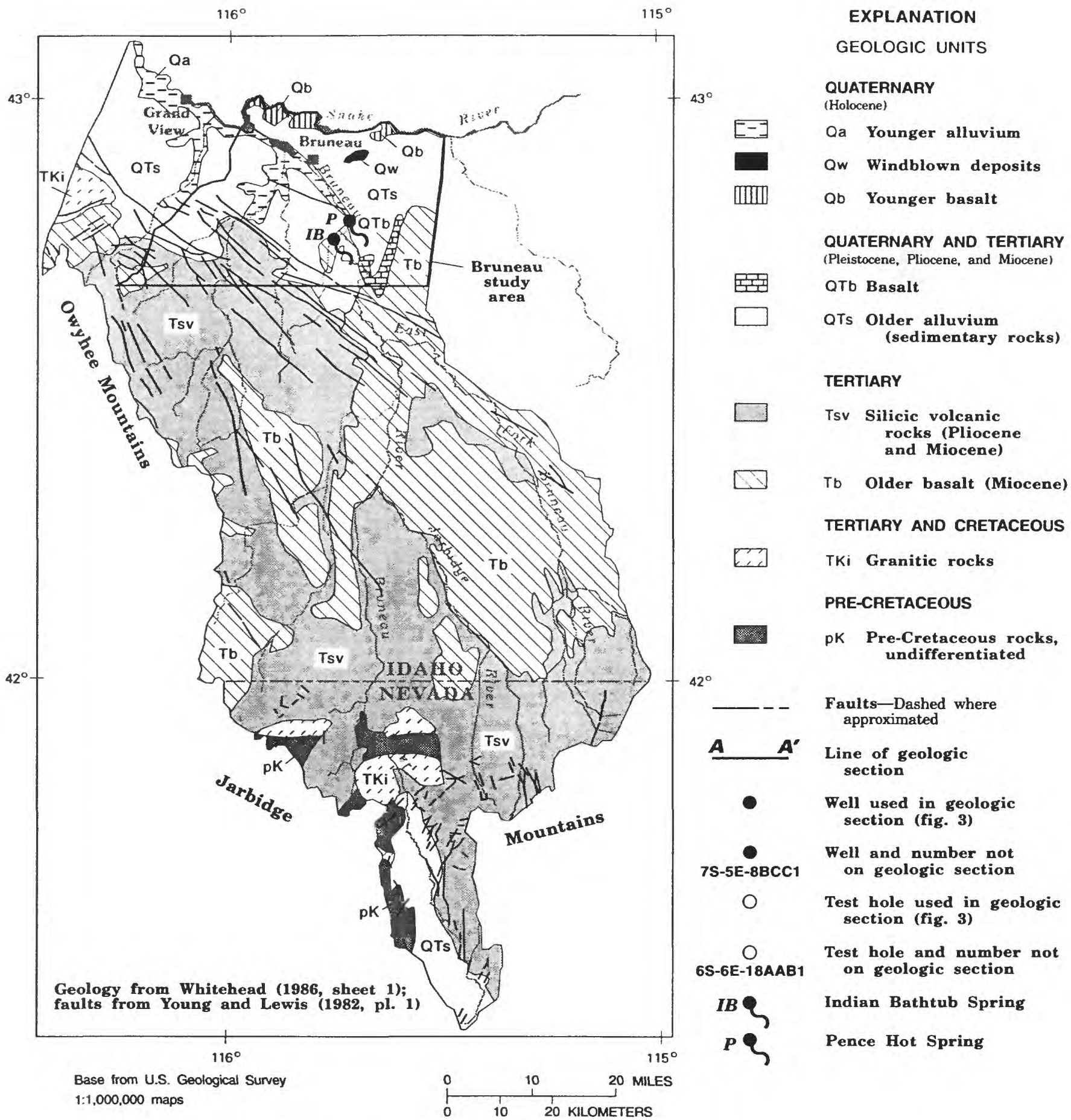

A. Generalized geology of the Bruneau River drainage basin and adjacent areas

Figure 2. Generalized geology of the Bruneau River drainage basin and adjacent areas (A) and the Bruneau study area (B). 


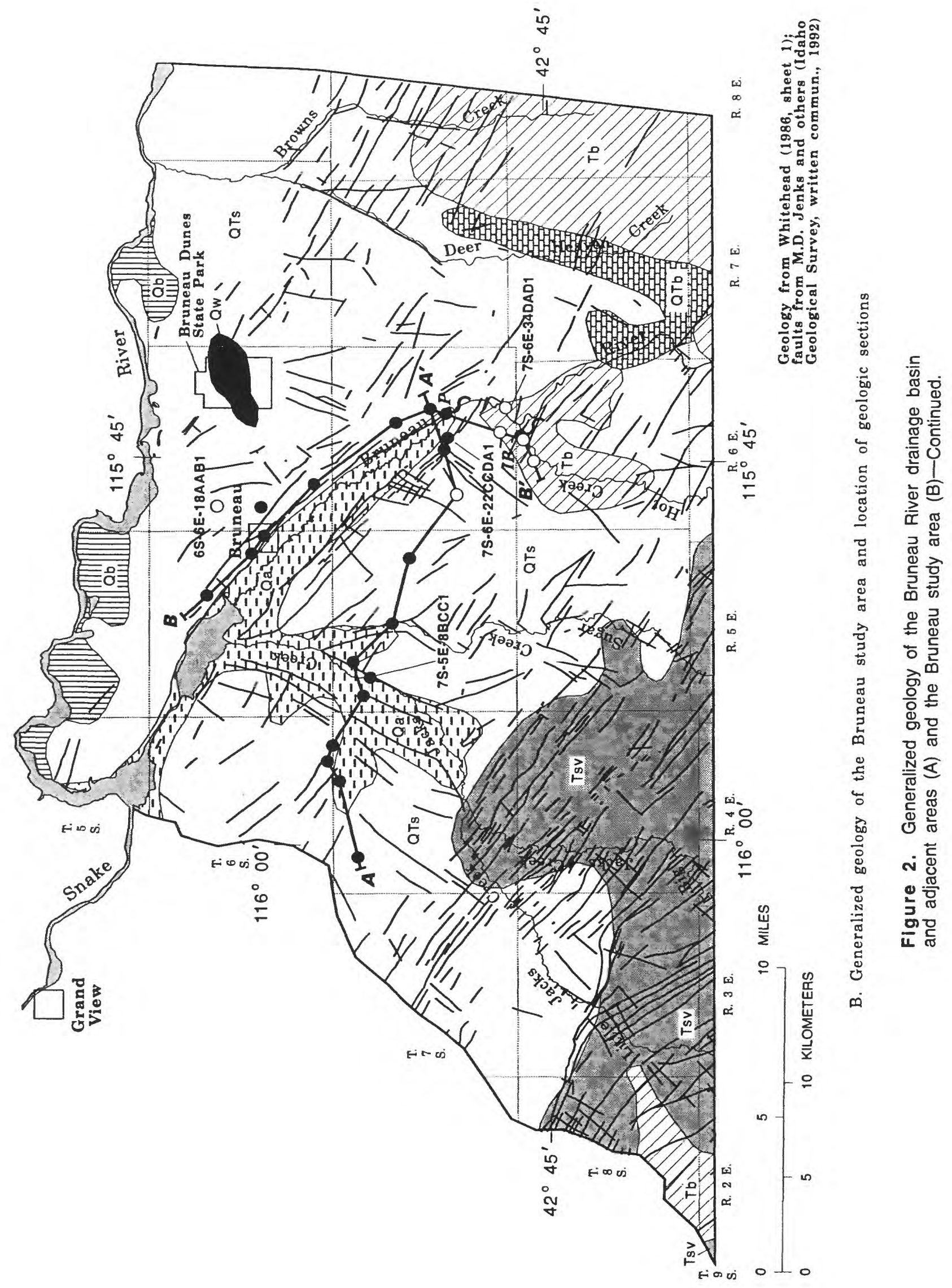




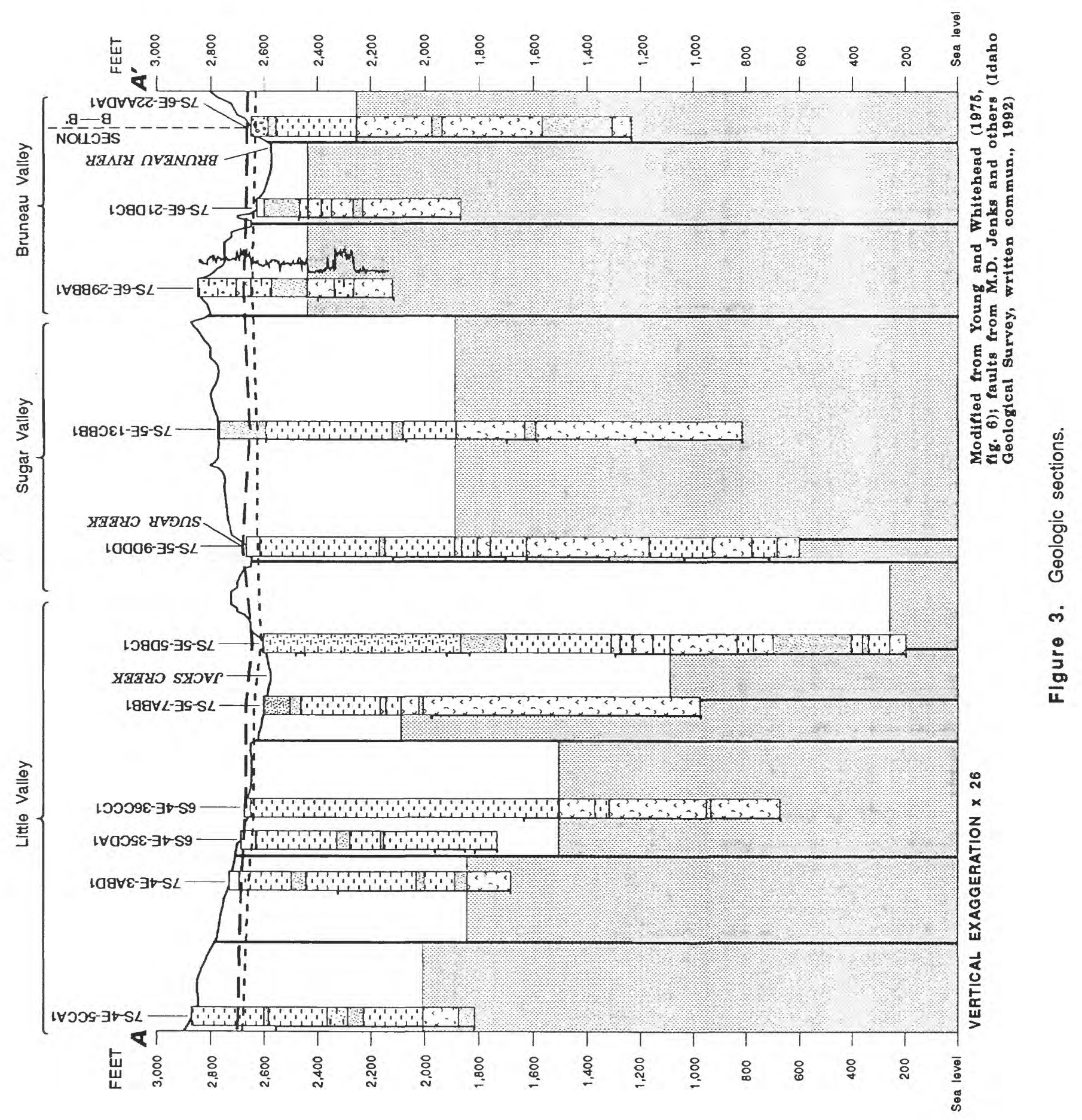



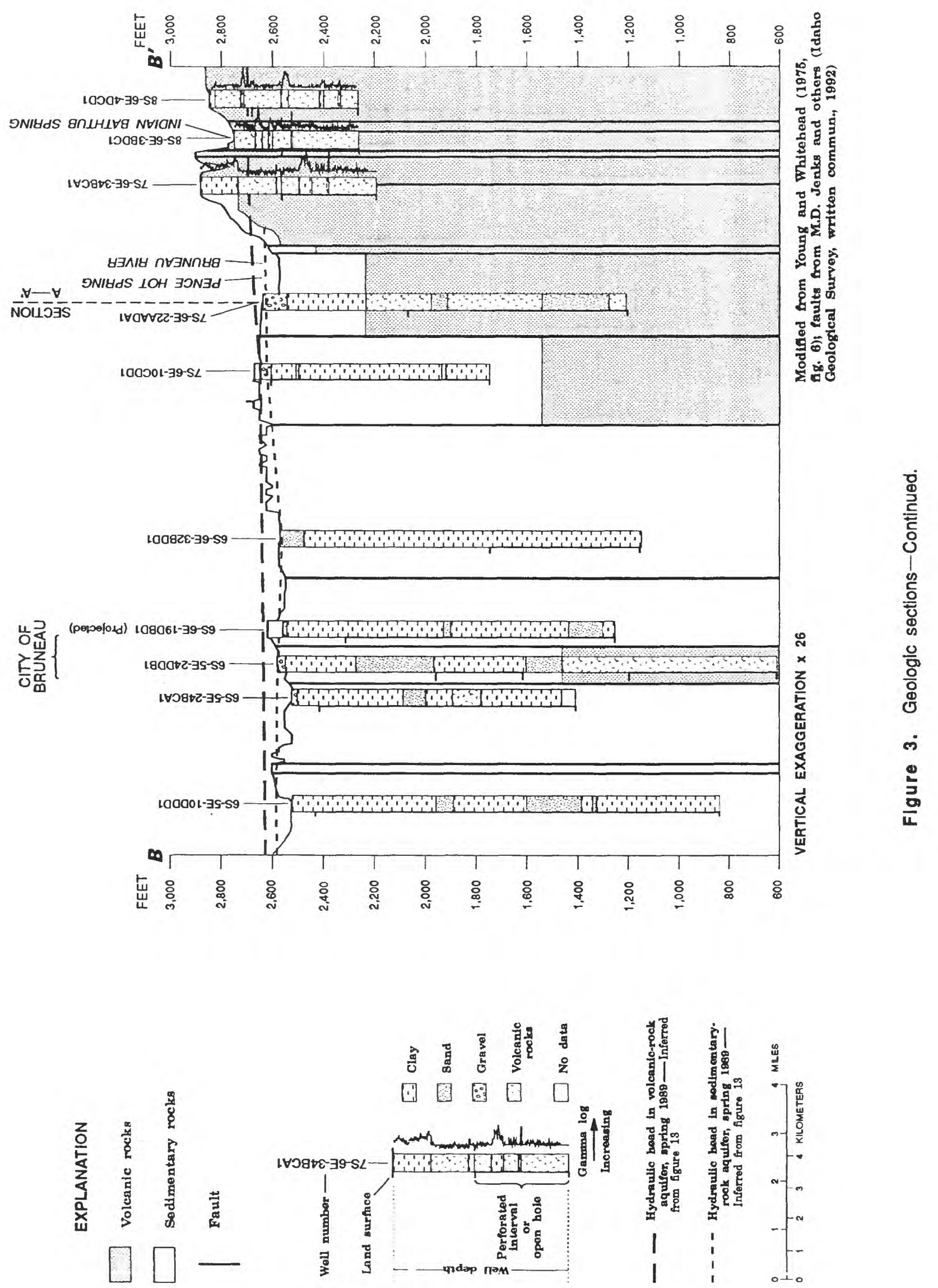
EXPLANATION

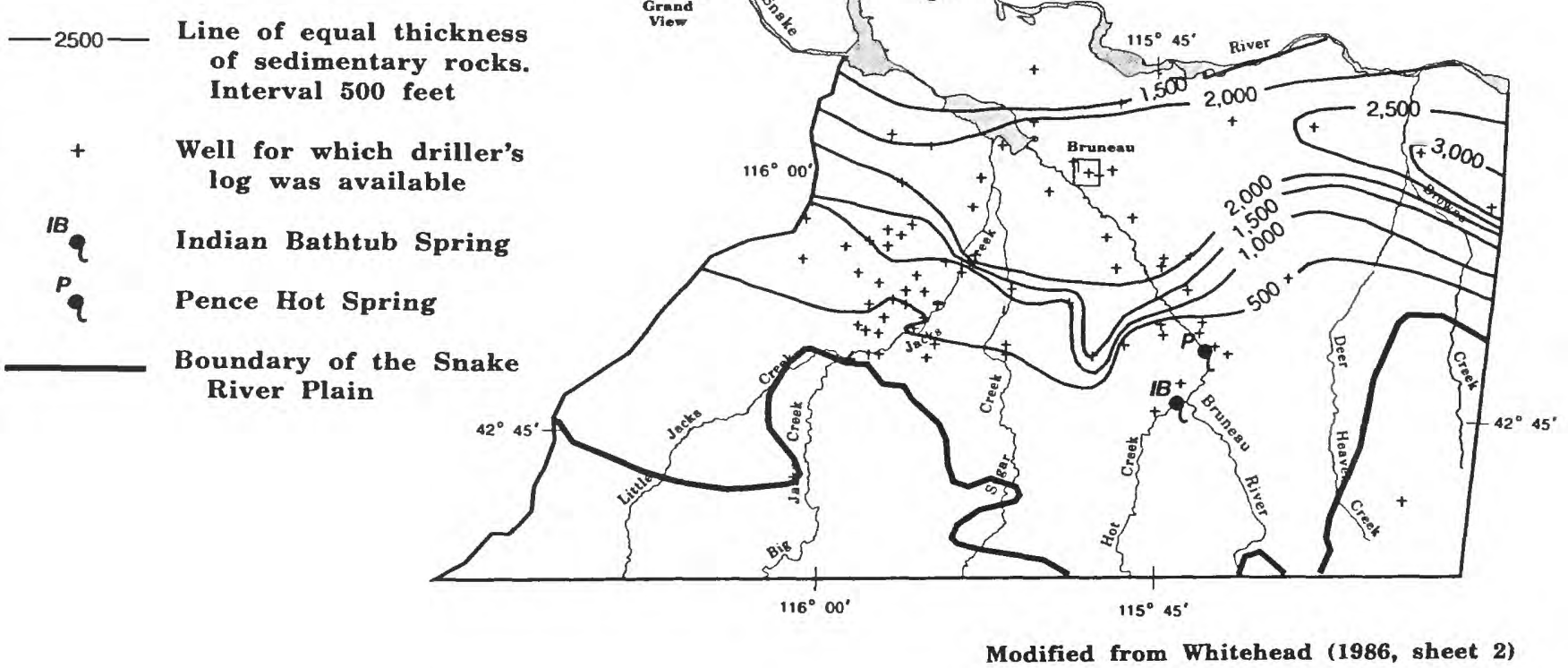

A. Thickness of sedimentary rocks

EXPLANATION

- 500 - Line of equal altitude of base of sedimentary rocks, in feet above sea level. Interval 500 feet.

$+\quad$ Well for which driller's log was available

${ }^{1 B} q$ Indian Bathtub' Spring

P Pence Hot Spring

Boundary of the Snake River Plain
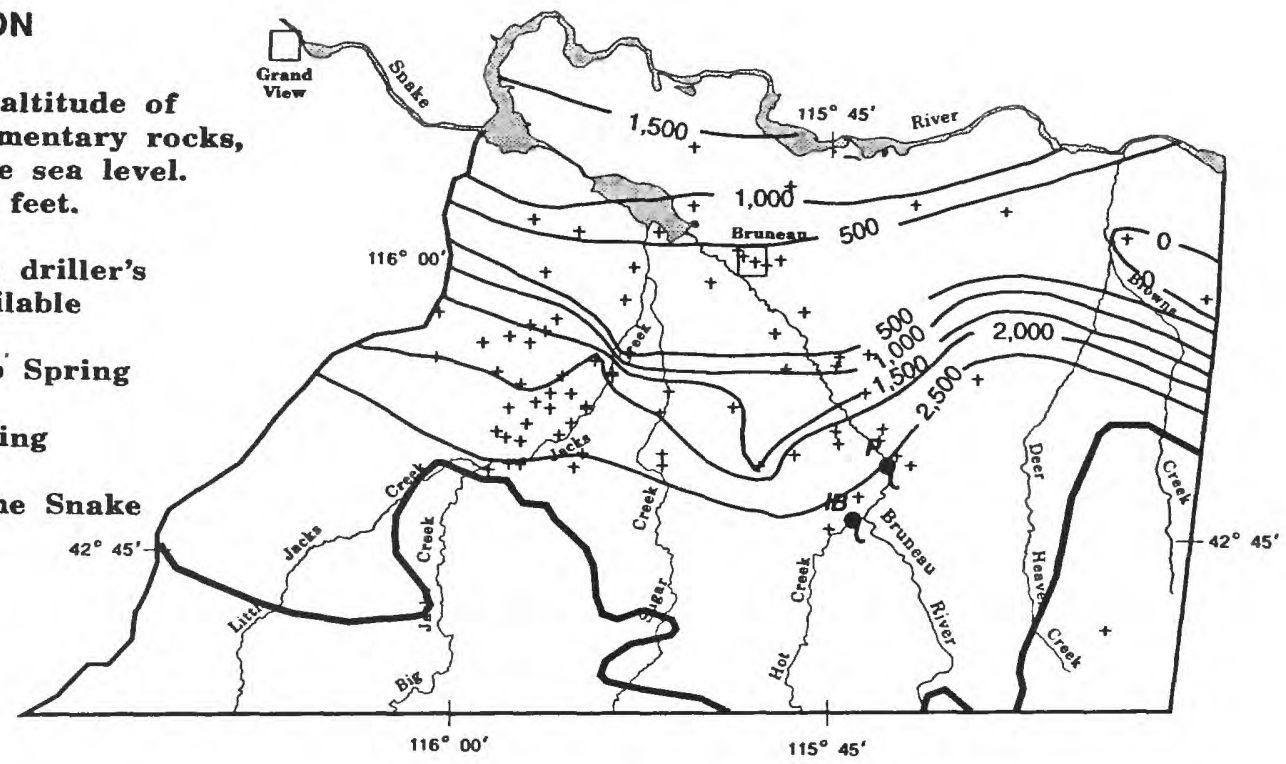

B. Altitude of base of sedimentary rocks

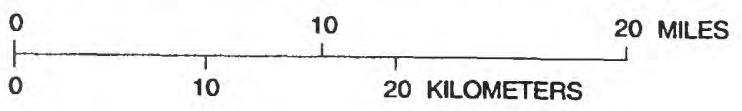

Figure 4. Thickness of sedimentary rocks (A) and altitude of base of sedimentary rocks (B). 


\section{Aquifers}

Geothermal water in the study area is present in pore spaces of sedimentary rocks and in vesicles, fractures, and rubble zones of volcanic rocks. On the basis of lithologic logs from drill holes, Young and Whitehead (1975, p. 13) divided the regional geothermal aquifer system into two main parts - the sedimentary-rock aquifer and the volcanic-rock aquifer. An aquifer can consist of rocks of different types and of different ages that are permeable and hydraulically connected. For this report, the term "aquifer" refers to hydraulically connected volcanic rocks and sedimentary rocks that together compose the regional geothermal aquifer system.

Cold-water and geothermal aquifers are present in the Bruneau study area. The cold-water aquifer is thin (less than $100 \mathrm{ft}$ ) and of small areal extent (alluvium along stream channels, fig. 2). Cold water is unconfined and recharge is from infiltration of precipitation, streamflow, and applied irrigation water. Small quantities of recharge may be from upward-moving geothermal water.

Underlying the cold-water aquifer is a geothermal aquifer. Data are unavailable to adequately define hydrologic relations between the two. Therefore, it is not known whether the coldwater aquifer is perched above or grades into the geothermal aquifer. In 1991, the U.S. Geological Survey (R. Thompson, oral commun., 1992) cored a 1,000-ft test hole about $1 \mathrm{mi}$ north of the city of Bruneau (fig. 2B). Except for the upper few feet, the entire interval tested was predominantly clay. No cold or hot water entered the hole. During test drilling near Indian Bathtub Spring for this study (table 1 and Young and others, 1990), only geothermal water was encountered.

Cold water differs from geothermal water not only in temperature but also in chemical and isotopic composition. Young and Lewis (1982, p. J10$\mathrm{J} 18$ ) reported that cold-water temperatures ranged from $4^{\circ}$ to $15^{\circ} \mathrm{C}$, whereas geothermal water temperatures ranged from $27^{\circ}$ to more than $80^{\circ} \mathrm{C}$. Cold water is generally a calcium bicarbonate type with a dissolved-solids concentration of less than $120 \mathrm{mg} / \mathrm{L}$, whereas geothermal water is generally a sodium carbonate or bicarbonate type with a dissolved-solids concentration of less than $400 \mathrm{mg} / \mathrm{L}$.
Young and Lewis (1982, p. J9-J11) also reported that tritium and delta deuterium in cold-water springs and wells (alluvial aquifer) ranged from 59 to 119 TU (tritium units) and -116 to -128 permil, respectively, whereas tritium in geothermal springs and wells (sedimentary- and volcanic-rock aquifers) was less than 1.9 TU and delta deuterium ranged from -130 to -140 permil. (One TU equals a ${ }^{3} \mathrm{H} / \mathrm{H}$ ratio of about $10^{-18}$, or about $3.2 \times 10^{-18}$ picocuries per liter.) They indicated that, on the basis of tritium analyses, the cold water is less than 20 years old, whereas geothermal water is meteoric in origin and, on the basis of delta deuterium analyses, was recharged during an earlier pluvial period (late Pleistocene). Carbon isotope analyses of geothermal water indicate an apparent age of 18,000 to 25,000 years (Young and Lewis, 1982, p. J16-J17).

The sedimentary-rock aquifer consists of unconsolidated alluvial and lacustrine deposits that partly fill the structural depression in the study area. Some volcanic rocks are interbedded within the sedimentary rocks. Sedimentary rocks underlie about $500 \mathrm{mi}^{2}$ of the study area, or less than oneseventh of the Bruneau River drainage area (fig. 2A). The base of the sedimentary-rock aquifer corresponds to the base of the sedimentary rocks (fig. 3B), and saturated thickness is approximately the thickness of the sedimentary rocks (fig. 3A) minus $100 \mathrm{ft}$ (the approximate thickness of the cold-water aquifer). The sedimentary-rock aquifer is bounded on the south by silicic volcanic rocks and older basalt and on the north by younger basalt (fig. 2A). It is part of a more extensive aquifer in the western Snake River Plain (Newton, 1991, p. 4 -7). The eastern and western boundaries for this study are not based on differences in lithology but follow approximate ground-waterflow lines. The eastern boundary is assumed to be coincident with the topographic divide between Bruneau River and Sailor Creek. The topographic divide approximates a flow line based on the March 1982 potentiometric surface (Moffatt and Jones, 1984, pl. 2). The western boundary is assumed to be coincident with the topographic divide between Shoofly Creek and Little Jacks Creek. The topographic divide approximates a flow line based on the 1979 potentiometric surface (Young and Lewis, 1982, pl. 2). There was no 
significant movement of ground water across these boundaries after about 90 years of pumping.

The sedimentary rocks consist primarily of fine sand, silt, and clay of low permeability (fig. 4). Fine-grained sedimentary rocks confine or partly confine water in coarser grained sedimentary rocks, which are recharged by water from the volcanic-rock aquifer (Young and Whitehead, 1975, p. 44). Yield from wells completed in the sedimentary rocks ranges from a few gallons per minute from silt and clay to several hundred gallons per minute from sand and gravel, depending on the percentage of fine-grained rocks (Young and Whitehead, 1975, p. 9; Whitehead, 1986, sheet 1).

In the southern part of the study area, the volcanic-rock aquifer consists of basalt and silicic volcanic rocks with some interbedded sedimentary. rocks. The volcanic rocks extend southward to the Jarbidge Mountains. The base of the volcanic-rock aquifer is poorly defined and has not been reached by drilling; therefore, saturated thickness is largely unknown. Saturated thickness in the southern part of the study area is approximately the thickness of the volcanic rocks (2,000 to 3,000 ft) minus depth to the top of the volcanic-rock aquifer. Where overlain by the sedimentary-rock aquifer, thickness of the volcanic-rock aquifer is estimated to be about $2,500 \mathrm{ft}$, probably the average thickness of the volcanic rocks. For the purpose of this study, the eastern and western boundaries of the volcanicrock aquifer flow system are assumed to be the same as those of the sedimentary-rock aquifer.

In the northern part of the study area, water in the volcanic rocks is confined by fine-grained sedimentary rocks; in the southern part, water is confined by overlying dense volcanic rocks and finegrained interbeds. In each of the test holes at four sites near Indian Bathtub Spring (Young and others, 1990), water in the hole rose to higher altitudes than first-encountered water during drilling (table 1). This indicates that water in the volcanic rocks is confined. Three wells (11S-7E-25ACA1, 12S-8E-6ADA1, and 13S-9E-35CDC1) about 23 to $35 \mathrm{mi}$ south of Indian Bathtub Spring had higher hydraulic head than first-encountered water during drilling (table 1). Recharge to the volcanic-rock aquifer is chiefly from precipitation in the mountains south and southwest of the study area where rocks are exposed at the surface (Young and Whitehead, 1975, p. 44).

Piper (1924, p. 36-38) indicated that many of the springs in the Bruneau study area are controlled by faults. However, he attributed the control of springs at Indian Bathtub to the exposure of waterbearing rocks at land surface, as in the canyon walls along Hot Creek. Littleton and Crosthwaite

Table 1. Selected wells in the regional geothermal aquifer system used to represent confining conditions in the Bruneau River drainage basin

[Altitude of land surface in feet above sea level. Depth of well, perforated interval or open hole, depth to first-encountered water, and depth to water, in feet below land surface]

\begin{tabular}{|c|c|c|c|c|c|c|c|c|}
\hline Well No. & $\begin{array}{l}\text { Altitude } \\
\text { of land } \\
\text { surface }\end{array}$ & $\begin{array}{c}\text { Depth } \\
\text { of } \\
\text { well }\end{array}$ & $\begin{array}{l}\text { Perforated } \\
\text { interval } \\
\text { or } \\
\text { open hole }\end{array}$ & $\begin{array}{c}\text { Date } \\
\text { of } \\
\text { well } \\
\text { construction }\end{array}$ & $\begin{array}{l}\text { Depth to } \\
\text { first- } \\
\text { encountered } \\
\text { water }\end{array}$ & $\begin{array}{l}\text { Depth } \\
\text { to } \\
\text { water }\end{array}$ & $\begin{array}{c}\text { Date } \\
\text { measured }\end{array}$ & Confining unit \\
\hline \multicolumn{9}{|c|}{ About 23 miles south of Indian Bathtub Spring } \\
\hline 'IIS-7E-25ACAl & 4,345 & 1,400 & $20-1,400$ & $7-\quad-63$ & 1,004 & 842 & 7- $1-63$ & Basalt \\
\hline \multicolumn{9}{|c|}{ About 25 miles south of Indian Bathtub Spring } \\
\hline ' $12 \mathrm{~S}-8 \mathrm{E}-6 \mathrm{ADA} 1$ & 4,450 & 1,400 & $40-1,400$ & 9- $1-63$ & 1,030 & 881 & 9- $1-63$ & Silicic volcanic rocks \\
\hline \multicolumn{9}{|c|}{ About 35 miles south of Indian Bathtub Spring } \\
\hline${ }^{1} 13 \mathrm{~S}-9 \mathrm{E}-35 \mathrm{CDCl}$ & 5,250 & 953 & $\begin{array}{l}853-873 \\
938-953\end{array}$ & $7-16-56$ & 840 & 623 & $7-16-56$ & Rhyolite \\
\hline \multicolumn{9}{|l|}{ Test holes } \\
\hline $\begin{array}{l}{ }^{2} 7 \mathrm{~S}-6 \mathrm{E}-29 \mathrm{BBAl} \\
{ }^{2} \mathrm{~S}-6 \mathrm{E}-34 \mathrm{BCAl} \\
{ }^{2} 8 \mathrm{~S}-6 \mathrm{E}-3 \mathrm{BDCl} \\
{ }^{2} 8 \mathrm{~S}-6 \mathrm{E}-4 \mathrm{DCD} 1\end{array}$ & $\begin{array}{l}2,832.5 \\
2,889.5 \\
2,754.6 \\
2,837.7\end{array}$ & $\begin{array}{l}760 \\
681 \\
480 \\
600\end{array}$ & $\begin{array}{l}415-760 \\
322-681 \\
194-480 \\
170-600\end{array}$ & $\begin{array}{l}5-14-90 \\
4-25-90 \\
3-31-90 \\
4-14-90\end{array}$ & $\begin{array}{r}233 \\
300 \\
90 \\
170\end{array}$ & $\begin{array}{l}157 \\
211 \\
76.1 \\
158\end{array}$ & $\begin{array}{l}5-23-90 \\
4-27-90 \\
4-1-90 \\
4-17-90\end{array}$ & $\begin{array}{l}\text { Tuffaceous siltstone } \\
\text { Basalt, silt, and sand } \\
\text { Basalt and tuffaceous silt and sand } \\
\text { Basalt }\end{array}$ \\
\hline
\end{tabular}

\footnotetext{
1 Data from drilling records on file in the Boise, Idaho, office of the U.S. Geological Survey.

${ }^{2}$ Data from Young and others ( 1990 ).
} 
(1957, p. 173) indicated that many of the springs are along faults that allow water to flow upward and reach land surface because of sufficiently high hydraulic head. They described Indian Bathtub Spring as at the contact between basalt and weathered tuff. Recent geologic mapping in the study area by M.D. Jenks and others (Idaho Geological Survey, written commun., 1992) indicated that basalts near Indian Bathtub are more faulted and fractured than previous investigators thought. M.D. Jenks and others also indicated that basalt in the vicinity of Indian Bathtub Spring consists of many flows with interbedded sediments. They noted no evidence of faulting in the basalts or sediments at Indian Bathtub Spring, which indicates that the spring is not fault related. Additional geologic data are needed to determine geologic controls on springs, especially Indian Bathtub Spring.

Most previous investigators indicated that nearly all springs in the study area originate from the volcanic-rock aquifer. Young and Whitehead (1975) and Rightmire and others (1976) suggested that, on the basis of the similarity of water temperature, electrical conductivity, concentrations of major ions, and values of stable hydrogen and oxygen isotopes, water from the springs has moved upward from the volcanic rocks. Water from the eight test holes at four sites near Indian Bathtub Spring (Young and others, 1990) has essentially the same physical and chemical characteristics as does water from the springs, further evidence that spring water is from the volcanic rocks.

\section{Hydraulic Characteristics}

Aquifer properties, including transmissivity, hydraulic conductivity, and storage coefficient, affect the rate at which water moves through an aquifer, the amount of water in storage, and the rate and areal extent of water-level declines caused by ground-water development. Aquifer properties in the study area vary considerably because of the heterogeneity of the rocks composing the aquifers. Aquifer properties were estimated from aquifer, slug, and specific-capacity tests.

\section{Transmissivity and Hydraulic Conductivity}

Transmissivity $(T)$ is the rate at which water is transmitted through a unit width of the aquifer under a unit hydraulic gradient (Lohman, 1972, p. 6); hydraulic conductivity is the capacity of a rock or unconsolidated material to transmit water in a unit of time through a unit area under a unit hydraulic gradient through a unit length of flow (Lohman, 1972, p. 6). Transmissivity of an aquifer is equal to hydraulic conductivity times aquifer thickness. Transmissivity and hydraulic conductivity were estimated from (1) four aquifer tests conducted by private consultants, (2) five slug tests conducted during this study, and (3) numerous specific-capacity tests conducted by drillers and entered into the U.S. Geological Survey's National Water Data Storage and Retrieval System (WATSTORE) data base prior to the beginning of this study. Methods used to analyze each of these tests are discussed in the following sections.

\section{Aquifer Tests}

Two wells completed in volcanic rocks more than 23 mi south of Indian Bathtub Spring were tested by Richard Young (U.S. Geological Survey, written commun., 1963) to determine transmissivity of the volcanic rocks. Previously, no aquifer tests had been conducted in the study area. Well $11 \mathrm{~S}-7 \mathrm{E}-25 \mathrm{ACAl}$ (fig. 1), pumped at $27 \mathrm{gal} / \mathrm{min}$ for $20 \mathrm{~min}$, caused a water-level decline of $24 \mathrm{ft}$; calculated transmissivity was about $25 \mathrm{ft}^{2} / \mathrm{d}$. Well 12S-8E-6ADAl (fig. 1), pumped at $25 \mathrm{gal} / \mathrm{min}$ for 24 hours, caused a water-level decline of $11 \mathrm{ft}$; calculated transmissivity was about $110 \mathrm{ft}^{2} / \mathrm{d}$. These low transmissivity values probably are representative of the massive, unfractured silicic volcanic rocks as compared to the highly fractured, more transmissive volcanic rocks in the Bruneau study area.

Large-capacity irrigation wells in the study area were tested by L. Mink (Morrison-Knudsen Company, Inc., written commun., 1984) to determine aquifer properties. In the first aquifer test, transmissivities of $60,000 \mathrm{ft}^{2} / \mathrm{d}$ and $57,000 \mathrm{ft}^{2} / \mathrm{d}$ were calculated on the basis of pressure drawdown and recovery, respectively, in observation well 7S-5E-8BCCl (fig. 2B), located about $4,000 \mathrm{ft}$ from pumped well 7S-5E-7ABBI (fig. 3). These 
values probably are high because observation well $7 \mathrm{~S}-5 \mathrm{E}-8 \mathrm{BCCl}$ is open to $670 \mathrm{ft}$ of volcanic rocks and $410 \mathrm{ft}$ of sedimentary rocks, whereas the pumped well 7S-5E-7ABB 1, with an open interval of $993 \mathrm{ft}$, is open entirely to volcanic rocks (fig. 3). In the second aquifer test, well 7S-6E-22CCDA 1 (fig. 2B) flowed for 20 hours at a rate of about $2,500 \mathrm{gal} / \mathrm{min}$; transmissivity, calculated from the pressure recovery phase of the test, was about $29,000 \mathrm{ft}^{2} / \mathrm{d}$ from an open interval of $472 \mathrm{ft}$. This value is probably a composite of the two rock types because one-third of the well is open to sedimentary rocks and two-thirds to volcanic rocks. L. Mink (Morrison-Knudsen Company, lnc., written commun., 1984) indicated that neither of the two observation wells, the closest being $1 \mathrm{mi}$ from the production well, had any water-level changes. The highly fractured nature of the volcanic rocks in the study area allows water to be readily transmitted to wells and accounts for the high transmissivity.

\section{Slug Tests}

The most commonly used method for analyzing water-level response to a slug or bailer test, where a known volume of water is instantaneously injected into or removed from a well completed in a confined aquifer, is that of Cooper and others (1967, p. 263-269). This method is for nonoscillatory responses. However, three of the five slug tests conducted during this study generated oscillatory responses. Those tests were analyzed using methods developed by van der Kamp (1976) and Kipp (1985). Van der Kamp's method is an approximate solution in the form of a decaying sinusoidal curve to the equations governing the well/aquifer system. Kipp's method uses a numerical inversion of the Laplace-transform solution that takes into account inertial effects and well-bore storage. Kipp's method is better suited to slug tests conducted during this study than is van der Kamp's method; therefore, it was used for analysis. Analysis indicated that the oscillatory behavior was caused by inertial effects.

Assumptions made for both methods were that (1) the aquifer is homogeneous and isotropic, (2) the aquifer has uniform thickness with impermeable upper and lower confining boundaries, (3) the change in volume of water removed or added is instantaneous, (4) the initial potentiometric surface is horizontal, (5) there are no delayed yield effects, and (6) the water is of constant density in the well bore and constant compressibility in the aquifer. Aquifers are seldom as ideal as outlined; however, these assumptions are most nearly met by confined aquifers where wells are at considerable distances from aquifer boundaries. A full explanation of the theoretical development, solution technique, numerical solution and resulting type curves, and examples of slug test analysis are included in reports by Cooper and others (1967, p. 263-269) for nonoscillatory behavior and by Kipp $(1985$, p. 1,397-1,408) for oscillatory behavior.

Test holes 8S-6E-3BDC2 and 8S-6E-3BDC3 (fig. 2B), open mainly to sedimentary rocks, were slug tested and analyzed using type curves developed by Cooper and others (1967). The water level against time data were read from pressure transducers; the dimensionless water-level displacement $\left(H / H_{0}\right)$ was plotted against the logarithm of time as shown in figure 5. For test hole $8 \mathrm{~S}-6 \mathrm{E}-3 \mathrm{BDC} 2$, a good match to the type curve with a dimensionless storage parameter $(\alpha)$ of $10^{-4}$ was obtained; the match point was $t=33 s$ at $T t / r_{\mathrm{c}}{ }^{2}=1$. Field data greater than 50 seconds were used because data collected early in the test probably were affected by the hydraulic properties and large volume of the surrounding gravel pack. The gravel pack consists of permeable pea gravel that extends 2 in. beyond the casing and more than $20 \mathrm{ft}$ above the potentiometric surface. Therefore, transmissivity estimates from data collected later in the test probably best represent the aquifer. A storage coefficient of 0.00001 was used for this analysis and was derived by multiplying aquifer thickness by a specific storage coefficient of $1 \times 10^{-6} \mathrm{ft}^{-1}$ (Lohman, 1972, p. 53). The test hole's open interval was used as the aquifer thickness. The calculated transmissivity of $160 \mathrm{ft}^{2} / \mathrm{d}$ is probably representative of the fine-grained rocks tested (fig. 4; Young and others, 1990, fig. 2, p. 8-9). A hydraulic conductivity of $16 \mathrm{ft} / \mathrm{d}$ was calculated by dividing the transmissivity by the well's perforated interval of $10 \mathrm{ft}$. Bouwer (1978, p. 38) indicated that a hydraulic conductivity of $16 \mathrm{ft} / \mathrm{d}$ is within the fine-sand category. Test hole $8 \mathrm{~S}-6 \mathrm{E}-3 \mathrm{BDC} 3$ responded more rapidly to slugging and the test was completed within about 50 seconds. A good match to the type curve with an $\alpha$ of $10^{-4}$ was obtained (fig. 5); the 

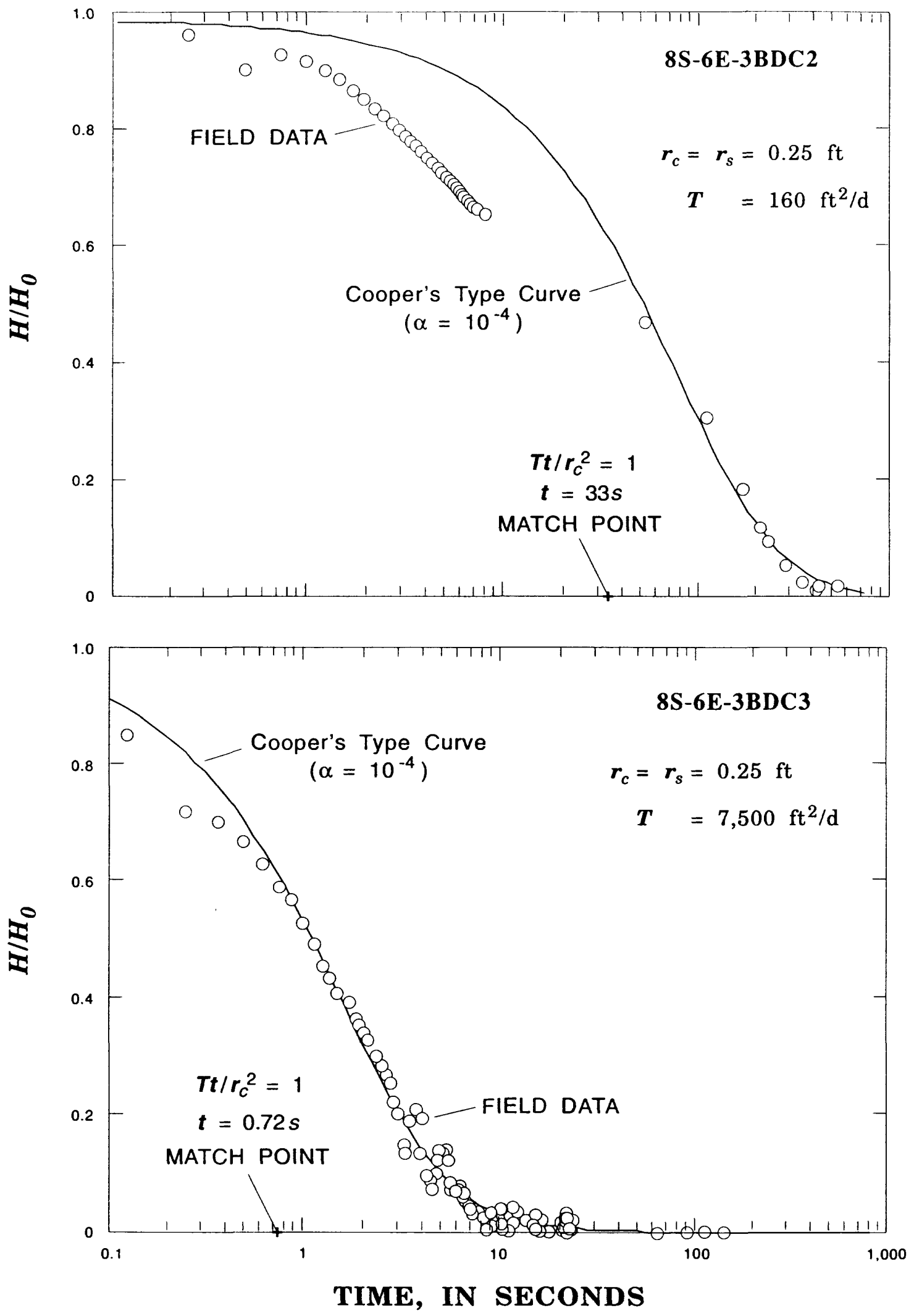

Figure 5. Application of method of Cooper and others (1967) to analysis of slug tests in test holes $8 \mathrm{~S}-6 \mathrm{E}-3 \mathrm{BDC} 2$ and $8 \mathrm{~S}-6 \mathrm{E}-3 \mathrm{BDC} 3$. 
match point was $t=0.72 \mathrm{~s}$ at $T t / r_{\mathrm{c}}{ }^{2}=1$. A storage coefficient of 0.00002 was used. Transmissivity was calculated to be about $7,500 \mathrm{ft}^{2} / \mathrm{d}$. This value is higher than that for test hole $8 \mathrm{~S}-6 \mathrm{E}-3 \mathrm{BDC} 2$ because the gravel pack is opposite $20 \mathrm{ft}$ of basalt and $20 \mathrm{ft}$ of sedimentary rocks (fig. 4; Young and others, 1990, fig. 2, p. 8-9). To determine the hydraulic conductivity of the basalt, it was assumed that the fine-grained rocks above and below the basalt were similar and had a hydraulic conductivity of $16 \mathrm{ft} / \mathrm{d}$, as determined from the previous slug test. Therefore, the resulting value of hydraulic conductivity for the basalt was about $360 \mathrm{ft} / \mathrm{d}$.

Test holes 7S-6E-29BBA1, 8S-6E-3BDC1, and $8 \mathrm{~S}-6 \mathrm{E}-4 \mathrm{DCD} 1$ (fig. 2B), open mainly to basalt, were slug tested and analyzed using type curves developed by Kipp (1985). The water level as a function of time data were read from pressure transducers; the dimensionless water-level displacement $\left(w^{\prime}\right)$ was plotted against the logarithm of time as shown in figure 6. Kipp's $w^{\prime}$ can be equated with the $H / H_{0}$ of Cooper and others (1967) by multiplying the numerator by -1 to account for the oscillatory behavior about $w^{\prime}=0\left(w^{\prime}=-H / H_{0}\right)$. A storage coefficient of 0.0003 was used for analysis of test holes 7S-6E-29BBA1 and 8S-6E-3BDC1 and 0.0004 was used for test hole 8S-6E-4DCD1. These values were derived by multiplying aquifer thickness by a specific storage coefficient of $1 \times 10^{-6} \mathrm{ft}^{-1}$ (Lohman, 1972, p. 53). The test hole's open interval was used as the aquifer thickness. Storage coefficients of 0.0003 and 0.0004 are reasonable for confined aquifers. Data for test hole 7S-6E-29BBA1 reasonably matched the type curve with a damping factor $(\zeta)$ of 0.20 (fig. 6 ); the match point was $t=3.75 s$ at $\hat{t}=1$. Calculated transmissivity was $9,000 \mathrm{ft}^{2} / \mathrm{d}$, which is low due to the large amounts of fine-grained rocks in the vicinity of this hole (fig. 4; Young and others, 1990, fig. 2, p. 5).

A type curve with a $\zeta$ of 0.04 was matched to the slug test data for test hole $8 \mathrm{~S}-6 \mathrm{E}-3 \mathrm{BDCl}$

(fig. 6); the match point was $t=2 s$ at $\hat{t}=1$. Calculated transmissivity was $100,000 \mathrm{ft}^{2} / \mathrm{d}$, the highest estimated from the five slug tests. This high value is believed to be representative of basalt in the area. The hole tested is open to $285 \mathrm{ft}$ of basalt and $6 \mathrm{ft}$ of fine sand from 219 to $225 \mathrm{ft}$ (Young and others, 1990, fig. 2, p. 9). If the hydraulic conductivity of $16 \mathrm{ft} / \mathrm{d}$ for sedimentary rocks in test hole
$8 \mathrm{~S}-6 \mathrm{E}-3 \mathrm{BDC} 2$ is used for the 6-ft fine-sand layer in $8 \mathrm{~S}-6 \mathrm{E}-3 \mathrm{BDC1}$ (fig. 2B), the resulting hydraulic conductivity of the basalt would be $355 \mathrm{ft} / \mathrm{d}$, which is about the same as the $360 \mathrm{ft} / \mathrm{d}$ obtained for well 8S-6E-3BDC3 (fig. 2B).

For test hole 8S-6E-4DCD1 (fig. 2B), a good match to the type curve with a $\zeta$ of 0.10 was obtained (fig. 6); the match point was $t=1.15 \mathrm{~s}$ at $\hat{t}=1$. Calculated transmissivity was $60,000 \mathrm{ft}^{2} / \mathrm{d}$, which is probably representative of basalt with lesser amounts of interbedded clay and fine-grained sand (fig. 4; Young and others, 1990, fig. 2, p. 10).

\section{Specific-Capacity Tests}

Specific-capacity data from the U.S. Geological Survey's WATSTORE (Baker, 1977) data base also were used to estimate transmissivities and hydraulic conductivities of sedimentary and volcanic rocks in the study area. Specific capacities are expressed as well yield, in gallons per minute per foot of drawdown [(gal/min)/ft]. Properly designed wells completed in aquifers with high transmissivities have higher specific capacities than do wells completed in aquifers with low transmissivities. Well drillers, the U.S. Geological Survey, and private consultants have made many specific-capacity tests on wells in the study area (table 2). Data indicate a wide range in specificcapacity values. Two wells completed exclusively in the cold-water aquifer had specific-capacity values of about $1(\mathrm{gal} / \mathrm{min}) / \mathrm{ft}$. Wells in the sedimentary-rock aquifer had values ranging from less than 1 to $100(\mathrm{gal} / \mathrm{min}) / \mathrm{ft}$; wells in the volcanic-rock aquifer had values ranging from 10 to about 200 (gal/min)/ft, except for well 7S-4E-23CBB1, which had a value of $700(\mathrm{gal} / \mathrm{min}) / \mathrm{ft}$. Wells 9S-5E-4DAD1, 11S-7E-25ACA1, 12S-8E6ADA1, and 13S-9E-35CDC1 are outside the study area (fig. 1) so were excluded from further analysis; however, these four wells are included in table 2 to show the hydraulic characteristics of the volcanic rocks upgradient from Indian Bathtub. 


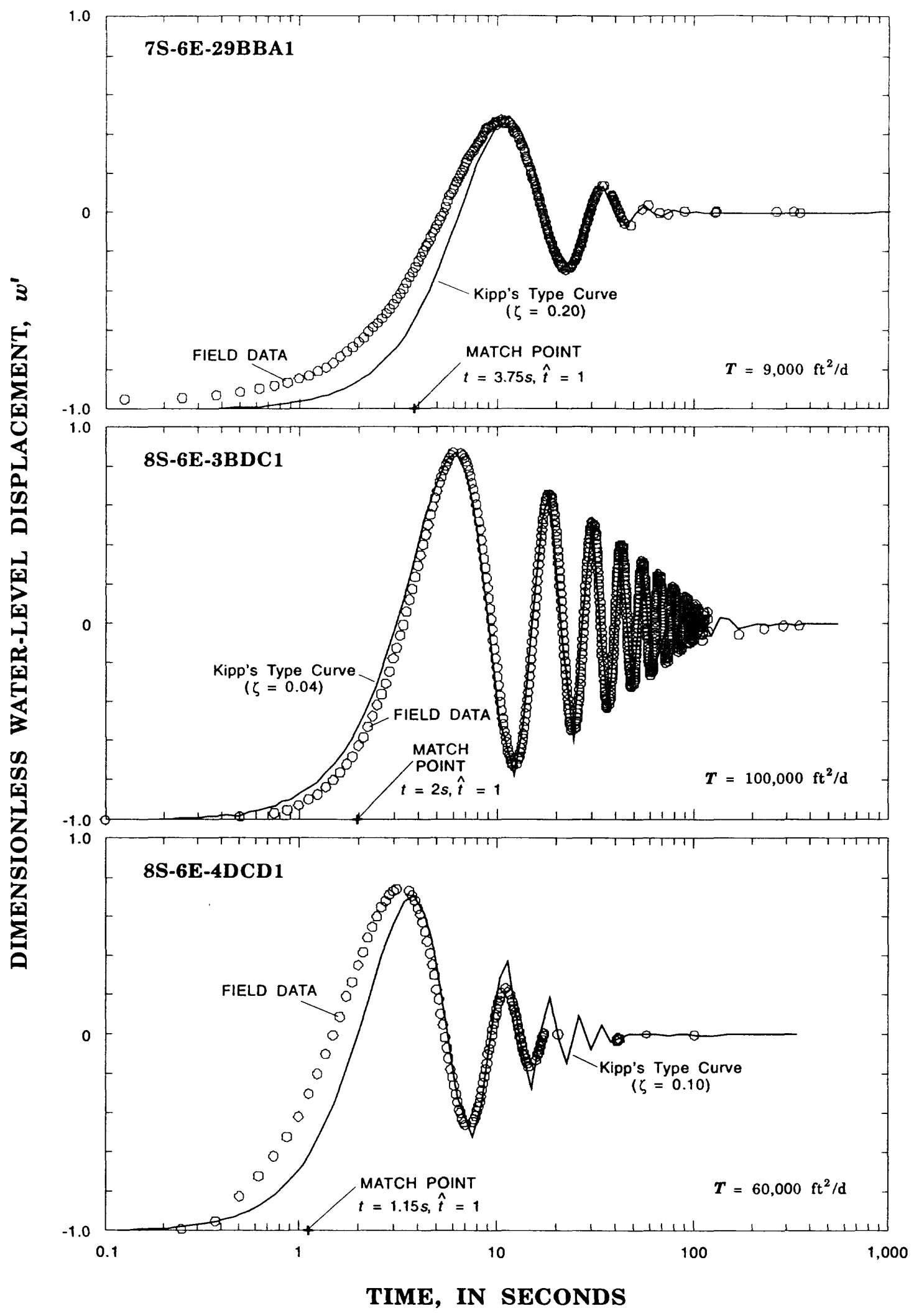

Figure 6. Application of method of Kipp (1985) to analysis of slug tests in test holes 7S-6E-29BBA1, 8S-6E-3BDC1, and 8S-6E-4DCD1. 
Table 2. Specific-capacity and construction data for wells in the Bruneau study area

[Aquifer tested: $\mathrm{Cw}$, cold-water; $\mathrm{Sr}$, sedimentary-rock; $\mathrm{Vr}$, volcanic-rock. Source of data: D, driller's log; US, U.S. Geological Survey; M, L.L. Mink, Morrison-Knudsen, Inc., written commun., 1984. Rock type: Vr, volcanic rocks; C, clay; S, sand; G, gravel. Abbreviations and symbols: gal/min, gallons per minute; $\mathrm{ft}$, feet; - , no data available; <, less than; negative value indicates water level above land surface]

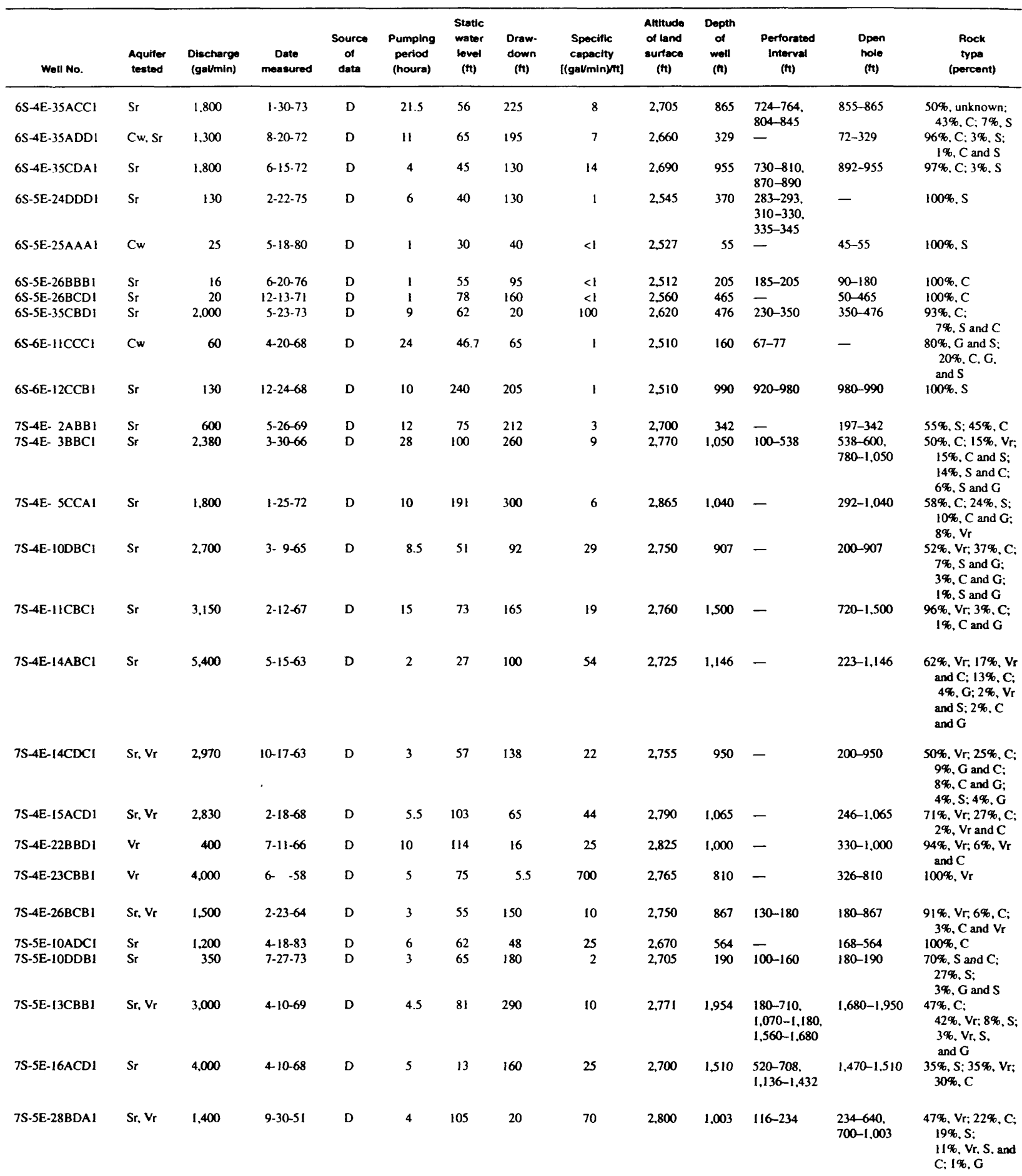


Table 2. Specific-capacity and construction data for wells in the Bruneau study area-Continued

\begin{tabular}{|c|c|c|c|c|c|c|c|c|c|c|c|c|c|}
\hline Well No. & $\begin{array}{l}\text { Aquiter } \\
\text { tested }\end{array}$ & $\begin{array}{l}\text { Discharge } \\
\text { (gal/min) }\end{array}$ & $\begin{array}{c}\text { Date } \\
\text { measured }\end{array}$ & $\begin{array}{c}\text { Source } \\
\text { of } \\
\text { data }\end{array}$ & $\begin{array}{l}\text { Pumping } \\
\text { period } \\
\text { (hours) }\end{array}$ & $\begin{array}{c}\text { Static } \\
\text { water } \\
\text { lovel } \\
\text { (t) }\end{array}$ & $\begin{array}{l}\text { Draw- } \\
\text { down } \\
\text { (tt) }\end{array}$ & $\begin{array}{c}\text { Specific } \\
\text { capacity } \\
\text { [(gaV/min)/tt] }\end{array}$ & $\begin{array}{l}\text { Aftitude } \\
\text { of land } \\
\text { surface } \\
\text { (ft) }\end{array}$ & $\begin{array}{l}\text { Depth } \\
\text { of } \\
\text { weli } \\
\text { (t) }\end{array}$ & $\begin{array}{l}\text { Perforated } \\
\text { intervai } \\
\text { (t) }\end{array}$ & $\begin{array}{l}\text { Open } \\
\text { hole } \\
\text { (tt) }\end{array}$ & $\begin{array}{c}\text { Rock } \\
\text { type } \\
\text { (percent) }\end{array}$ \\
\hline $7 S-6 E-16 A B B 2$ & $\mathrm{Sr}$ & 15 & $8-17.73$ & D & 1.5 & 6 & 23 & 1 & 2,553 & 190 & - & $158-190$ & $100 \%, S$ \\
\hline $7 \mathrm{~S}-6 \mathrm{E}-22 \mathrm{CCDA}$ & Sr. Vr & $\begin{array}{r}2,450 \\
385\end{array}$ & $\begin{array}{lr}4- & -84 \\
3-12-91\end{array}$ & $\begin{array}{l}\text { M } \\
\text { US }\end{array}$ & - & $\overline{55.40}$ & 7.41 & $\begin{array}{r}111 \\
52\end{array}$ & 2.605 & 630 & - & $158-630$ & $\begin{array}{l}78 \%, \mathrm{Vr} ; 22 \%, \mathrm{C} \\
\text { and } \mathrm{G}\end{array}$ \\
\hline $7 \mathrm{~S}-6 \mathrm{E}-34 \mathrm{BCA})$ & $v_{r}$ & 43.5 & $2-13-9 \mid$ & US & 4 & 217.24 & .5 & 87 & 2.8895 & 681 & - & $322-681$ & $\begin{array}{c}84 \%, \mathrm{Vr} ; 15 \%, \mathrm{C} \\
\text { and } \mathrm{S} ; 1 \% . \mathrm{S}\end{array}$ \\
\hline 7S-6E-34DADI & $\mathrm{Vr}$ & $\begin{array}{r}1.650 \\
111\end{array}$ & $\begin{array}{lr}4 & -84 \\
3-||-9 \mid\end{array}$ & $\begin{array}{l}\text { M } \\
\text { US }\end{array}$ & $\overline{1}$ & $\overline{-5.4}$ & $-\overline{3.5}$ & $\begin{array}{r}204 \\
32\end{array}$ & 2,725 & 300 & - & $46-300$ & $100 \%, \mathrm{Vr}$ \\
\hline 9S-5E- 4DAD I & $\mathrm{Vr}_{\mathrm{r}}$ & 240 & $12-31-59$ & D & 48.8 & 811 & 2 & 120 & 3.633 .5 & 2.500 & $1,880-2,480$ & - & $100 \% . \mathrm{Vr}_{\mathrm{r}}$ \\
\hline $11 \mathrm{~S}-7 \mathrm{E}-25 \mathrm{ACA} \mid$ & $\mathrm{Vr}$ & 27 & 7. $1-63$ & D & $<1$ & 846 & 24 & 1 & 4.345 & 1.400 & - & $20-1.400$ & $100 \% . V_{r}$ \\
\hline $12 S-8 E-6 A D A]$ & $v_{r}$ & $\begin{array}{l}25 \\
15\end{array}$ & $\begin{array}{r}9.1-63 \\
12-19-89\end{array}$ & $\begin{array}{l}\text { D } \\
\text { US }\end{array}$ & $\begin{array}{r}24 \\
1\end{array}$ & $\begin{array}{l}890 \\
893.82\end{array}$ & 111.76 & $\begin{array}{l}2 \\
8\end{array}$ & 4,450 & 1.400 & - & $40-1,400$ & $100 \%, \mathrm{Vr}$ \\
\hline $13 \mathrm{~S}-9 \mathrm{E}-35 \mathrm{CDCl}$ & $\mathrm{Vr}$ & 22 & $3-14-69$ & $\mathrm{D}$ & 24 & 637 & 24 & 1 & 5,250 & 953 & $\begin{array}{l}853-873 \\
938-953\end{array}$ & - & $100 \%, \mathrm{Vr}$ \\
\hline
\end{tabular}

Driscoll (1986, p. 1021) stated that for confined aquifers, specific capacity in units of gallons per minute per foot multiplied by 267 approximated transmissivity in units of feet squared per day. This relation between specific capacity and transmissivity was assumed to be representative of sedimentary and volcanic rocks in the study area. For example, L. Mink (Morrison-Knudsen Company, Inc., written commun., 1984) reported that the specific capacity for well 7S-6E-22CCDA1 (table 2) was $111(\mathrm{gal} / \mathrm{min}) / \mathrm{ft}$. If 111 is multiplied by 267 , estimated transmissivity is about $30,000 \mathrm{ft}^{2} / \mathrm{d}$, which is essentially the same as the calculated aquifer-test value of $29,000 \mathrm{ft}^{2} / \mathrm{d}$. This example supports Driscoll's assumption. The hydraulic conductivity of the sedimentary and volcanic rocks was estimated by dividing transmissivity estimated from specific-capacity data by saturated thickness of the aquifer (table 3). The estimated transmissivity and hydraulic conductivity values determined by this method ranged from less than $300 \mathrm{ft}^{2} / \mathrm{d}$ and $0.1 \mathrm{ft} / \mathrm{d}$ in the sedimentaryrock aquifer to $190,000 \mathrm{ft}^{2} / \mathrm{d}$ and $95 \mathrm{ft} / \mathrm{d}$ in the volcanic-rock aquifer. Values thus determined seem too low if the entire aquifer is not supplying water to the well. To correct for less than total aquifer thickness being contributory, a common practice is to assume that values of transmissivity calculated from specific-capacity tests apply only to the perforated interval of the well (Heath, 1983, p. 61). To apply this value to the entire aquifer thickness, calculated transmissivity is divided by the length of the perforated interval to determine hydraulic conductivity. Values thus determined then are multi- plied by the entire saturated thickness of the aquifer to obtain total aquifer transmissivity (table 3, fig. 4). Thickness of the sedimentary rocks is shown in figure 4 ; those values minus $100 \mathrm{ft}$, the thickness of the cold-water perched aquifer (see section, “Aquifers"), generally equals thickness of the sedimentary-rock aquifer. Thickness of the volcanic rocks is about 2,000 to $3,000 \mathrm{ft}$ (Young and Lewis, 1982, p. J4), and the assumed average is $2,500 \mathrm{ft}$. Where the sedimentary-rock aquifer overlies the volcanic-rock aquifer, in the northern part of the drainage area, volcanic-rock aquifer thickness was assumed to be about $2,500 \mathrm{ft}$, the total estimated thickness of the volcanic rocks. In the southern part of the study area, thickness of the volcanic-rock aquifer was assumed to be 2,500 $\mathrm{ft}$ (an average value) minus depth to the top of the confined aquifer, which is depth to first-encountered water. Using this method of estimation at well $12 \mathrm{~S}-8 \mathrm{E}-6 \mathrm{ADA} 1$, for example, the saturated thickness of the volcanic-rock aquifer is about $1,470 \mathrm{ft}[2,500 \mathrm{ft}-1,030 \mathrm{ft}$ (table 1 ) $=1,470 \mathrm{ft}$ (table 3)]. Transmissivity and hydraulic conductivity determined by this method ranged from $1,700 \mathrm{ft}^{2} / \mathrm{d}$ and $0.7 \mathrm{ft} / \mathrm{d}$ for the sedimentary-rock aquifer to $980,000 \mathrm{ft}^{2} / \mathrm{d}$ and $390 \mathrm{ft} / \mathrm{d}$ for the volcanic-rock aquifer. These values are too large if that part of the aquifer supplying water to the well is thicker than the length of the perforated interval and (or) open hole. Hydraulic properties determined by these methods and presented in table 3 probably represent the range of values for transmissivity and hydraulic conductivity in the study area. 
Table 3. Estimated transmissivity and hydraulic conductivity from specific-capacity tests for wells in the Bruneau study area

[Aquifer tested: $\mathrm{Cw}$, cold-water; $\mathrm{Sr}$, sedimentary-rock; $\mathrm{Vr}$, volcanic-rock. Abbreviations and symbols: (gal/min)/ft, gallons per minute per foot; $\mathrm{ft}^{2} / \mathrm{d}$, foot squared per day; $\mathrm{ft} / \mathrm{d}$, feet per day; $\mathrm{ft}$, foot; - , no data available; <, less than. Values in columns $\mathrm{B}, \mathrm{F}$, and $\mathrm{G}$ are rounded]

\begin{tabular}{|c|c|c|c|c|c|c|c|c|}
\hline Well No. & $\begin{array}{l}\text { Aquifer } \\
\text { tested }\end{array}$ & $\begin{array}{c}\text { Specific } \\
\text { capacity } \\
\text { [(gal/min)/ft] } \\
\text { (table 2) } \\
\text { (A) }\end{array}$ & $\begin{array}{c}\text { Trans- } \\
\text { missivity } \\
\left(\mathrm{ft}^{2} / \mathrm{d}\right) \\
(\mathrm{B}=\mathrm{A} \times 267)\end{array}$ & $\begin{array}{c}\text { Thickness } \\
\text { of aquifer } \\
\text { (ft) } \\
\text { (C) }\end{array}$ & $\begin{array}{c}\text { Hydraulic } \\
\text { conductivity } \\
\text { based on } \\
\text { total } \\
\text { saturated } \\
\text { thickness } \\
\text { (ft/d) } \\
\text { (D=B/C) }\end{array}$ & $\begin{array}{c}\text { Length of } \\
\text { perforated } \\
\text { interval } \\
\text { and (or) } \\
\text { open hole } \\
\text { (f) } \\
\text { (E) }\end{array}$ & $\begin{array}{c}\text { Hydraulic } \\
\text { conductivity } \\
\text { based on } \\
\text { length of } \\
\text { perforated } \\
\text { interval } \\
\text { (ft/d) } \\
\text { (F=B/E) }\end{array}$ & $\begin{array}{c}\text { Trans- } \\
\text { missivity } \\
\left(\mathrm{ft}^{2} / \mathrm{d}\right) \\
(\mathbf{G}=\mathbf{C} \times \mathbf{F})\end{array}$ \\
\hline $6 \mathrm{~S}-4 \mathrm{E}-35 \mathrm{ACCl}$ & $\mathrm{Sr}$ & 8 & 2,140 & 1,355 & 1.6 & 91 & 24 & 33,000 \\
\hline $6 \mathrm{~S}-4 \mathrm{E}-35 \mathrm{ADD} 1$ & $\mathrm{Cw}, \mathrm{Sr}$ & 7 & 1,900 & - & - & 257 & - & - \\
\hline $6 \mathrm{~S}-4 \mathrm{E}-35 \mathrm{CDA} 1$ & $\mathrm{Sr}$ & 14 & 3,700 & 1,140 & 3.3 & 163 & 23 & 26,000 \\
\hline 6S-5E-24DDDI & $\mathrm{Sr}$ & 1 & 300 & 2,195 & .1 & 40 & 8.0 & 18,000 \\
\hline $6 \mathrm{~S}-5 \mathrm{E}-25 \mathrm{AAAl}$ & $\mathrm{Cw}$ & $<1$ & $<300$ & 32 & $<9$ & 10 & $<30$ & $<1,000$ \\
\hline 6S-5E-26BBB। & $\mathrm{Sr}$ & $<1$ & $<300$ & 2,162 & $<.1$ & 110 & $<3$ & $<6,000$ \\
\hline $6 \mathrm{~S}-5 \mathrm{E}-26 \mathrm{BCD} \mathrm{I}$ & $\mathrm{Sr}$ & $<1$ & $<300$ & 2,260 & $<.1$ & 415 & $<.7$ & $<2,000$ \\
\hline $6 \mathrm{~S}-5 \mathrm{E}-35 \mathrm{CBD} 1$ & $\mathrm{Sr}$ & 100 & 27,000 & 2,320 & 12 & 246 & 110 & 260,000 \\
\hline $6 \mathrm{~S}-6 \mathrm{E}-11 \mathrm{CCC} 1$ & $\mathrm{Cw}$ & 1 & 300 & 30 & 10 & 10 & 30 & 900 \\
\hline $6 \mathrm{~S}-6 \mathrm{E}-12 \mathrm{CCB} 1$ & $\mathrm{Sr}$ & 1 & 300 & 1,860 & .2 & 70 & 4.3 & 8,000 \\
\hline $7 \mathrm{~S}-4 \mathrm{E}-2 \mathrm{ABB} 1$ & $\mathrm{Sr}$ & 3 & 800 & 1,100 & .7 & 145 & 5.5 & 6,000 \\
\hline $7 \mathrm{~S}-4 \mathrm{E}-3 \mathrm{BBCl}$ & $\mathrm{Sr}$ & 9 & 2,400 & 1,020 & 2.4 & 770 & 3.1 & 3,200 \\
\hline $7 S-4 E-5 C C A 1$ & $\mathrm{Sr}$ & 6 & 1,600 & 815 & 2.0 & 748 & 2.1 & 1,700 \\
\hline 7S-4E-10DBC1 & $\mathrm{Sr}$ & 29 & 7,800 & 650 & 12 & 707 & 11 & 7,200 \\
\hline $7 \mathrm{~S}-4 \mathrm{E}-11 \mathrm{CBC} 1$ & $\mathrm{Sr}$ & 19 & 5,100 & 891 & 5.7 & 780 & 6.5 & 5,800 \\
\hline $7 \mathrm{~S}-4 \mathrm{E}-14 \mathrm{ABCl}$ & $\mathrm{Sr}$ & 54 & 14,000 & 410 & 34 & 923 & 15 & 6,200 \\
\hline $7 \mathrm{~S}-4 \mathrm{E}-14 \mathrm{CDCl}$ & $\mathrm{Sr}, \mathrm{Vr}$ & 22 & 5,900 & - & - & 750 & - & - \\
\hline $7 \mathrm{~S}-4 \mathrm{E}-15 \mathrm{ACD} 1$ & $\mathrm{Sr}, \mathrm{Vr}$ & 44 & 12,000 & - & - & 819 & - & - \\
\hline $7 \mathrm{~S}-4 \mathrm{E}-22 \mathrm{BBD} 1$ & $\mathrm{Vr}$ & 25 & 6,700 & 2,500 & 2.7 & 670 & 10 & 25,000 \\
\hline $7 \mathrm{~S}-4 \mathrm{E}-23 \mathrm{CBB} 1$ & $\mathrm{Vr}$ & .700 & 190,000 & 2,500 & 76 & 484 & 390 & 980,000 \\
\hline $7 \mathrm{~S}-4 \mathrm{E}-26 \mathrm{BCB} 1$ & $\mathrm{Sr}, \mathrm{Vr}$ & 10 & 2,700 & - & - & 737 & - & - \\
\hline 7S-5E-10ADC1 & $\mathrm{Sr}$ & 25 & 6,700 & 1,678 & 4.0 & 396 & 17 & 29,000 \\
\hline 7S-5E-10DDB1 & $\mathrm{Sr}$ & 2 & 500 & 1,540 & .3 & 70 & 7.1 & 11,000 \\
\hline $7 \mathrm{~S}-5 \mathrm{E}-13 \mathrm{CBB} 1$ & $\mathrm{Sr}, \mathrm{Vr}$ & 10 & 2,700 & - & - & 1,030 & - & - \\
\hline 7S-5E-16ACD1 & $\mathrm{Sr}$ & 25 & 6,700 & 800 & 8.4 & 524 & 13 & 10,000 \\
\hline $7 \mathrm{~S}-5 \mathrm{E}-28 \mathrm{BDA} 1$ & $\mathrm{Sr}, \mathrm{Vr}$ & 70 & 19,000 & - & - & 827 & - & - \\
\hline 7S-6E-16ABB2 & $\mathrm{Sr}$ & 1 & 300 & 1,153 & .3 & 32 & 9.4 & 11,000 \\
\hline \multirow[t]{2}{*}{$7 \mathrm{~S}-6 \mathrm{E}-22 \mathrm{CCDA} 1$} & $\mathrm{Sr}, \mathrm{Vr}$ & 111 & 30,000 & - & - & 472 & - & - \\
\hline & & 52 & 14,000 & - & - & 472 & - & - \\
\hline 7S-6E-34BCA1 & $\mathrm{Vr}_{\mathrm{r}}$ & 87 & 23,000 & 2,178 & 11 & 359 & 64 & 140,000 \\
\hline \multirow[t]{2}{*}{ 7S-6E-34DAD1 } & $\mathrm{Vr}_{\mathrm{r}}$ & 204 & 54,000 & 2,454 & 22 & 254 & 210 & 520,000 \\
\hline & & 32 & 8,500 & 2,454 & 3.5 & 254 & 34 & 83,000 \\
\hline 9S-5E- 4DAD1 & $\mathrm{Vr}$ & 120 & 32,000 & 1,500 & 21 & 600 & 53 & 80,000 \\
\hline 11S-7E-25ACA1 & $\mathrm{Vr}_{\mathrm{r}}$ & 1 & 300 & 1,496 & .2 & 396 & .8 & 1,200 \\
\hline \multirow[t]{2}{*}{ 12S-8E-6ADA1 } & $\mathrm{Vr}$ & 2 & 500 & 1,470 & .3 & 370 & 1.4 & 2,100 \\
\hline & & 8 & 2,100 & 1,470 & 1.4 & 370 & 5.7 & 8,400 \\
\hline $13 \mathrm{~S}-9 \mathrm{E}-35 \mathrm{CDC} 1$ & $\mathrm{Vr}$ & 1 & 300 & 1,660 & .2 & 35 & 8.6 & 14,000 \\
\hline
\end{tabular}




\section{Storage Coefficient}

The storage coefficient of an aquifer is the volume of water released from or taken into storage per unit of surface area per unit change in head (Lohman, 1972, p. 8). For confined aquifers, the water released from storage when the hydraulic head declines comes from expansion of water and from compaction of the aquifer (Heath, 1983, p. 28). The sedimentary-rock aquifer, composed mainly of fine- to coarse-grained rocks with some volcanic rocks, is considered to be confined because it is overlain by fine-grained rocks. The volcanic-rock aquifer also is confined because it is overlain by sedimentary rocks, and where sedimentary rocks are absent, water in the volcanic rocks is confined by the dense volcanic rocks and fine-grained interbeds as discussed in the section, "Aquifers." Storage coefficient was determined at only one site where observation wells were available (L. Mink, Morrison-Knudsen Company, Inc., written commun., 1984). Mink calculated storage coefficients of 0.0002 and 0.0003 for the drawdown and recovery phases of the aquifer test at $7 \mathrm{~S}-5 \mathrm{E}-8 \mathrm{BCC}$. These values are lower than expected for the geothermal aquifer if aquifer thickness is assumed to be the same or greater than the well's open interval of $1,080 \mathrm{ft}$.

The minimum storage coefficient of confined aquifers also can be estimated by multiplying aquifer thickness by a specific storage coefficient of $1 \times 10^{-6} \mathrm{ft}^{-1}$ (Lohman, 1972, p. 53). The sedimentary rocks are as much as $2,000 \mathrm{ft}$ thick. Thickness of the sedimentary-rock aquifer at locations listed in table 3 ranges from about 400 to about $2,300 \mathrm{ft}$; therefore, storage coefficient is estimated to range from about 0.0004 to 0.002 . Thickness of the volcanic-rock aquifer at locations listed in table 3 ranges from about 1,500 to $2,500 \mathrm{ft}$; therefore, storage coefficient for the volcanic rocks is estimated to range from about 0.0015 to 0.0025 .

\section{THE GEOTHERMAL AQUIFER SYSTEM}

Before the effects of ground-water development on hydraulic heads and spring discharges could be determined, an understanding of the hydrology of the geothermal system in the study area was necessary. This involved (1) determining natural recharge to and discharge from the geothermal system, (2) determining discharge due to ground-water development, (3) defining potentiometric surfaces in the sedimentary- and volcanicrock aquifers, (4) identifying directions of groundwater movement, horizontally and vertically, and (5) developing a conceptual model of the geothermal system. A conceptual model can improve understanding of the geothermal system and the effects of ground-water development (groundwater discharge by wells) on water resources.

\section{Natural Recharge and Discharge}

Prior to extensive ground-water development in the Bruneau study area (fig. 1), long-term natural recharge to the geothermal system was balanced by natural discharge, a steady-state condition. During steady state, there is no change in ground-water storage.

Natural recharge to the geothermal system in the Bruneau study area originates almost entirely from precipitation on mountains to the south. Littleton and Crosthwaite (1957, p. 172) indicated that the highly fractured and faulted volcanic rocks along the Owyhee Mountain front (similarly, along the Jarbidge Mountain front) are highly permeable and permit water to infiltrate and move easily. For example, based on sparse data, they indicated that the entire "normal flow" of Little and Big Jacks Creeks and other creeks infiltrates to the groundwater system. At a small experimental watershed in the Owyhee Mountains about $30 \mathrm{mi}$ southwest of the study area, Stephenson and Zuzel (1981) studied rainfall-infiltration relations and indicated that recharge to the ground-water system probably is derived entirely from precipitation on the mountains. They determined that rainfall in excess of 0.8 to 1.2 in. over a 24 -hour period contributes significant quantities of water to the ground-water system. Because runoff infiltrates near the mountain front where streams first cross faulted and fractured volcanic rocks, the natural recharge is termed "mountain front recharge."

As rain falls on the volcanic rocks or overlying shallow soils, it can (1) be held as soil moisture, (2) infiltrate past the root zone to recharge the aquifer, (3) run off to stream channels and infiltrate 
to ground water through fractured, faulted, or otherwise permeable streambeds, or (4) be taken up by vegetation and transpired back to the atmosphere. Precipitation at Bruneau averages about $9 \mathrm{in} / \mathrm{yr}$; most is lost to evaporation, which, in the study area, averages about $45 \mathrm{in} / \mathrm{yr}$ from free water surfaces or from shallow lakes (Farnsworth and others, 1982). Precipitation that infiltrates the soil eventually is consumed by native and cultivated plants that can transpire several feet of water per year if water is available to the root zone. In the valleys, the cold-water aquifer receives a small amount of recharge from precipitation in addition to recharge from canals, applied irrigation water, and streams. Gemperle (1988, p. 41-43) indicated that the Bruneau River probably contributes water to the coldwater aquifer where it first crosses sedimentary rocks in the valley. Little, if any, precipitation on the Bruneau study area infiltrates to the geothermal system.

Recharge to the geothermal system in the Bruneau study area was estimated by two methods, basin yield and hydraulic gradient (Darcy's equation). Using the basin yield method, Kjelstrom (1986) estimated average annual net water yield from the Bruneau River drainage basin upstream from streamflow-gaging stations for the period 1934-80. Net water yield is the total amount of water available from precipitation in a drainage area. Kjelstrom (1986) estimated net water yield by using regression analysis. Drainage area, mean annual precipitation, and percentage of forest cover were independent variables in the regression equation. Kjelstrom (1986) estimated underflow from the drainage basin upstream from gaging stations as net water yield minus irrigation water use and streamflow. The underflow estimate of Kjelstrom is recharge to the Bruneau study area.

Net water yield and other water budget terms were calculated for two contributing areas using streamflow data at gaging stations Bruneau River near Hot Spring (13168500) and Big Jacks Creek near Bruneau (13169500, fig. 1). These stations account for more than 90 percent of the drainage area contributing underflow to the Bruneau study area. Kjelstrom (1986) estimated that during 1934-80, net water yield from the Bruneau River and Big Jacks Creek drainage areas averaged 367,000 and 10,000 acre-ft/yr, respectively. Mean annual discharge at gaging stations Bruneau River near Hot Spring (water years 1910-14, 1944-80) and Big Jacks Creek near Bruneau (water years 1940-49, 1966-80) was 286,000 and 3,000 acre-ft/yr, respectively. Kjelstrom then adjusted the values of mean annual discharge to the period 1934-80. The revised estimate of discharge at Bruneau River near Hot Spring was 297,000 acre-ft/yr; the estimate at Big Jacks Creek did not change. An estimated 20,000 acre-ft of water per year was used for irrigation upstream from the Bruneau River near Hot Spring gaging station; water used for irrigation upstream from the Big Jacks Creek gaging station was negligible. Thus, natural recharge (underflow) was calculated to be 50,000 acre-ft/yr at Bruneau River near Hot Spring and 7,000 acre-ft/yr at Big Jacks Creek, and total natural recharge to the study area was calculated to be about 57,000 acre-ft/yr. This is a minimum value because underflow from 10 percent of the contributing area, drained by Little Jacks and Logan Creeks, has not been estimated.

Another method for estimating recharge to the Bruneau study area is to apply Darcy's equation (Bouwer, 1978, p. 48, eq. 3.13). This method uses estimates of hydraulic gradients, aquifer extent, and aquifer properties to estimate underflow (recharge to the Bruneau study area). Underflow was estimated at the southern boundary of the Bruneau study area (fig. 1) because estimates of hydraulic gradient (Young and Lewis, 1982, pl. 2) and hydraulic conductivity (table 3 ) were available.

The 1979 potentiometric surface map for the regional geothermal system in southwestern Idaho (Young and Lewis, 1982, pl. 2) indicates that ground-water movement is northwestward toward the Snake River. Darcy's equation, $Q=T I W$, was used to calculate underflow, where $Q$ is groundwater discharge (length ${ }^{3} /$ time); $T$ is transmissivity (length ${ }^{2} /$ time); $I$ is hydraulic gradient (length/ length); and $W$ is the width of the aquifer normal to the direction of flow (length). Wells 7S-6E34BCA1, 7S-6E-34DAD1, and 9S-5E-4DAD1 (figs. 1 and $2 \mathrm{~B}$ ), representative of the volcanicrock aquifer, were used for this analysis. The wells are located between the 2,600- and 2,800-ft potentiometric surface contours delineated by Young 
and Lewis (1982, pl. 2). Underflow was first estimated using conservative estimates of hydraulic conductivity, aquifer thickness, and width of the flow system. Transmissivity in this case was estimated by averaging the hydraulic conductivities for the wells listed above (table 3, column D) and multiplying that value by 1,500 , the approximate thickness, in feet, of the volcanic-rock aquifer at well 9S-5E-4DADI (table 3, column C). An average hydraulic conductivity from the two tests at well 7S-6E-34DADl was used. The average hydraulic conductivity for the three wells completed in the volcanic-rock aquifer is about $15 \mathrm{ft} / \mathrm{d}$; therefore, transmissivity $(T)$ would be about $22,000 \mathrm{ft}^{2} / \mathrm{d}$. If the hydraulic gradient $(I)$ is about $24 \mathrm{ft} / \mathrm{mi}$ (Young and Lewis, 1982, pl. 2) and the width $(W)$ is $35 \mathrm{mi}$, ground-water discharge $(Q)$ is calculated to be about $18,000,000 \mathrm{ft}^{3} / \mathrm{d}$, or about $150,000 \mathrm{acre}-\mathrm{ft} / \mathrm{yr}$. This estimate of underflow is nearly triple that estimated by the basin yield method.

However, uncertainties in hydraulic conductivity, aquifer thickness, aquifer width, and hydraulic gradient make estimates by the Darcy method questionable. Hydraulic conductivity for the three wells used to estimate underflow ranged from 3.5 to $22 \mathrm{ft} / \mathrm{d}$ (table 3, column D), a factor of about 6 . Using these high and low values of hydraulic conductivity to estimate transmissivity, underflow at the southern boundary is calculated to be about 230,000 and 37,000 acre-ft/yr, respectively. If transmissivity is estimated by averaging the results from the slug tests for test holes $8 \mathrm{~S}-6 \mathrm{E}-3 \mathrm{BDCl}$ and $8 \mathrm{~S}-6 \mathrm{E}-4 \mathrm{DCD} 1$ (fig. 6), underflow is calculated to be about 560,000 acre- $\mathrm{ft} / \mathrm{yr}$. This is more than the 377,000 acre- $\mathrm{ft} / \mathrm{yr}$ that is available from precipitation in the Bruneau River drainage area as presented in the basin yield method. Aquifer tests are

Table 4. Spring discharges in the Bruneau study area prior to extensive ground-water development

[gal/min, gallons per minute; acre-ft/yr, acre-feet per year. Values are rounded]

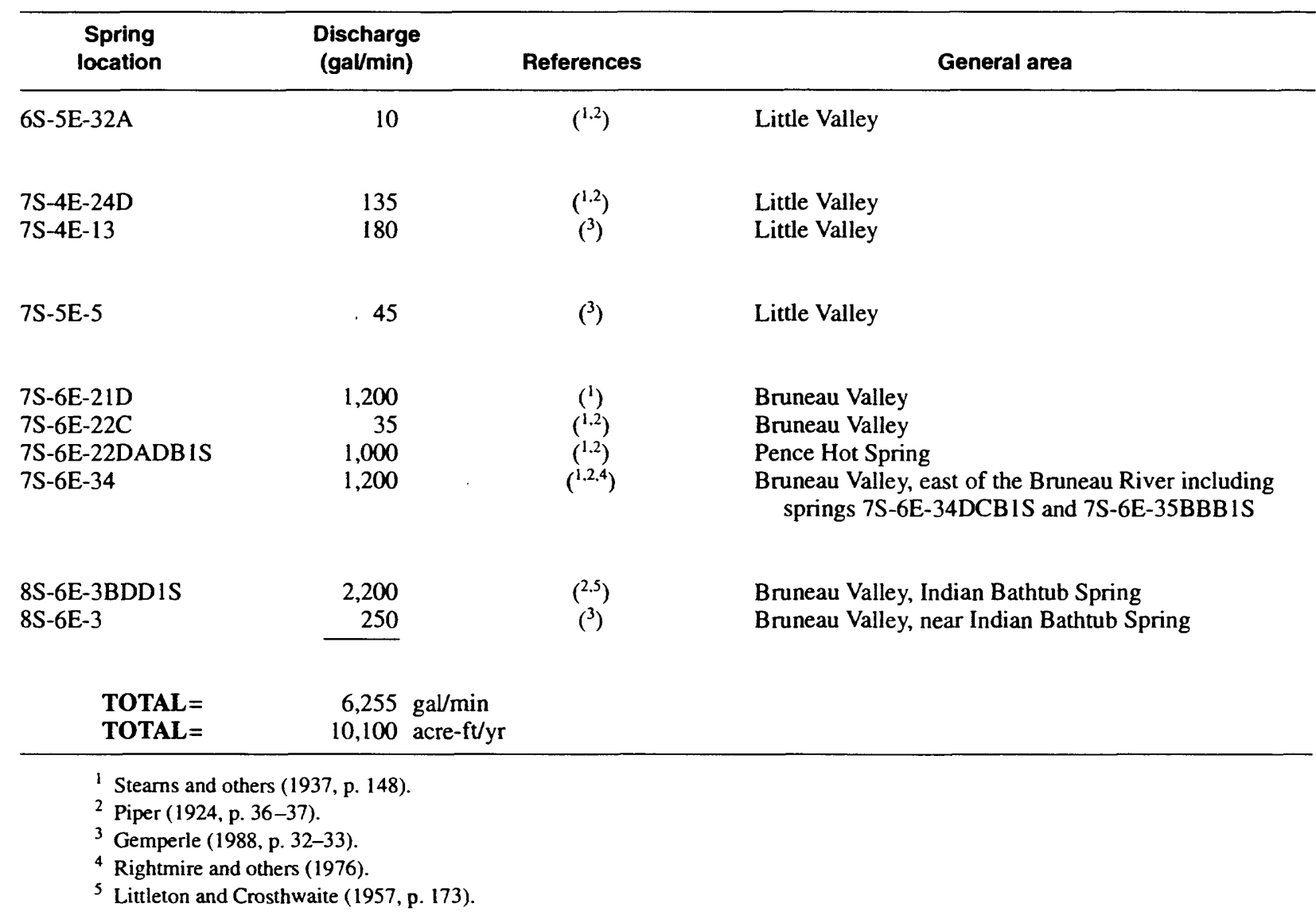


needed to more accurately determine hydraulic conductivities and transmissivities in this area. Also, no wells in the study area have penetrated the entire thickness of the volcanic-rock aquifer. Without a more accurate estimate of saturated thickness, hydraulic conductivity cannot be reliably converted into estimates of transmissivity. Aquifer width at the southern boundary was estimated to be about $35 \mathrm{mi}$. Additional drilling is needed to help define aquifer extent more precisely. Although more information is available on hydraulic gradients than on hydraulic properties for the study area, hydraulic gradient data are still sparse near the southern boundary. The level of uncertainty for any of these properties is unknown. If one of the properties is in error by a factor of two, underflow also will be in error by a factor of two because these properties are proportional to underflow $(Q)$. A smaller value of underflow would represent a more conservative estimate for water resource management purposes.

Natural discharge from the study area consists of spring flow and underflow to the Snake River and out of the Bruneau study area. Gemperle (1988, p. 31-34) estimated discharge from springs in the Bruneau-Grand View area prior to extensive ground-water development (1922). These estimates are probably representative of steady-state conditions because spring discharges did not change significantly from 1922 to 1954 (Littleton and Crosthwaite, 1957, p. 173) and were revised on the basis of more recent information and regrouping of springs in the Bruneau study area. Total estimated discharge from springs prior to extensive ground-water development was about 10,100 acre-ft/yr (table 4) - 9,500 acre-ft from Bruneau Valley and 600 acre-ft from Little Valley. Spring discharges given in table 4 were measured. Gemperle (1988, p. 32-33) also reported that two springs south of the study area near the Owyhee Mountains had a combined discharge of $1,260 \mathrm{gal} / \mathrm{min}$, or about 2,000 acre- $\mathrm{ft} / \mathrm{yr}$, if discharge is assumed to remain constant throughout the year. Young and Lewis (1982, table 1, p. J5) reported that several springs in the Jarbidge Mountains had a combined discharge of about $2,000 \mathrm{gal} / \mathrm{min}$, or $3,200 \mathrm{acre}-\mathrm{ft}$ in 1978 . Estimates of underflow to the Snake River and out of the Bruneau study area were not possible because of inadequate data.

\section{Ground-Water Development}

The Bruneau River provided water to early travelers and soon thereafter was used for irrigation. Bruneau, Little, and Sugar Valleys have supported irrigated agriculture for many years. The number of acres irrigated initially was dependent on the quantity of surface water available (Piper, 1924, p. 27). Shortly after the turn of the century, water from the Bruneau River was used to irrigate about 4,200 acres in the lower Bruneau River Valley and about 6,000 acres in the Grand View area (Piper, 1924, p. 33). Piper (1924, p. 35) also indicated that surface-water supply was inadequate during the summer when streamflows are lowest and recommended the use of ground water as a supplemental supply. In parts of Bruneau, Little, and Sugar Valleys, ground water is currently the sole source of supply.

In 1896, the first test holes were drilled in the lower Bruneau River Valley (near 6S-5E-9AD and 6S-5E-14DC, fig. 7) in an attempt to obtain artesian water from wells. That attempt was unsuccessful because drilling stopped at firstencountered water, which had a temperature of about $15^{\circ} \mathrm{C}$ (Piper, 1924, p. 40 , table 10 , wells 1 and 2). The test holes indicated the presence of a cold-water aquifer. That same year, five 2 -in.diameter wells were successfully completed in Little Valley near a geothermal spring in the southeastern corner of sec. 24, T. 7 S., R. 4 E. (fig. 7), and development of the regional geothermal aquifer system had begun. Locations of irrigation wells and year drilled in each of the three valleys are shown in figure 7. Water was used for irrigation, municipal, domestic, and stock supplies. From 1896 to 1912 , well drilling proceeded slowly and about 15 flowing wells were completed. The number of irrigation wells drilled increased to more than 100 in 1922 (fig. 8). By 1922, Piper (1924, p. 40-45) reported a total of 40,63 , and 4 wells in Bruneau, Little, and Sugar Valleys, respectively. Eighty of these wells flowed. Most of the flowing wells were less than $1,000 \mathrm{ft}$ deep and were completed in what Piper (1924, table 10, p. 40-45) called the valley aquifer (sedimentary-rock aquifer). The present quantity of water used for municipal, domestic, and stock supplies is small in comparison with the quantity used for irrigation. The Bruneau Water Company, which supplies the 


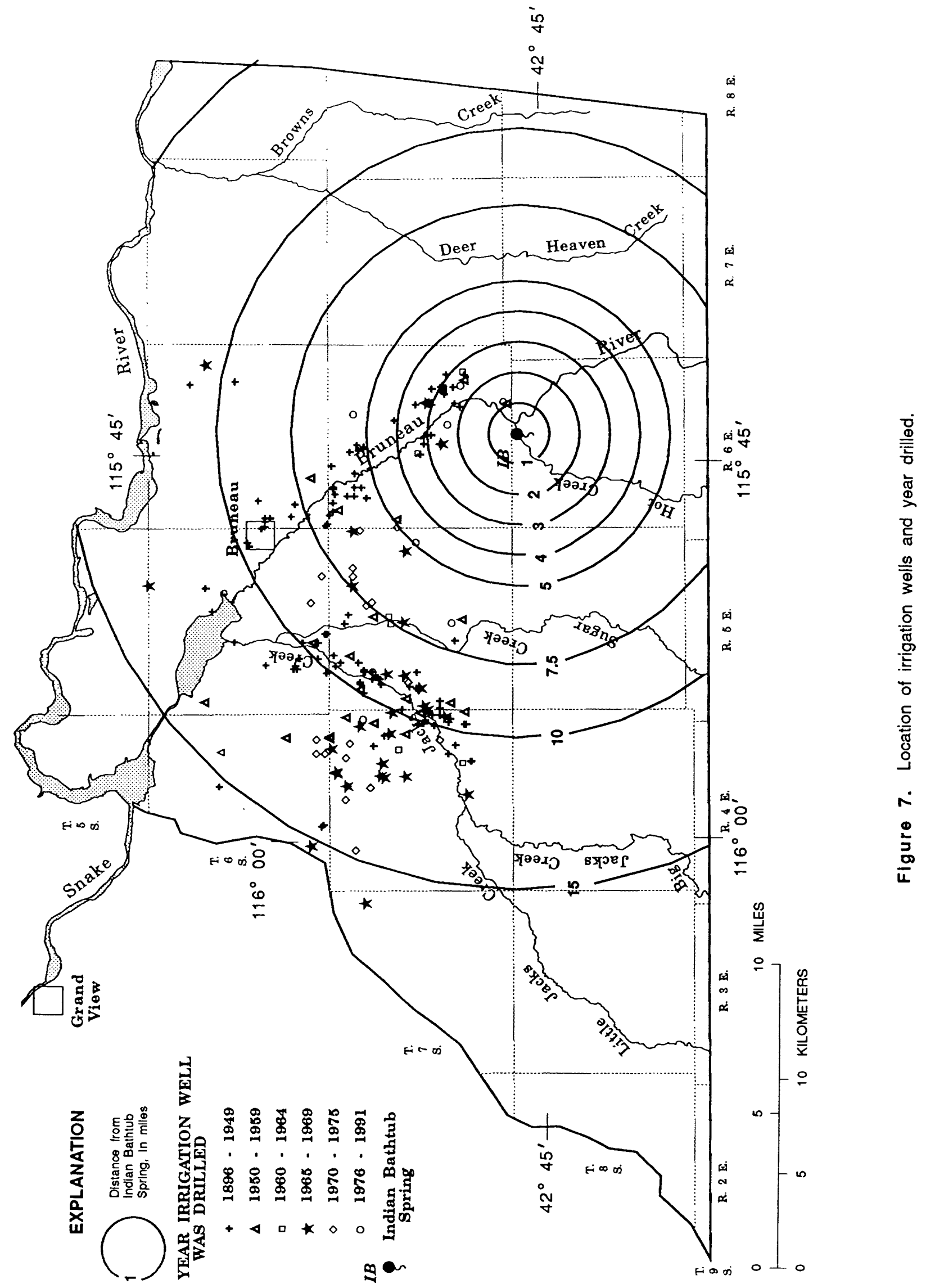




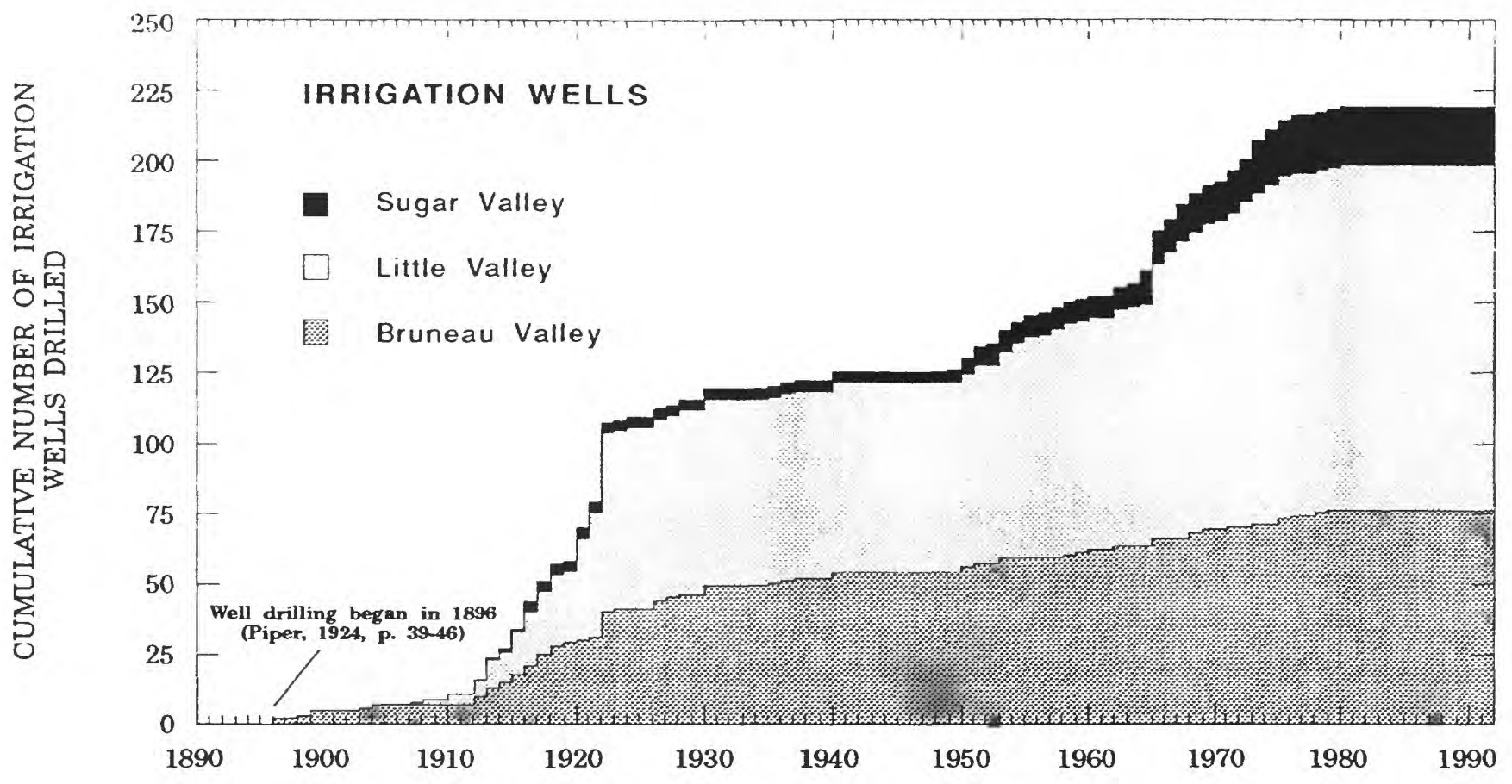

Figure 8. Cumulative number of irrigation wells drilled in the Bruneau area, 1890-1991.

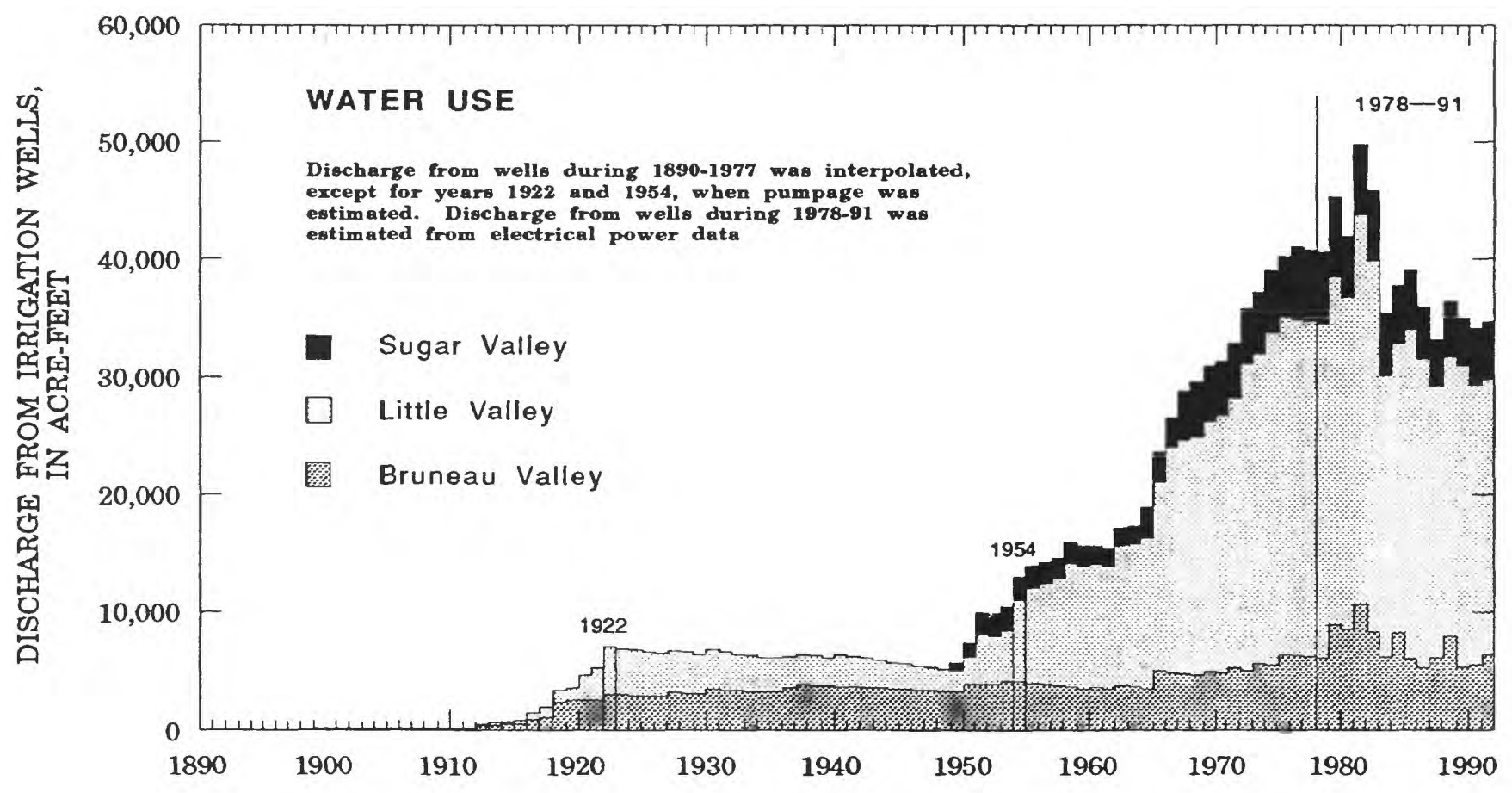

Figure 9. Distribution of annual discharge from irrigation wells in the Bruneau area, 1890-1991. 
city of Bruneau, is one of the largest nonirrigation users of ground water in the study area. During 1977,1978 , and 1989, they used about 13,13, and 25 acre-ft of water, respectively (Tom Moore, JUB Engineering, Inc., oral commun., 1991). Moore attributes the increase in pumpage from 1977 to 1989 to the conversion from individual septic-tank systems to a centralized sewage system in 1981 . The quantity of water for nonirrigation use in the study area probably has been less than 100 acre$\mathrm{ft} / \mathrm{yr}$ since 1991 and was not further considered in this study.

A substantial quantity of water has discharged from the regional geothermal system from flowing and pumped wells. In 1922, discharge from irrigation wells was estimated to be about 7,150 acre-ft (fig. 9) - about 3,150 acre-ft from Bruneau Valley and 4,000 acre-ft from Little Valley (Piper, 1924, p. 39-46). These estimates were made by measuring the discharge from all flowing wells at least once and assuming that the flow remained constant throughout the year because artesian pressures in the aquifer remained relatively constant (Littleton and Crosthwaite, 1957, p. 183). The distribution of annual discharge from wells in Bruneau, Little, and Sugar Valleys during 1890 to 1991 is shown in figure 9. Annual well discharges prior to 1922 were determined by using a well's 1922 discharge value given by Piper (1924, table 10, p. 40-45) as a constant from the time of well construction to 1922 . No attempt was made to account for annual variations in well discharge as noted by Piper (1924, table 10, p. 40-45) because accurate records of flow rates were not kept.

The number of wells drilled in the study area increased slowly from 1922 to 1954 (figs. 7 and 8). During that time, annual discharge nearly doubled (fig. 9). In 1954, Littleton and Crosthwaite (1957, p. 174) estimated that 81 wells discharged about 22,500 acre-ft of water, about three times as much as Piper's estimate for 1922. However, Piper's estimate was for Bruneau, Little, and Sugar Valleys, whereas Littleton and Crosthwaite's estimate included the Grand View area. For this report, Littleton and Crosthwaite's estimate was revised to exclude wells in the Grand View area, and the revised estimate of discharge from 51 wells in the Bruneau study area in 1954 was about 13,000 acre-ft. Twenty-eight of the wells were in
Bruneau Valley, 19 in Little Valley, and 4 in Sugar Valley, and the wells discharged about 4,200 , 6,800 , and 2,000 acre-ft, respectively (fig. 9). Littleton and Crosthwaite (1957) used the same procedure as Piper (1924) to calculate well discharges, except for 24 wells that were pumped or that flowed only during the irrigation season. Discharge from these wells was estimated by multiplying the estimated daily discharge by 100 , the average number of days wells flowed or were pumped in a year (Littleton and Crosthwaite, 1957, p. 174). Annual quantities of discharge for 1922-54 were determined by interpolating between 1922 and 1954 estimated values or by using the well's 1954 discharge value as a constant from the time of the well's construction to 1954 . Discharge from wells with a reported discharge in 1922 but none in 1954 was interpolated between the estimated 1922 value and the zero 1954 value because information about when the well was abandoned, destroyed, or not in use was unavailable. This probably accounts for the declining trend in annual discharge from 1922 to 1950 in Little Valley (fig. 9).

Land use in the study area changed significantly between 1954 and 1978. Lindholm and Goodell (1986) indicated that, in 1945, no appreciable amount of land in the study area was irrigated with ground water; by 1966 , about 13,000 acres were irrigated, and by 1980 , about 20,000 acres were irrigated. Intensive use of geothermal water for irrigation began in the mid1960's. Most of the increase in irrigated acreage since 1945 was in Little and Sugar Valleys. The number of wells drilled (73) also increased (figs. 7 and 8), although the dramatic increase in discharge from wells (fig. 9) during 1954-78 probably was caused by the addition of large-capacity pumps to increase well yields. Young and others (1979, table 2, p. 15) estimated that, in 1978, about 39,000 acre-ft of water was discharged from wells. Their estimate was based on total electrical consumption by pumps, depth to water, average water level, and well efficiency. The estimate by Young and others has been revised on the basis of more recent information and regrouping of wells. Total estimated discharge from wells in 1978 was about 40,600 acre- $\mathrm{ft}-6,200$ acre- $\mathrm{ft}$ from Bruneau Valley, 28,300 acre-ft from Little Valley, and 6,100 acre-ft from Sugar Valley (fig. 9). Annual 
quantities between 1954 and 1978 were interpo-

lated as previously described.

Only two irrigation wells were drilled in the study area during 1978-91 (fig. 8). One reason for curtailed drilling was that in 1982, the BruneauGrand View area was declared a Ground-Water Management Area by the Idaho Department of Water Resources. Most irrigation wells are in Little Valley (figs. 7 and 8), where annual discharge has been greatest since 1954 (fig. 9). Annual variations in discharge from irrigation wells from 1978 through 1991 are shown in figure 9. Total well discharge declined from the maximum of 49,900 acre- $\mathrm{ft}$ in 1981 to 34,700 acre-ft in 1991. From 1981 to 1991 , discharge from wells declined about 4,200 acre- $\mathrm{ft}$ in Bruneau Valley, 9,700 acre-ft in Little Valley, and 1,300 acre-ft in Sugar Valley. Declines are, in part, attributed to irrigated lands being idle as part of the "set-aside" program administered by the U.S. Department of Agriculture, Agricultural Stabilization and Conservation Service. In 1991, well discharges in Bruneau Valley totaled 6,500 acre- $\mathrm{ft}$; in Little Valley, 23,400 acre-ft; and in Sugar Valley, 4,800 acre-ft.

Irrigation well discharges prior to 1979 were estimated by previous investigators. Discharges from 1979 through 1991 were estimated during this study from annual electrical power data obtained from Idaho Power Company. Annual discharge was estimated by one of three methods. The first method was used only when an instantaneous discharge measurement was made and electrical power data were available. Annual well discharge was calculated as the product of the measured discharge and the time the pump was on. Discharge was assumed to remain constant. The second method was used when water-level measurements were made and electrical power data were available. Annual well discharge was calculated using the following equation, as described by Young and others $(1979$, p. 5, eq. 1$): Q=k W h /[K(H+P)]$, where $Q$ is pumpage, in acre-feet, $k W h$ is kilowatthours used; $K$ is kilowatthours required to lift 1 acre-ft of water $1 \mathrm{ft}$; $H$ is the depth to pumping water level, in feet; and $P$ is the pressure head at the well, in feet of water. At 100 -percent efficiency, $K=1.02$

$k W h / a c r e-\mathrm{ft}-\mathrm{ft}$; that is, it takes slightly more than 1 kilowatthour of electricity to lift 1 acre-ft of water $1 \mathrm{ft}$ (Goodell, 1988, p. E19). A $K$ value of 1.8, developed from efficiency data by Young and others $(1979$, p. 5), was used for this study. The third method was used when electrical power data were not available. Annual well discharge was calculated as the product of the measured discharge and the number of days in the year if the well flowed continuously, or 100 days if the well flowed only during the irrigation season (Littleton and Crosthwaite, 1957, p. 175). Annual discharge from several wells powered by internal-combustion engines was estimated as the product of measured discharge and the average number of pumping hours of all other wells in the study area (Young and others, 1979, p. 5).

From 1896 through 1991, nearly

$1,400,000$ acre-ft of ground water discharged from wells in the study area. Of that quantity, about 546,000 acre-ft discharged from 1978 through 1991; 50 percent was from wells 10 to $15 \mathrm{mi}$ from Indian Bathtub Spring (fig. 10 and table 5). During 1978-91, 85 percent of the discharge was from wells greater than $5 \mathrm{mi}$ from Indian Bathtub Spring (fig. 10). The closest wells, 1 to $2 \mathrm{mi}$ from this spring, discharged 2 percent $(11,000$ acre-ft) of the total during 1978-91, or about 790 acre-ft/yr. The percentage of annual well discharge for different distances from Indian Bathtub Spring did not change appreciably during 1978-91, although the distribution of pumpage in 1922 and 1954 was notably different (table 5). The percentage of pumpage in 1922 and 1954 was generally greater closer to Indian Bathtub Spring than at present, especially 2 to $3 \mathrm{mi}$ from the spring, as shown in table 5. About 31 percent of the discharge from wells in 1922 was within 5 mi of Indian Bathtub Spring, about 21 percent in 1954, and 15 percent during 1978-91.

Ground-water discharge from wells is documented reasonably well; however, separating the quantity according to aquifer (sedimentary-rock or volcanic-rock) is difficult. If wells are open to both aquifers, there is no way to distribute stress except by assuming that most of the water comes from the volcanic rocks. This assumption is probably reasonable because water is transmitted through the volcanic rocks (higher hydraulic conductivity) more easily than through the sedimentary rocks. For example, if hydraulic conductivity is $16 \mathrm{ft} / \mathrm{d}$ for the sedimentary rocks and $360 \mathrm{ft} / \mathrm{d}$ for the volcanic rocks (see section, "Slug Tests"), if both rock types 


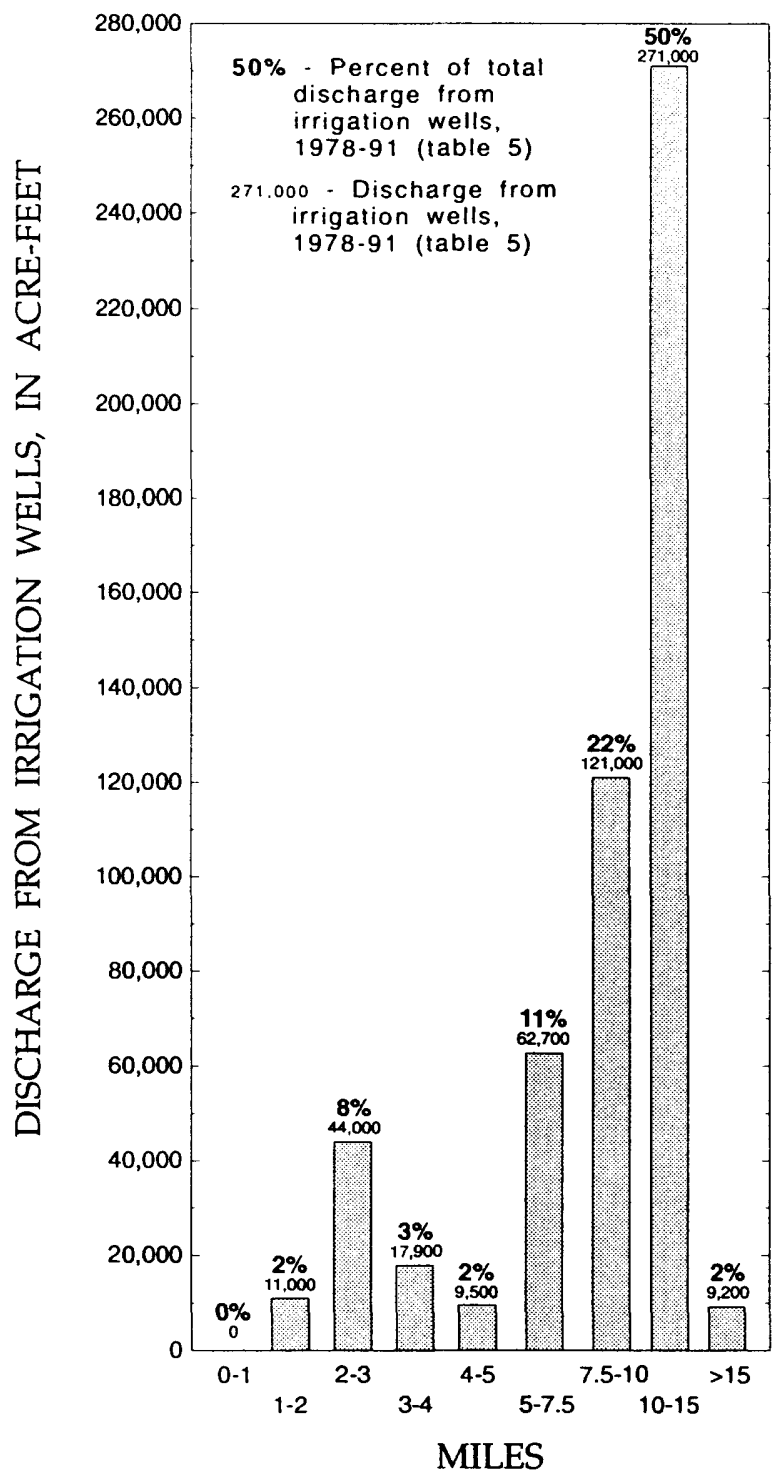

Figure 10. Discharge and percent of total from irrigation wells at various distances from Indian Bathtub Spring (8S-6E-3BDD1S), 1978-91. (Values are rounded) 
Table 5. Areal distribution of discharge from irrigation wells in the Bruneau study area, 1922, 1954, and 1978-91, at specified radial distances from Indian Bathtub Spring (8S-6E-3BDD1S)

[acre-ft, acre-feet; \%, percent; >, greater than. Values are rounded]

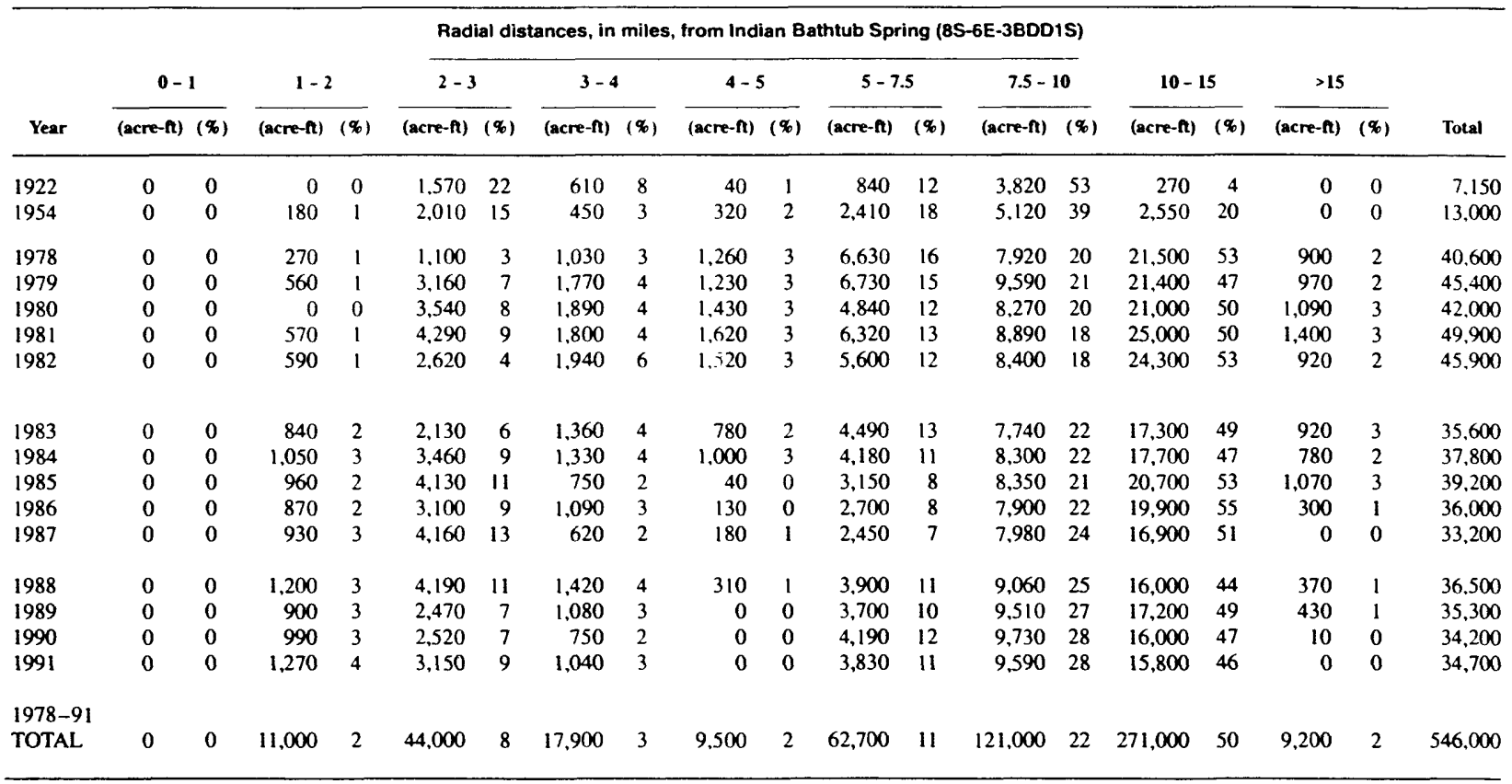

Table 6. Monthly consumptive use estimates based on evapotranspiration by alfalfa at Bruneau

[Adjusted evapotranspiration data from Allen and Brockway (1983, table 12, p. 134-135); mm/d, millimeters per day]

\begin{tabular}{lcc}
\hline Month & $\begin{array}{c}\text { Adjusted } \\
\text { evapo- } \\
\text { transpiration } \\
\text { (mm/d) }\end{array}$ & $\begin{array}{c}\text { Estimated } \\
\text { consumptive } \\
\text { use } \\
\text { (percent) }\end{array}$ \\
\hline January & 0 & \\
February & 0 & 0 \\
March & 2.52 & 0 \\
April & 4.97 & 5.34 \\
May & 6.56 & 10.53 \\
June & 8.28 & 13.90 \\
July & 8.58 & 17.54 \\
August & 7.13 & 18.17 \\
September & 5.41 & 15.10 \\
October & 3.76 & 11.46 \\
November & 0 & 7.96 \\
December & 0 & 0 \\
\hline
\end{tabular}

are of equal thickness, and if hydraulic gradients in both rock types are the same, 96 percent of the discharge might be from the volcanic rocks. Thus, wells open to both the sedimentary- and volcanicrock aquifers were treated as if they were completed solely in volcanic rocks. During 1978-91, about 70 percent of the well discharge in Little and Sugar Valleys was from wells open only to the volcanic-rock aquifer; about 90 percent of the well discharge in Bruneau Valley was from the volcanic-rock aquifer. Volcanic rocks are the main contributor of water to wells in the study area.

An attempt was made to estimate monthly discharge from irrigation wells, which varies throughout the year, especially during the irrigation season. Littleton and Crosthwaite (1957, p. 174) accounted for seasonal pumping in 1954 by using a 100-day well-pumping or flowing season; Young and others (1979) used the same procedure only for flowing wells that were shut off during nonirrigation periods. One widely used method of estimating discharge from irrigation wells incorporates crop consumptive water use. Allen and Brockway (1983) indicated that consumptive use is synonymous with evapotranspiration and determined the average monthly consumptive use for alfalfa. They adjusted the monthly consumptive use for station aridity at Bruneau and 97 other sites in Idaho. The consumptive use values determined for the Bruneau area by Allen and Brockway (table 6) are averages and representative of the study area where alfalfa, beans, corn, grain, and hay are grown. Hence, monthly well discharge can be estimated by multiplying each well's annual discharge by the monthly percentage of consumptive use (table 6). Only wells that had pumps were used for this analysis. 

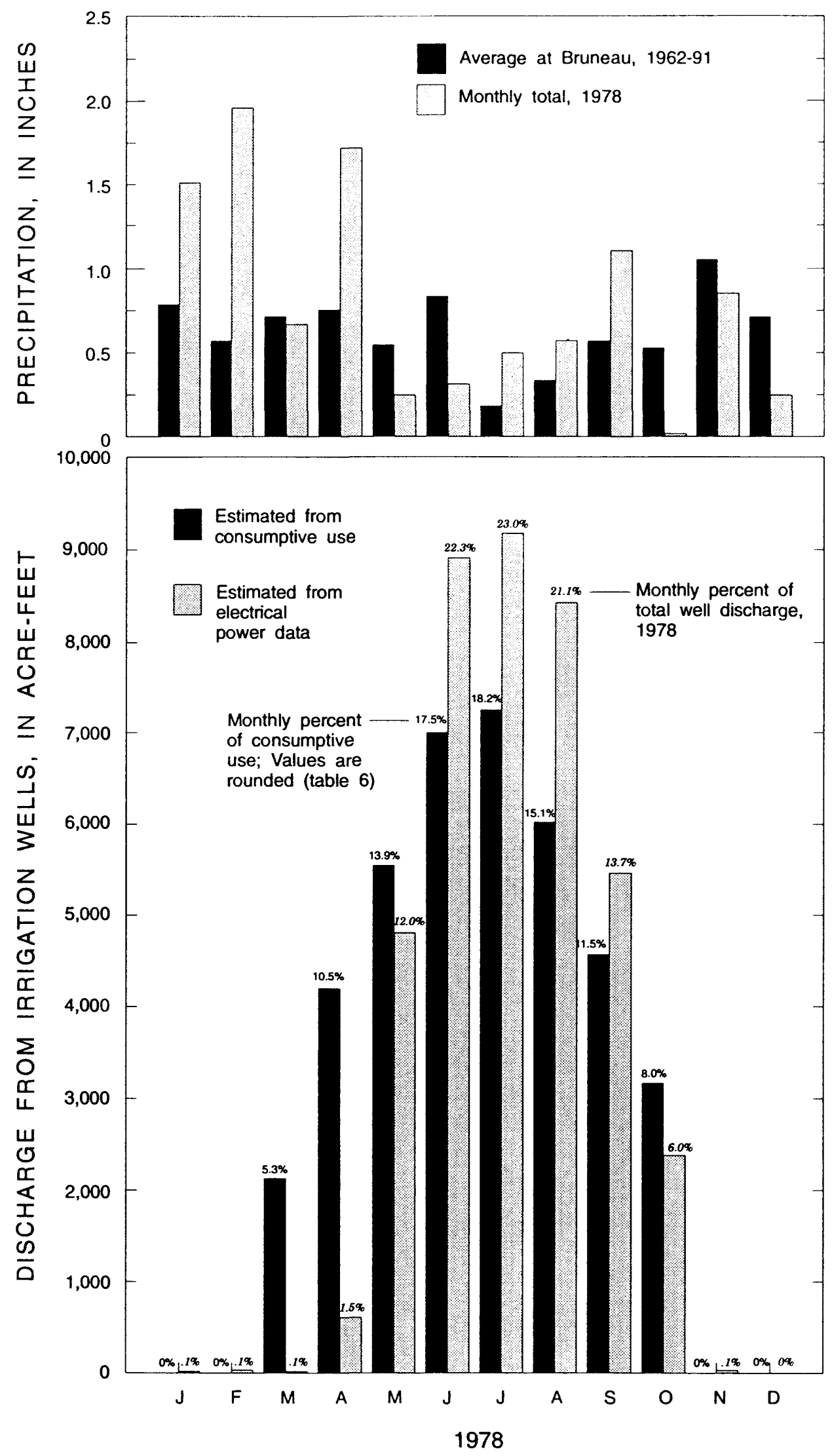

Figure 11. Average 1962-91 and monthly precipitation and monthly well discharge estimated from consumptive use and from electrical power data in the Bruneau area, 1978. 
Young and others (1979) calculated groundwater pumpage in 1978 by summing monthly discharges estimated from electrical power data. Only annual electrical power data were available for subsequent years. The relation between 1978 monthly discharge estimated from consumptive use and from electrical power data is shown in figure 11. Well discharge estimated by the consumptive use method generally was within 5 percent of that estimated from electrical power data. The largest discrepancies were in April and August. A possible explanation for these discrepancies is that precipitation was more than double the 1962-91 average in January, February, and April (fig. 11), and the need for irrigation water decreased. Under those conditions, well discharge estimated from electrical power data would be less than that estimated by the consumptive use method (fig. 11). Also, the lack of precipitation in June, compared to the average, created the need for more irrigation water throughout the summer than the amount estimated by the consumptive use method. Although there are some discrepancies between the two estimates, the consumptive use estimate generally followed the same trends as the electrical power data estimate, especially when precipitation was near normal.

The purpose of developing monthly estimates of ground-water pumpage by the consumptive use method was to help explain differences in hydraulic heads and spring flows in the last several years. Monthly electrical power data were not available. Since early 1989 , water levels in 12 wells and test holes and flows from 5 springs in the study area have been measured monthly (Young and Parliman, 1989; Young and others, 1990). Since April 1990, six test holes near Indian Bathtub Spring have been equipped with continuous water-level recorders (Young and others, 1990). To estimate the total monthly ground-water discharge by irrigation wells in 1990-91, the consumptive use method was applied to pumping wells and added to the monthly quantities discharged by flowing wells. The monthly distribution of well discharge for 1990-91 is shown in figure 12. The abundance of precipitation during the last 10 days of May 1990 (1.04 in.), compared with the average, lessened the need for irrigation water in May and June. As a result, actual well discharges were probably less than those estimated by the consumptive use method. The decrease in well discharge corresponded to an increase in hydraulic heads, as shown by the water levels in well 8S-6E-3BDCl (fig. 12). Conversely, the lack of precipitation during June through October 1990, March 1991, and July and August 1991, compared with the average, created the need for more irrigation water, and actual well discharge during those months was probably greater than that estimated by the consumptive use method. The lack of precipitation in July and August 1991 corresponded to greater water-level declines, as shown by the hydrograph for well 8S-6E-3BDC1, a well in the volcanic-rock aquifer open from 173.5 to $480 \mathrm{ft}$ below land surface (fig. 12). Consumptive use estimates for September and October 1991 were probably representative of actual well discharges because of nearaverage precipitation that corresponded to rising water levels (fig. 12).

\section{Potentiometric Surfaces and Water Movement}

Generally, ground water flows northward from areas of recharge along the mountains, through the volcanic-rock aquifer, and into the sedimentary-rock aquifer (Young and Lewis, 1982, p. J17). The potentiometric surface south of the study area was defined by Young and Lewis (1982, pl. 2) on the basis of water-level measurements made in spring 1979. That surface is considered representative of predevelopment conditions, probably unaffected by pumping. The potentiometric surface slopes steeply from an altitude of about $4,600 \mathrm{ft}$ near well 14S-9E-2BAAl (more than $40 \mathrm{mi}$ south of Indian Bathtub Spring) to slightly less than 2,800 ft near Indian Bathtub Spring, an average gradient of about $40 \mathrm{ft} / \mathrm{mi}$ (Young and Lewis, 1982, pl. 2). The spring 1979 potentiometric contours in the Bruneau study area are not representative of predevelopment conditions; however, they indicate that water movement is generally northward, toward the Snake River. Even water levels measured in the early 1920's showed declines due to the discharge of wells in the study area; therefore, they too are not representative of predevelopment conditions (Piper, 1924, p. 48). 

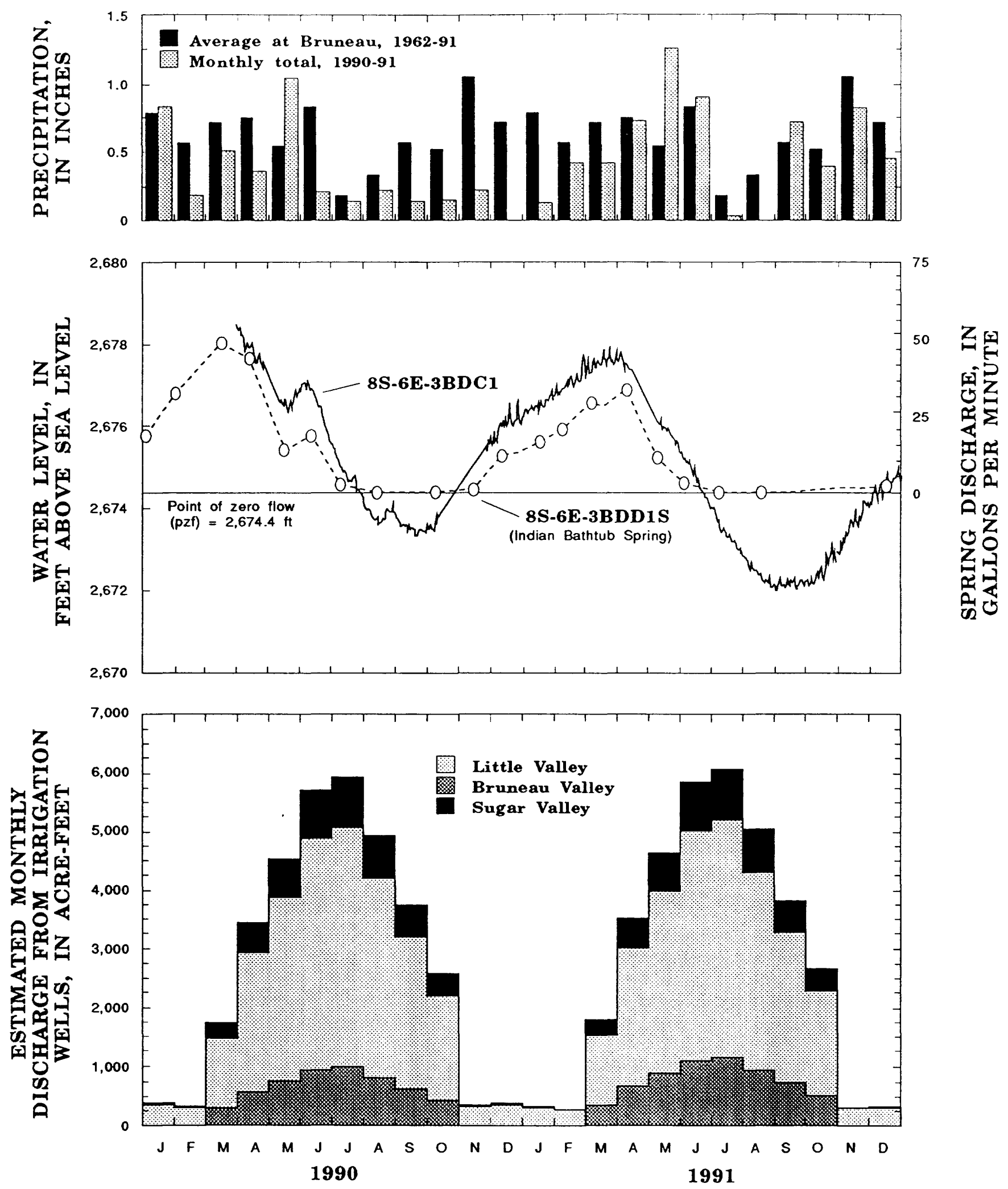

FIgure 12. Relations among precipitation, water level in test hole $8 S-6 E-3 B D C 1$, discharge from Indian Bathtub Spring (8S-6E-3BDD1S), and estimated monthly discharge from irrigation wells, 1990-91. 


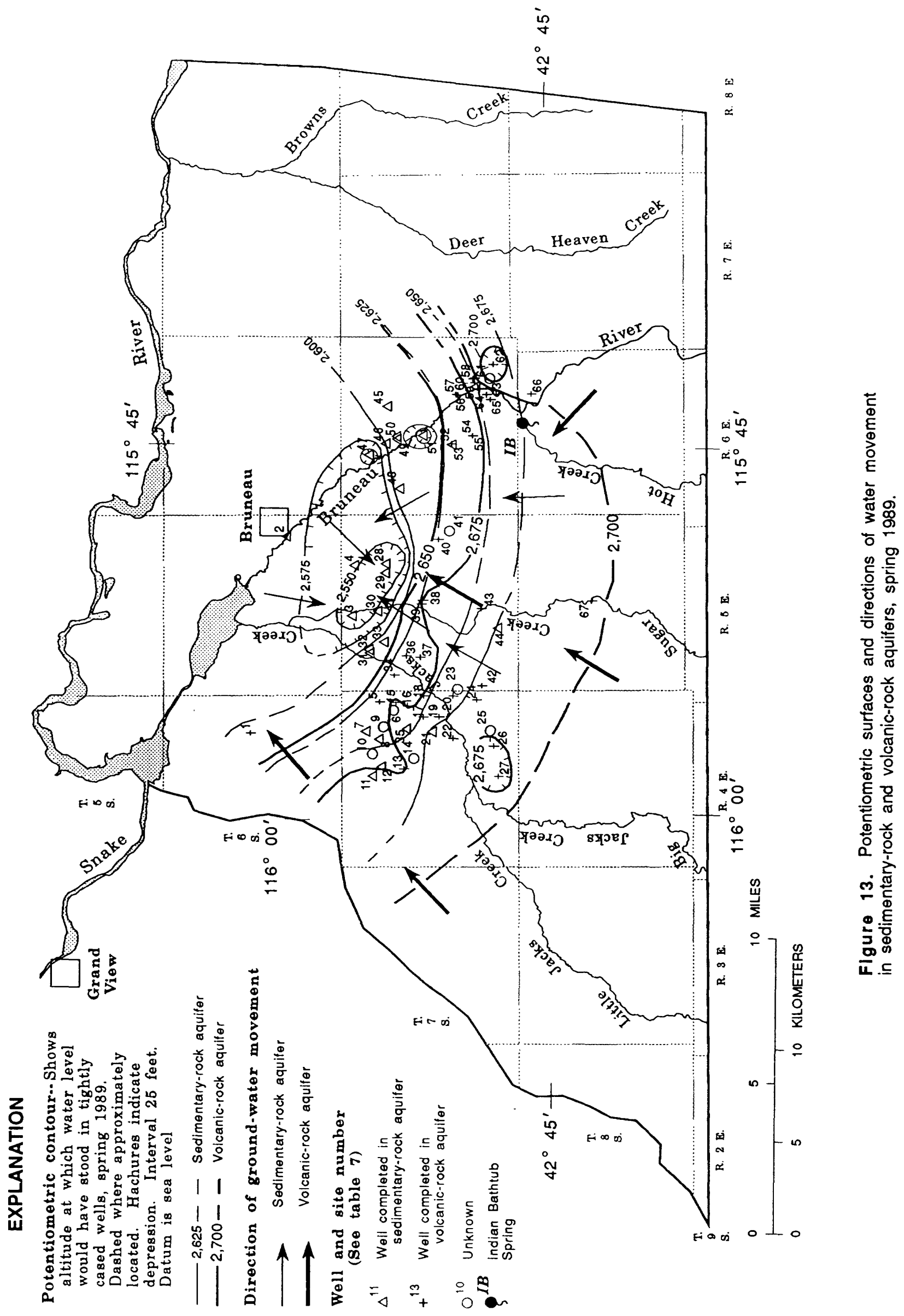


Table 7. Water-level measurements in selected wells, Bruneau study area, spring 1989

[Site No.: Indicates location of well in figure 13. Altitude of land surface and altitude of water level in feet above sea level. Depth of well, perforated interval, open hole, and depth to water in feet below land surface. Depth to water: $F$, well flowing above land surface; negative value indicates water level above land surface. Aquifer monitored: Sr, sedimentary-rock; Vr, volcanic-rock; U, unknown. Symbols: -, no data available]

\begin{tabular}{|c|c|c|c|c|c|c|c|c|c|}
\hline $\begin{array}{l}\text { Site } \\
\text { No. }\end{array}$ & Well No. & $\begin{array}{l}\text { Altitude } \\
\text { of land } \\
\text { surface }\end{array}$ & $\begin{array}{l}\text { Depth } \\
\text { of } \\
\text { well }\end{array}$ & $\begin{array}{l}\text { Perforated } \\
\text { Interval }\end{array}$ & $\begin{array}{l}\text { Open } \\
\text { hole }\end{array}$ & $\begin{array}{c}\text { Date } \\
\text { measured } \\
(1989)\end{array}$ & $\begin{array}{l}\text { Depth } \\
\text { to } \\
\text { water }\end{array}$ & $\begin{array}{c}\text { Altitude } \\
\text { of water } \\
\text { level }\end{array}$ & $\begin{array}{l}\text { Aqulfer } \\
\text { monitored }\end{array}$ \\
\hline 1 & $6 \mathrm{~S}-4 \mathrm{E}-14 \mathrm{ABCl}$ & 2.665 & 1,900 & - & - & $3-21$ & 42.94 & $2,622.06$ & $\mathrm{Vr}$ \\
\hline 2 & $6 S-5 E-24 B C A I$ & 2,525 & 1,095 & - & $75-1,095$ & $1-19$ & -56.80 & $2,581.80$ & $\mathrm{Sr}$ \\
\hline 3 & $6 \mathrm{~S}-5 \mathrm{E}-33 \mathrm{DBB}$ & 2,540 & 142 & - & _ & $3-21$ & 6.93 & $2,533.07$ & $\mathrm{Sr}$ \\
\hline 4 & $6 \mathrm{~S}-5 \mathrm{E}-35 \mathrm{CBD}$ & 2,620 & 476 & $230-350$ & $350-476$ & $3-22$ & 67.36 & $2,552.64$ & $\mathrm{Sr}$ \\
\hline 5 & $7 \mathrm{~S}-4 \mathrm{E}-\mathrm{IACCl}$ & 2,655 & 1,800 & - & - & $3-23$ & -8.02 & $2,663.02$ & $\mathrm{Vr}$ \\
\hline 6 & $7 \mathrm{~S}-4 \mathrm{E}-1 \mathrm{CDC} 1$ & 2,670 & - & - & - & $3-23$ & -.72 & 2.670 .72 & $\mathrm{U}$ \\
\hline 7 & $7 \mathrm{~S}-4 \mathrm{E}-2 \mathrm{ABBI}$ & 2,700 & 342 & - & $197-342$ & $3-30$ & 54.83 & $2,645.17$ & $\mathrm{Sr}$ \\
\hline 8 & $7 \mathrm{~S}-4 \mathrm{E}-2 \mathrm{CAB} 1$ & 2,675 & 890 & - & $330-890$ & $3-22$ & 31.17 & $2,643.83$ & $\mathrm{Sr}$ \\
\hline 9 & $7 \mathrm{~S}-4 \mathrm{E}-2 \mathrm{DBAl}$ & 2,675 & - & - & - & $3-23$ & -4.84 & $2,679.84$ & $\mathrm{U}$ \\
\hline 10 & $7 \mathrm{~S}-4 \mathrm{E}-3 \mathrm{AACl}$ & 2,730 & - & - & - & $3-22$ & 70.82 & $2,659.18$ & $U$ \\
\hline 11 & $7 S-4 E-3 B B C I$ & 2,770 & 1,050 & $100-538$ & $\begin{array}{l}538-600 \\
780-1.050\end{array}$ & $3-22$ & 107.29 & $2,662.71$ & $\mathrm{Sr}$ \\
\hline 12 & $7 \mathrm{~S}-4 \mathrm{E}-3 \mathrm{CABI}$ & 2,770 & 1,050 & $775-901$ & $901-1,050$ & $3-23$ & 106.67 & $2,663.33$ & $\mathrm{Sr}$ \\
\hline 13 & $7 \mathrm{~S}-4 \mathrm{E}-10 \mathrm{BDB}$ & 2,755 & 1,145 & $537-568$ & $\begin{array}{l}616-737 \\
738-1,145\end{array}$ & $3-21$ & 81.20 & $2,673.80$ & $\mathrm{Vr}$ \\
\hline 14 & 7S-4E-10DBDI & 2,740 & - & - & - & $3-21$ & 72.55 & $2,667.45$ & $U$ \\
\hline 15 & $7 \mathrm{~S}-4 \mathrm{E}-12 \mathrm{ABBI}$ & 2,660 & 1,600 & - & - & $3-23$ & -20.02 & $2,680.02$ & $\mathrm{Vr}$ \\
\hline 16 & $7 \mathrm{~S}-4 \mathrm{E}-12 \mathrm{BDDI}$ & 2,660 & 1,105 & - & $675-735$ & $3-23$ & -12.82 & $2,672.82$ & $\mathrm{Vr}$ \\
\hline 17 & $7 \mathrm{~S}-4 \mathrm{E}-12 \mathrm{CCC}$ & 2,700 & 900 & - & $475-900$ & $3-20$ & 10.88 & $2,689.12$ & $\mathrm{Vr}$ \\
\hline 18 & $7 \mathrm{~S}-4 \mathrm{E}-12 \mathrm{DDCl}$ & 2,660 & 1,350 & - & $339-1,350$ & $3-24$ & $\mathrm{~F}$ & - & $\mathrm{Vr}$ \\
\hline 19 & $7 \mathrm{~S}-4 \mathrm{E}-13 \mathrm{BCCl}$ & 2,690 & 1,060 & - & $194-1,060$ & $3-20$ & 12.92 & $2,677.08$ & $\mathrm{Vr}_{\mathrm{r}}$ \\
\hline 20 & $7 \mathrm{~S}-4 \mathrm{E}-13 \mathrm{DCD} 1$ & 2,670 & 1,000 & - & $194-1,000$ & $3-21$ & -9.42 & $2,679.42$ & $\mathrm{Vr}$ \\
\hline 21 & $7 \mathrm{~S}-4 \mathrm{E}-14 \mathrm{ABCl}$ & 2,725 & 1,146 & - & $223-1,146$ & $3-20$ & 47.78 & $2,677.22$ & $\mathrm{Sr}$ \\
\hline 22 & $7 \mathrm{~S}-4 \mathrm{E}-14 \mathrm{CDCl}$ & 2,755 & 950 & - & $200-950$ & $3-20$ & 75.94 & $2,679.06$ & $\mathrm{Vr}$ \\
\hline 23 & 7S-4E-24AAAI & 2,660 & - & - & - & $3-20$ & $\mathrm{~F}$ & - & $\mathrm{U}$ \\
\hline 24 & $7 \mathrm{~S}-4 \mathrm{E}-24 \mathrm{DCB} 1$ & 2,690 & 750 & - & - & $3-20$ & 21.85 & $2,668.15$ & $\mathrm{Vr}$ \\
\hline 25 & $7 \mathrm{~S}-4 \mathrm{E}-26 \mathrm{ACB} 1$ & 2,730 & - & - & - & $3-22$ & 56.82 & $2,673.18$ & $\mathrm{U}$ \\
\hline 26 & $7 \mathrm{~S}-4 \mathrm{E}-26 \mathrm{BCB} 1$ & 2,750 & 867 & $130-180$ & $180-867$ & $3-22$ & 72.35 & $2,677.65$ & $\mathrm{Vr}$ \\
\hline 27 & $7 \mathrm{~S}-4 \mathrm{E}-27 \mathrm{BCC}$ & 2,770 & 1,390 & - & $19-1,230$ & $3-21$ & 101.93 & $2,688.07$ & $\mathrm{Vr}$ \\
\hline 28 & $7 \mathrm{~S}-5 \mathrm{E}-2 \mathrm{CBDI}$ & 2,650 & 300 & $100-300$ & - & $3-22$ & 115.67 & $2,534.33$ & $\mathrm{Sr}$ \\
\hline 29 & $7 \mathrm{~S}-5 \mathrm{E}-3 \mathrm{DAD} 1$ & 2,640 & 300 & - & - & $3-22$ & 115.05 & $2,524.95$ & $\mathrm{Sr}$ \\
\hline 30 & $7 \mathrm{~S}-5 \mathrm{E}-4 \mathrm{ACDI}$ & 2,575 & 1,100 & - & $700-1,100$ & $3-23$ & 16.60 & $2,558.40$ & $\mathrm{Sr}$ \\
\hline 31 & $7 S-5 E-5 B A C I$ & 2,579 & 906 & - & - & $3-23$ & $\mathrm{~F}$ & - & $\mathrm{Sr}$ \\
\hline 32 & $7 \mathrm{~S}-5 \mathrm{E}-5 \mathrm{BAC} 2$ & 2,579 & 920 & - & - & $3-23$ & $\mathrm{~F}$ & - & $\mathrm{Sr}$ \\
\hline 33 & $7 \mathrm{~S}-5 \mathrm{E}-5 \mathrm{DBC} 1$ & 2,600 & 2,405 & $160-190$ & $651-747$ & $3-23$ & $\mathrm{~F}$ & - & $\mathrm{Sr}$ \\
\hline 34 & 7S-5E- 7ABBI & 2,615 & 1,625 & - & $632-1,625$ & $3-24$ & $\mathrm{~F}$ & - & $\mathrm{Vr}$ \\
\hline 35 & $7 \mathrm{~S}-5 \mathrm{E}-8 \mathrm{BBCl}$ & 2,594 & 580 & - & $140-580$ & $3-23$ & $\mathrm{~F}$ & - & $\mathrm{Sr}$ \\
\hline 36 & $7 S-5 E-8 B C C 1$ & 2,600 & 1,390 & - & $310-1,390$ & $3-23$ & -60.06 & $2,660.06$ & $\mathrm{Vr}$ \\
\hline 37 & $7 \mathrm{~S}-5 \mathrm{E}-\mathrm{8CCC1}$ & 2,640 & 1,500 & - & $\begin{array}{l}200-555 \\
690-1,500\end{array}$ & $3-23$ & -12.32 & $2,652.32$ & $\mathrm{Vr}$ \\
\hline 38 & $7 \mathrm{~S}-5 \mathrm{E}-9 \mathrm{DDCl}$ & 2,652 & 2,170 & - & $96-2,170$ & $3-22$ & $\mathrm{~F}$ & - & $\mathrm{Vr}$ \\
\hline 39 & 7S-5E- 9DDDI & 2,662 & 2,065 & - & $\begin{array}{l}550-984 \\
1,034-1,337 \\
1,624-1,925\end{array}$ & $3-22$ & -15.12 & $2,677.12$ & $\mathrm{Vr}$ \\
\hline 40 & $7 \mathrm{~S}-5 \mathrm{E}-13 \mathrm{CBB} 1$ & 2,771 & 1,954 & $\begin{array}{l}180-710 \\
1,070-1,180 \\
1,560-1,680\end{array}$ & $1,680-1,950$ & $3-22$ & 118.80 & $2,652.20$ & $\mathrm{Vr}$ \\
\hline 41 & $7 \mathrm{~S}-5 \mathrm{E}-13 \mathrm{CDB} 1$ & 2,790 & - & - & - & $3-21$ & 126.82 & $2,663.18$ & $\mathrm{U}$ \\
\hline 42 & $7 \mathrm{~S}-5 \mathrm{E}-19 \mathrm{CCCl}$ & 2,720 & 760 & - & $309-760$ & $3-21$ & 42.42 & $2,677.58$ & $\mathrm{Vr}$ \\
\hline 43 & $7 \mathrm{~S}-5 \mathrm{E}-21 \mathrm{CCA}$ & 2,763 & 1,135 & $406-706$ & - & $3-22$ & 77.25 & $2,685.75$ & $\mathrm{Vr}$ \\
\hline 44 & $7 \mathrm{~S}-5 \mathrm{E}-28 \mathrm{CBB} 1$ & 2,800 & 245 & - & $18-245$ & $3-22$ & 121.28 & $2,678.72$ & $\mathrm{Sr}$ \\
\hline 45 & $7 \mathrm{~S}-6 \mathrm{E}-3 \mathrm{DCB} 1$ & 2,675 & 1,510 & - & $304-1,510$ & $3-22$ & 44.68 & $2,630.32$ & $\mathrm{Sr}$ \\
\hline 46 & $7 \mathrm{~S}-6 \mathrm{E}-4 \mathrm{CDAI}$ & 2,598 & 1,040 & - & - & $3-21$ & -2.12 & $2,600.12$ & $\mathrm{Sr}$ \\
\hline 47 & 7S-6E- 5AADI & 2,570 & 158 & - & $80-158$ & $3-21$ & 30.08 & $2,539.92$ & $\mathrm{Sr}$ \\
\hline 48 & $7 \mathrm{~S}-6 \mathrm{E}-7 \mathrm{AACI}$ & 2,585 & 1,086 & - & $342-1,086$ & $3-22$ & $\mathrm{~F}$ & - & $\mathrm{Sr}$ \\
\hline 49 & $7 \mathrm{~S}-6 \mathrm{E}-9 \mathrm{BADI}$ & 2,580 & 910 & - & $42-910$ & $3-20$ & -32.12 & $2,612.12$ & $\mathrm{Sr}$ \\
\hline 50 & $7 S-6 E-9 B A D 2$ & 2,580 & 960 & - & $80-960$ & $3-20$ & -32.12 & $2,612.12$ & $\mathrm{Sr}$ \\
\hline
\end{tabular}


Table 7. Water-level measurements in selected wells, Bruneau study area, spring 1989-Continued

\begin{tabular}{|c|c|c|c|c|c|c|c|c|c|}
\hline $\begin{array}{l}\text { Site } \\
\text { No. }\end{array}$ & Well No. & $\begin{array}{l}\text { Altitude } \\
\text { of land } \\
\text { surface }\end{array}$ & $\begin{array}{c}\text { Depth } \\
\text { of } \\
\text { well }\end{array}$ & $\begin{array}{l}\text { Perforated } \\
\text { interval }\end{array}$ & $\begin{array}{l}\text { Open } \\
\text { hole }\end{array}$ & $\begin{array}{c}\text { Date } \\
\text { measured } \\
(1989)\end{array}$ & $\begin{array}{l}\text { Depth } \\
\text { to } \\
\text { water }\end{array}$ & $\begin{array}{c}\text { Altitude } \\
\text { of water } \\
\text { level }\end{array}$ & $\begin{array}{l}\text { Aquifer } \\
\text { monitored }\end{array}$ \\
\hline 51 & 7S-6E-16ABB2 & 2.553 & 1.980 & - & $158-190$ & $3-21$ & 5.00 & $2,548.00$ & $\mathrm{Sr}$ \\
\hline 52 & $7 \mathrm{~S}-6 \mathrm{E}-16 \mathrm{CDCl}$ & 2,595 & 513 & - & $389-513$ & $3-20$ & -73.52 & $2,668.52$ & $\mathrm{Vr}$ \\
\hline 53 & $7 \mathrm{~S}-6 \mathrm{E}-16 \mathrm{CDC} 2$ & 2,606 & 353 & - & $80-353$ & $3-20$ & -12.92 & 2.618 .92 & $\mathrm{Sr}$ \\
\hline 54 & $7 \mathrm{~S}-6 \mathrm{E}-21 \mathrm{DBC} 1$ & 2,631 & 760 & - & $167-760$ & $3-20$ & -36.94 & $2,667.94$ & $\mathrm{Vr}_{\mathrm{r}}$ \\
\hline 55 & $7 \mathrm{~S}-6 \mathrm{E}-21 \mathrm{DBC} 2$ & 2,635 & 611 & - & $167-611$ & $3-20$ & $\mathrm{~F}$ & - & $\mathrm{Vr}$ \\
\hline 56 & 7S-6E-22AADAI & 2,648 & 1,410 & - & $400-1,410$ & $3-21$ & $\mathrm{~F}$ & - & $\mathrm{Vr}$ \\
\hline 57 & 7S-6E-22AADA2 & 2,645 & 585 & - & - & $3-21$ & -19.42 & $2,664.42$ & $\mathrm{Vr}$ \\
\hline 58 & 7S-6E-23CADI & 2,675 & 1,300 & - & $40-900$ & $3-22$ & -19.72 & $2,694.72$ & $\mathrm{Vr}$ \\
\hline 59 & $7 \mathrm{~S}-6 \mathrm{E}-23 \mathrm{CCAI}$ & 2,625 & 460 & - & $107-460$ & $3-21$ & -17.62 & $2,642.62$ & $\mathrm{Sr}$ \\
\hline 60 & $7 \mathrm{~S}-6 \mathrm{E}-23 \mathrm{CDB} 1$ & 2,635 & 1,030 & - & $341-1,000$ & $3-22$ & $\mathrm{~F}$ & - & $\mathrm{Vr}$ \\
\hline 61 & 7S-6E-23DCB I & 2,710 & 1,220 & - & $365-1,220$ & $3-22$ & -7.92 & $2,717.92$ & $\mathrm{Vr}$ \\
\hline 62 & $7 \mathrm{~S}-6 \mathrm{E}-26 \mathrm{ADAl}$ & 2,700 & 1,000 & - & $171-1,000$ & $3-24$ & 16.84 & $2,683.16$ & $\mathrm{Vr}$ \\
\hline 63 & 7S-6E-26BDAl & 2,655 & - & - & - & $3-20$ & -42.72 & $2,697.72$ & U \\
\hline 64 & $7 S-6 E-27 A A D I$ & - & 350 & - & - & $3-22$ & $\mathrm{~F}$ & - & $V_{r}$ \\
\hline 65 & $7 \mathrm{~S}-6 \mathrm{E}-27 \mathrm{ADB}$ & 2,626 & 400 & - & - & $3-22$ & $\mathrm{~F}$ & - & $\mathrm{Vr}$ \\
\hline 66 & 7S-6E-34DADI & 2,725 & 300 & - & $46-300$ & $4-11$ & -9.18 & $2,734.18$ & $\mathrm{Vr}$ \\
\hline 67 & $8 \mathrm{~S}-5 \mathrm{E}-16 \mathrm{AAAI}$ & 3,010 & 410 & - & - & $5-16$ & 321.40 & $2,688.60$ & $\mathrm{Vr}$ \\
\hline
\end{tabular}

Potentiometric contours for both the sedimentary- and volcanic-rock aquifers (fig. 13) were constructed from water-level measurements (table 7) made during nonpumping periods in spring 1989. Wells open to both the sedimentaryand volcanic-rock aquifers were treated as if they were completed in the volcanic-rock aquifer (see section, "Ground-Water Development").

Ground-water movement in both the sedimentary- and volcanic-rock aquifers in spring 1989 generally was from south to north toward the Snake River. The altitude of hydraulic head in the sedimentary-rock aquifer ranges from about $2,525 \mathrm{ft}$ above sea level as indicated by the water level in well 7S-5E-3DAD1 to 2,680 ft above sea level as indicated by the water level in well 7S-5E$28 \mathrm{CBB} 1$. Hydraulic head in the volcanic-rock aquifer ranges from about $2,622 \mathrm{ft}$ above sea level as indicated by the water level in well $6 \mathrm{~S}-4 \mathrm{E}$ $14 \mathrm{ABC} 1$ to $2,735 \mathrm{ft}$ above sea level as indicated by the water level in well 7S-6E-34DAD1 (table 7). The average water-surface gradient is about $20 \mathrm{ft} / \mathrm{mi}$ toward the north in the sedimentary-rock aquifer and about $10 \mathrm{ft} / \mathrm{mi}$ toward the north in the volcanic-rock aquifer.

Spring 1989 potentiometric surfaces for the sedimentary- and volcanic-rock aquifers show four distinct cones of depression. In the northern part of the study area, from Bruneau Valley to Sugar Valley, a cone of depression has developed around irrigation wells completed in the sedimentary-rock aquifer. The large areal extent of this depression may reflect a long-term water-level decline due to withdrawals. A smaller depression in Bruneau Valley is centered around well 7S-6E-16ABB2. In these depressions, well discharge caused water levels to decline below $2,550 \mathrm{ft}$ in altitude and reversed the direction of ground-water movement from north to south (fig. 13). Two small cones of depression on the spring 1989 surface are related to withdrawals from the volcanic-rock aquifer (fig. 13), one in Bruneau Valley and the other in Little Valley. These two depressions are near the southern end of each valley, where volcanic rocks are close to land surface and sedimentary rocks are thin (fig. 3).

Water is under artesian pressure in both the sedimentary- and volcanic-rock aquifers. Hydraulic head is as much as $50 \mathrm{ft}$ higher in the volcanicrock aquifer than in the sedimentary-rock aquifer in parts of Bruneau Valley, although differences are typically about $25 \mathrm{ft}$ in most of the study area (fig. 13). Water-level data from three paired wells (table 8) also are used to demonstrate hydraulic head increases with depth throughout the study area. In each pair, the water level in wells completed in the volcanic-rock aquifer is higher than the water level in wells completed in the sedimentary-rock aquifer. This water level indicates that hydraulic head increases with depth from the sedi- 
Table 8. Hydraulic heads and potential for vertical ground-water movement in paired wells

[Altitude of land surface and altitude of hydraulic head in feet above sea level. Depth of well and perforated interval or open hole in feet below land surface. Aquifer monitored: Sr. sedımentary-rock; $V_{r}$, volcanic-rockl

\begin{tabular}{|c|c|c|c|c|c|c|c|c|}
\hline Well No. & $\begin{array}{l}\text { Altitude } \\
\text { of land } \\
\text { surface }\end{array}$ & $\begin{array}{c}\text { Depth } \\
\text { of } \\
\text { well }\end{array}$ & $\begin{array}{l}\text { Perforated } \\
\text { interval or } \\
\text { open hole }\end{array}$ & $\begin{array}{l}\text { Aquifer } \\
\text { monitored }\end{array}$ & $\begin{array}{c}\text { Date } \\
\text { measured }\end{array}$ & $\begin{array}{c}\text { Altitude } \\
\text { of } \\
\text { hydraulic } \\
\text { head }\end{array}$ & $\begin{array}{l}\text { Hydraulic } \\
\text { head } \\
\text { difference } \\
\text { between } \\
\text { units }\end{array}$ & $\begin{array}{l}\text { Potential } \\
\text { vertical } \\
\text { direction of } \\
\text { ground-water } \\
\text { movement }\end{array}$ \\
\hline \multicolumn{9}{|l|}{ Bruneau Valley } \\
\hline $7 S-6 E-16 C D C 1$ & 2,595 & 513 & $389-513$ & $\mathrm{~V}_{\mathrm{r}}$ & $3-20-89$ & $2,668.52$ & & \\
\hline $7 S-6 E-16 C D C 2$ & 2,606 & 353 & $80-353$ & Sr & $3-20-89$ & $2,618.92$ & 39.60 & Upward \\
\hline \multicolumn{9}{|c|}{ Near Indian Bathtub Spring } \\
\hline 7S-6E-29BBAI & $2,832.5$ & 760 & $415-760$ & $\mathrm{Vr}$ & $5-23-90$ & $2,675.83$ & & \\
\hline $7 S-6 E-29 B B A 2$ & $2,832.5$ & 364 & $246-364$ & $\mathrm{Sr}$ & $5-23-90$ & $2,646.95$ & 28.88 & Upward \\
\hline \multicolumn{9}{|l|}{ Little Valley } \\
\hline $7 S-4 E-I 0 B D B I$ & 2,755 & 1,145 & $\begin{array}{l}537-568 \\
616-737 \\
738-1,145\end{array}$ & $\mathrm{Vr}$ & $3-21-89$ & $2,673.80$ & & \\
\hline $7 \mathrm{~S}-4 \mathrm{E}-2 \mathrm{CAB}$ & 2,675 & 890 & $330-890$ & $\mathrm{Sr}$ & $3-22-89$ & $2,643.83$ & 29.97 & Upward \\
\hline
\end{tabular}

mentary-rock aquifer to the volcanic-rock aquifer, and water moves upward from the volcanic-rock aquifer into the sedimentary-rock aquifer.

The Bruneau area is intensively faulted, as indicated by geologic data (figs. 2 and 4). Previous investigators (Piper, 1924; Littleton and Crosthwaite, 1957; Young and Whitehead, 1975; Young and Lewis, 1982) believed that many faults and fractures are not barriers to water movement but instead provide conduits for ground-water flow, horizontally and vertically. Data collected during this study did not indicate abnormal water-level differences across any of the known faults in the study area. Additional study is needed to determine geologic controls on water movement in the study area.

\section{Conceptualization of the Geothermal Aquifer System}

As described in preceding sections of this report, the ground-water system is a thick reservoir of sedimentary rocks (alluvial and lacustrine) and underlying volcanic rocks (fig. 14A). Sedimentary rocks are present in the northern and central parts of the study area and consist mainly of silt and clay with lesser amounts of sand. Sedimentary rocks are much less permeable than the volcanic rocks; their grain size and permeability decreases northward. The water table in these sediments is generally less than $100 \mathrm{ft}$ below land surface and is shallowest near major streams. In most of the area, the water table is undefined. Water in the deeper parts of the sedimentary rocks is confined by interbedded silt and clay, and hydraulic head increases with depth due to regional discharge. Water-bearing properties of the volcanic rocks vary and are dependent largely on the amount of fracturing and faulting. Generally, volcanic rocks are more permeable than sedimentary rocks; their permeability decreases southward. Water in volcanic rocks is confined where the rocks are dense and finegrained sedimentary interbeds are present. Water levels in wells in the volcanic rocks vary with depth of perforated interval or open section.

The ground-water reservoir underlying the Bruneau area functions as a three-dimensional flow system. Generally, water flows northward from the areas of recharge in and around the Jarbidge and Owyhee Mountains toward the study area, where it is discharged as springs and as seepage to streams or leaves the study area as ground-water underflow (fig. 14A). In recharge areas, there is a downward 


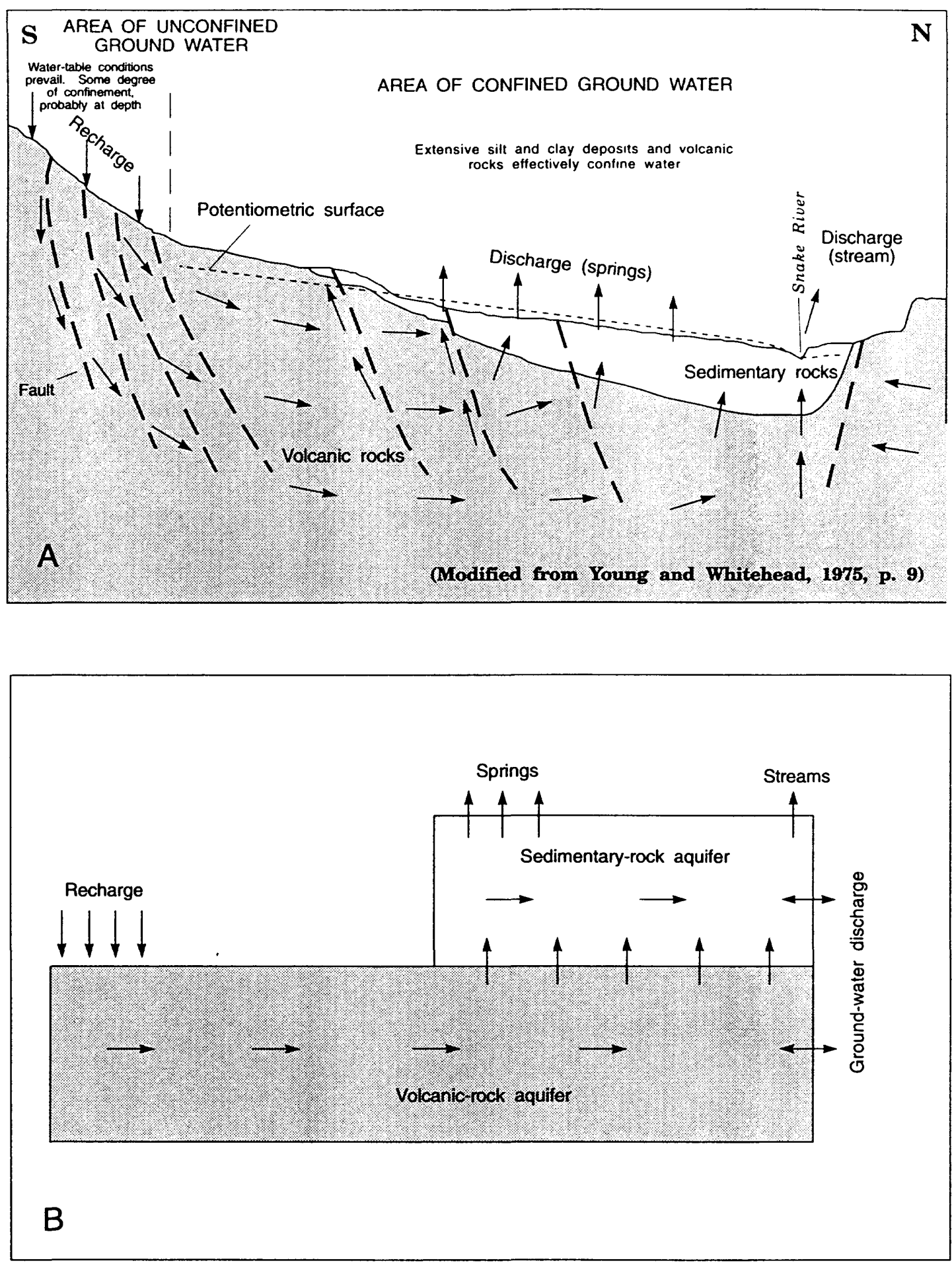

Figure 14. Conceptualization of the regional geothermal aquifer system in the Bruneau study area. A, Diagrammatic section. B, Conceptual model. (Arrows show direction of ground-water movement) 
component of water movement; in discharge areas, there is an upward component (fig. 14). Consequently, head varies both areally and with depth, and a multiple-layer concept is required to reasonably represent the regional geothermal aquifer system.

In this study, the ground-water system in the Bruneau area was treated as a two-layer system consisting of sedimentary rocks and volcanic rocks, which together compose the regional geothermal aquifer system (fig. 14B). Sedimentary rocks predominate in the northern and central parts of the study area and generally extend from about 100 to $2,000 \mathrm{ft}$ below land surface. Volcanic rocks predominate in the southern part of the study area and underlie sedimentary rocks in the northern part. Thickness of the volcanic rocks is not known but is probably 2,000 to $3,000 \mathrm{ft}$ (Young and Lewis, 1982, p. J17).

\section{EFFECTS OF DEVELOPMENT}

From the late 1890's through 1991, nearly $1,400,000$ acre-ft of water was discharged from flowing and pumped wells completed in the geothermal system in the study area, and about 275,000 acre-ft discharged from Indian Bathtub Spring. Of these quantities, about 546,000 acre-ft was discharged by wells and 2,000 acre-ft was spring flow during 1978-91. Most water discharged from wells, about 339,000 acre-ft, was from the volcanicrock aquifer. Of this quantity, about 78,000 , 218,000 , and 43,000 acre- $\mathrm{ft}$ were from wells in Bruneau, Little, and Sugar Valleys, respectively.

Response of the ground-water system to pumpage stress is complex. The two most apparent effects are declines in hydraulic head and declines in spring discharge.

\section{Declines in Hydraulic Head}

Hydraulic heads in the geothermal aquifer generally have declined since measure- ments began in the mid-1950's. The annual rate of decline and the net change in head between 1977 and 1989, when measurements of water levels in a large number of wells were made, vary areally depending on the degree and distribution of pumpage (figs. 7 and 9) and the hydraulic properties of the aquifer (see section "Hydraulic Characteristics"). Hydrographs of head changes in eight wells illustrate typical rates and magnitudes of change in various parts of the study area. Hydrographs for wells open only to the sedimentary-rock aquifer are shown in figure 15; hydrographs for wells open to the volcanic-rock aquifer are shown in figure 16.

Hydrographs for wells completed in the sedimentary-rock aquifer indicate small longterm changes in water levels. Annual fluctuations in water levels are mainly aquifer response to pumpage for irrigation. The hydrograph for well $6 \mathrm{~S}-5 \mathrm{E}-24 \mathrm{BCA} 1$ indicates that water levels declined slowly from the early 1960's to 1977 , probably owing to a gradual increase in pumpage, and later rose as pumpage decreased. Thirty percent of the total discharge in Little and Sugar Valleys is from wells open only to the sedimentary-rock aquifer; most wells are in the northern part of the study area. During the 1990-91 nonirrigation season, the water level in well 6S-5E-33DBB1 declined about $6 \mathrm{ft}$. The large decline probably was due to pumping of this well or nearby wells. The water level in well 7S-6E-9BAD2 in Bruneau Valley declined slowly until 1986, then the rate of decline accelerated in spite of the decline in pumpage.

Hydrographs for wells completed in the volcanic-rock aquifer indicate large long-term changes (decreases) in hydraulic head in the aquifer (fig. 16). No long-term water-level data are available for such wells in Sugar Valley. Wells 6S-4E-14ABC1, 7S-5E-18BCD1, and 7S-5E-19CCC1 in Little Valley, where pumpage since 1954 has been the greatest, exhibit large water-level declines. The hydrograph for well $6 \mathrm{~S}-4 \mathrm{E}-14 \mathrm{ABC} 1$, an irrigation well, shows that the water level declined about 


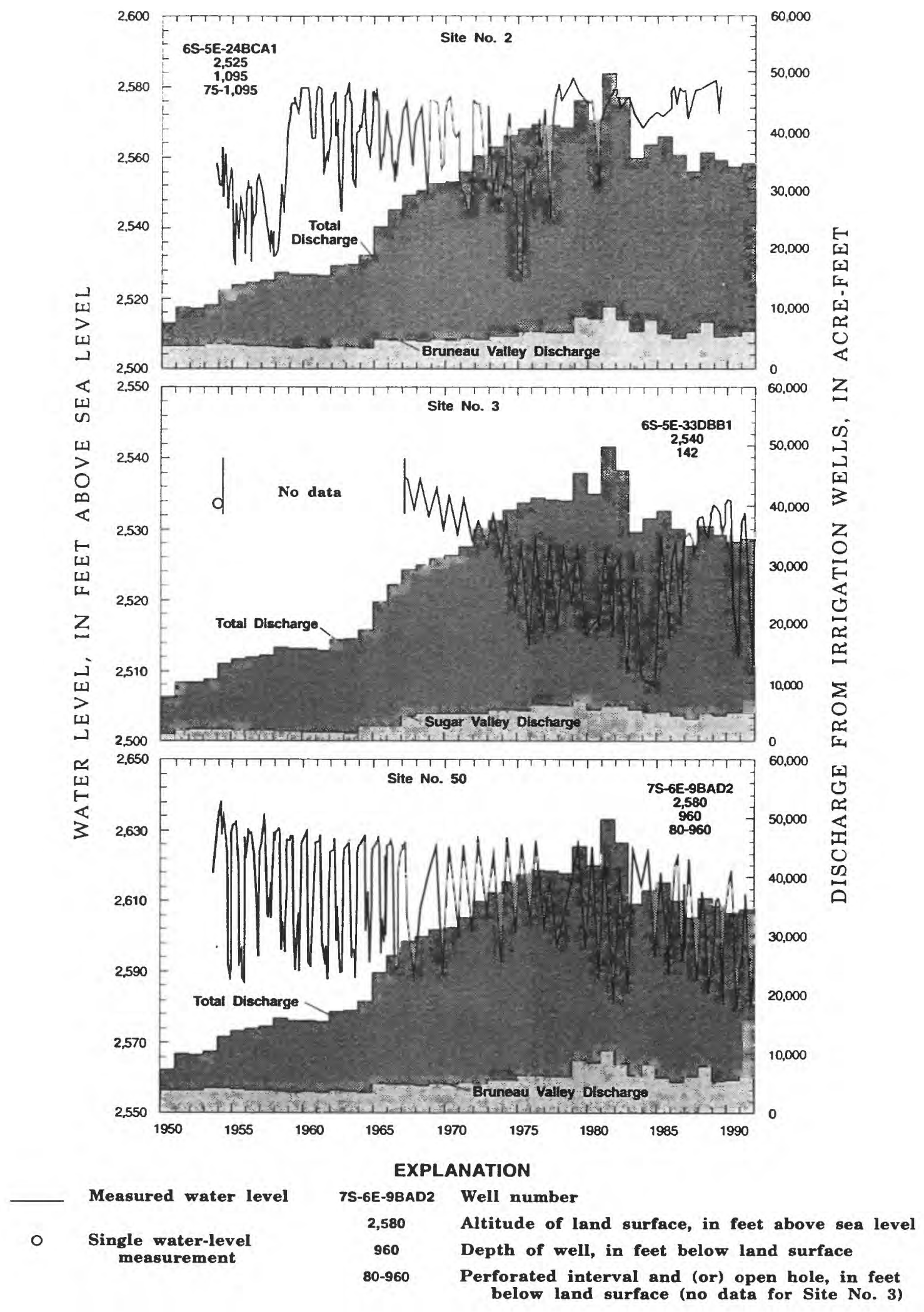

Figure 15. Hydrographs for wells completed in the sedimentary-rock aquifer. (Site numbers refer to table 7 and fig. 13) 


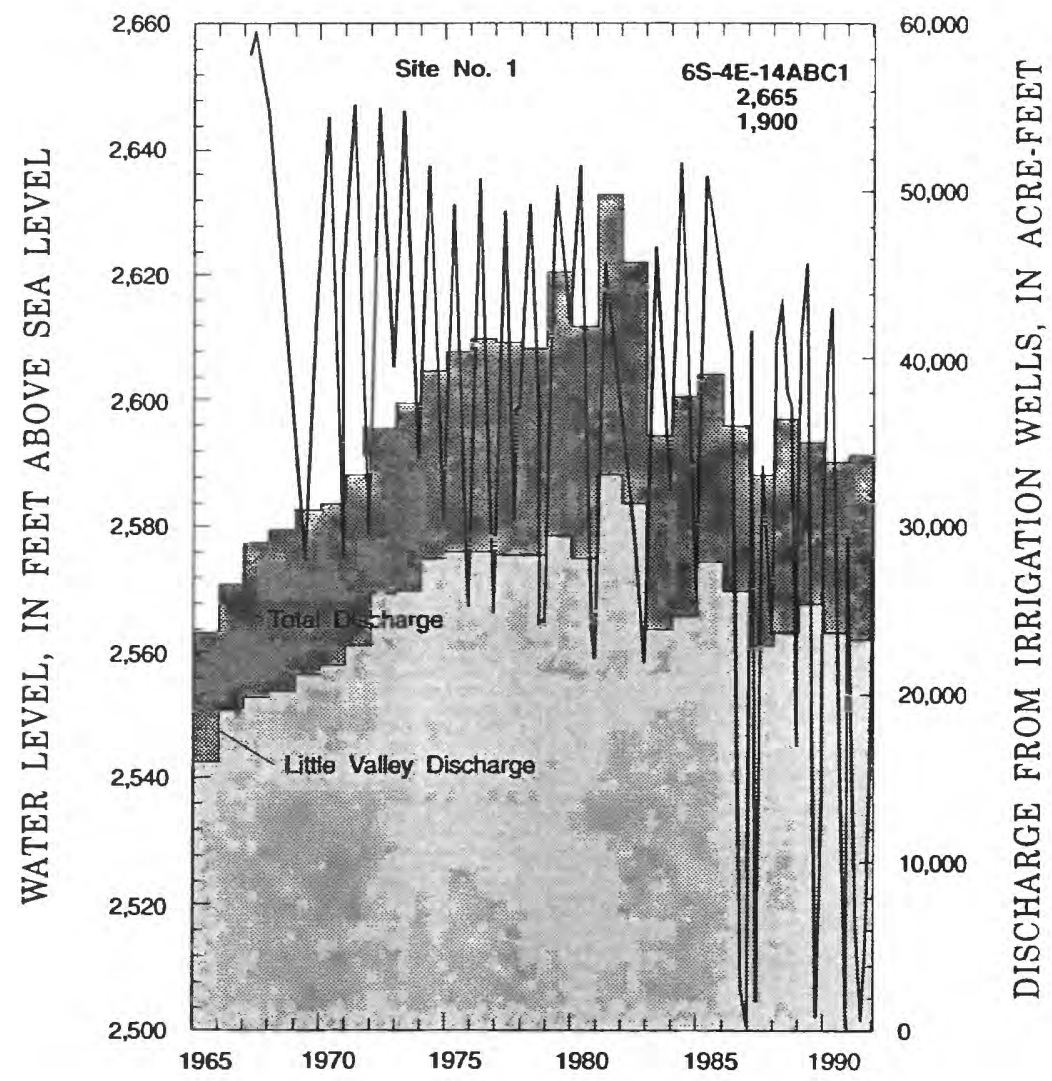

EXPLANATION

\begin{tabular}{cl}
\hline 0 & Measured water level \\
$7 S-5 E-19 C c C 1$ & Single water-level measurement \\
2,720 & $\begin{array}{l}\text { Altitude of land surface, in } \\
\text { feet above sea level }\end{array}$ \\
760 & $\begin{array}{l}\text { Depth of well, in feet below } \\
\text { land surface (no data for } \\
\text { Site No. 63) }\end{array}$ \\
& $\begin{array}{l}\text { Perforated interval and (or) } \\
\text { open hole, in feet below } \\
\text { land surface (no data for } \\
\text { Site Nos. } 1 \text { and 63) }\end{array}$
\end{tabular}

Figure 16. Hydrographs for wells completed in the volcanic-rock aquifer. (Site numbers refer to table 7 and fig. 13) 


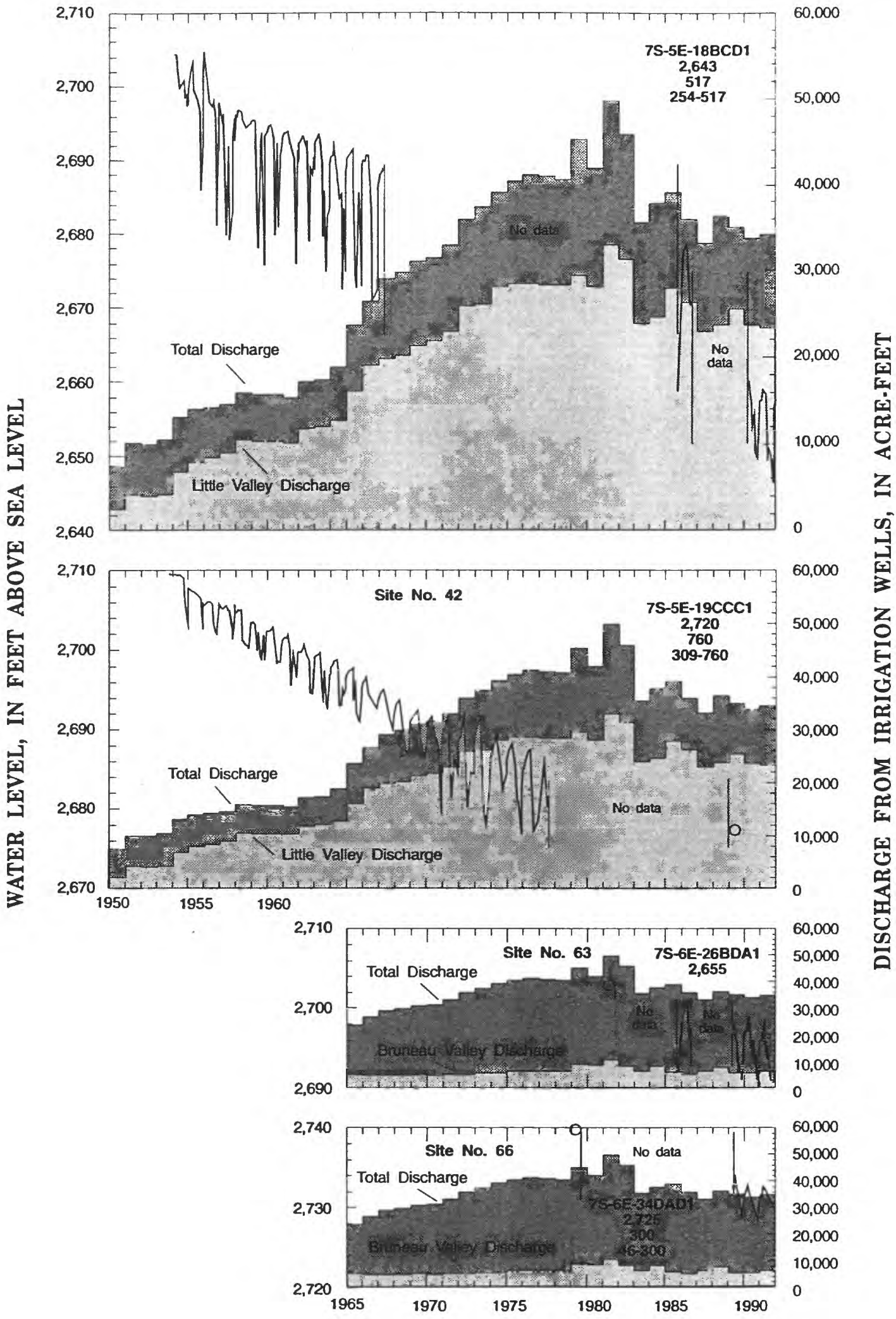

Figure 16. Hydrographs for wells completed in the volcanic-rock aquifer-Continued. 
$70 \mathrm{ft}$ from 1967 to 1991 . Water level in this well is generally inversely proportional to total pumpage and pumpage in Little Valley, except for 1986-91, when pumpage declined, as did hydraulic head. During the nonirrigation season, water level was about $30 \mathrm{ft}$ lower in the early 1990's than in the late 1980 's because pumpage from this well increased fourfold to about 1,400 acre-ft/yr. The large waterlevel changes between irrigation and nonirrigation seasons indicate that the specific capacity for this well is probably low and hydraulic conductivity of the volcanic rocks in this area is accordingly low. The water level in well 7S-5E-18BCDl declined about $45 \mathrm{ft}$ from 1954 to 1991 . The rate of decline was about $0.8 \mathrm{ft} / \mathrm{yr}$ during 1954-85, compared with $4.0 \mathrm{ft} / \mathrm{yr}$ during 1986-91. These rates of decline were based on the highest water-level values in 1954, 1986, and 1991. The reason for the increased rate is unknown because discharge from wells in Little Valley and total discharge from flowing and pumped wells in the study area have been relatively constant since 1983 . From 1950 to 1983, well discharge in Little Valley increased gradually. The water level in well 7S-5E-19CCC1, about $1.5 \mathrm{mi}$ south of well 7S-5E-18BCD1, declined steadily after 1953. Pumpage from this well was estimated to be about 500 acre-ft in 1954 (Littleton and Crosthwaite, 1957, p. 174, 188); 400 acre-ft in 1978 (Young and others, 1979, p. 3-4, 12); and averaged about 300 acre-ft during 1979-91. The rate of water-level decline in this well, based on the highest levels in 1953 and 1977 , was slightly less than $1 \mathrm{ft} / \mathrm{yr}$. On the basis of highest water-level measurements in 1977 and a single measurement in 1989, the rate of decline has decreased; during that time, total pumpage decreased about 500 acre-ft/yr.

Two hydrographs are used to show the intermediate effects of ground-water development in Bruneau Valley, although the earliest data are for 1979. The hydrograph for well 7S-6E-26BDA1 (fig. 16), an irrigation well, shows that the water level declined about $5 \mathrm{ft}$, or about $0.5 \mathrm{ft} / \mathrm{yr}$ during 1981-91. The steady decline can be related to the relatively steady pumpage in Bruneau Valley during this period. The water level in irrigation well 7S-6E-34DAD1, about $1 \mathrm{mi}$ from Indian Bathtub Spring, declined about $8 \mathrm{ft}$ since 1979 , or about 0.7 $\mathrm{ft} / \mathrm{yr}$. Although wells 7S-6E-34DADl and 7S-6E26BDA 1 are about $2 \mathrm{mi}$ apart, water levels in both

Table 9. Spring 1979, 1989, and 1992 hydraulic head measurements and head declines since 1979 at selected wells in the Bruneau study area

[Altitude of land surface and altitude of hydraulic head in feet above sea level. Head declines since spring 1979 in feet. Symbols: -, no data available]

\begin{tabular}{|c|c|c|c|c|c|c|c|c|c|}
\hline \multirow[b]{2}{*}{ Well No. } & \multirow[b]{2}{*}{$\begin{array}{l}\text { Altitude } \\
\text { of } \\
\text { land } \\
\text { surface }\end{array}$} & \multicolumn{2}{|c|}{$\begin{array}{c}\text { Spring } 1979 \\
\text { (Young and Lewis, 1982) }\end{array}$} & \multicolumn{3}{|c|}{ Spring 1989} & \multicolumn{3}{|c|}{ Spring 1992} \\
\hline & & $\begin{array}{l}\text { Date } \\
\text { measured }\end{array}$ & $\begin{array}{l}\text { Altitude of } \\
\text { hydraulic } \\
\text { head }\end{array}$ & $\begin{array}{l}\text { Date } \\
\text { measured }\end{array}$ & $\begin{array}{l}\text { Altitude of } \\
\text { hydraulic } \\
\text { head }\end{array}$ & $\begin{array}{c}\text { Head } \\
\text { declines since } \\
\text { spring } 1979\end{array}$ & $\begin{array}{l}\text { Date } \\
\text { measured }\end{array}$ & $\begin{array}{l}\text { Altitude of } \\
\text { hydraulic } \\
\text { head }\end{array}$ & $\begin{array}{c}\text { Head } \\
\text { declines since } \\
\text { spring } 1979\end{array}$ \\
\hline \multicolumn{10}{|l|}{ Aquifer unknown } \\
\hline $7 \mathrm{~S}-4 \mathrm{E}-1 \mathrm{CDCl}$ & 2,670 & $3-31$ & $2,676.82$ & $3-23$ & $2,670.72$ & 6.10 & - & - & - \\
\hline \multicolumn{10}{|c|}{ Sedimentary-rock aquifer } \\
\hline 7S-6E-9BAD2 & 2,580 & $3-15$ & $2,626.42$ & $3-20$ & $2,612.12$ & 14.30 & $2-19$ & $2,609.10$ & 17.32 \\
\hline \multicolumn{10}{|c|}{ Volcanic-rock aquifer } \\
\hline $6 \mathrm{~S}-4 \mathrm{E}-14 \mathrm{ABCl}$ & 2,665 & $3-13$ & $2,628.56$ & $3-21$ & $2,622.06$ & 6.50 & $1-28$ & $2,604.74$ & 23.82 \\
\hline $7 \mathrm{~S}-4 \mathrm{E}-10 \mathrm{BDB} 1$ & 2,755 & $3-14$ & $2,678.08$ & $3-21$ & $2,673.80$ & 4.28 & - & - & - \\
\hline $7 \mathrm{~S}-4 \mathrm{E}-27 \mathrm{BCCl}$ & 2,770 & $3-14$ & $2,675.00$ & $3-21$ & $2,668.07$ & 6.93 & $2-19$ & $2,664.95$ & 10.05 \\
\hline $7 \mathrm{~S}-5 \mathrm{E}-13 \mathrm{CBB} 1$ & 2,771 & $3-15$ & $2,657.78$ & $3-22$ & $2,652.20$ & 5.58 & $2-19$ & 2.665 .56 & 7.78 \\
\hline $7 \mathrm{~S}-6 \mathrm{E}-16 \mathrm{CDC1}$ & 2,595 & $3-15$ & 2,667 & $3-20$ & $2,668.52$ & 1.52 & $2-11$ & $2,666.88$ & .12 \\
\hline 7S-6E-34DAD1 & 2,725 & $3-15$ & $2,739.92$ & $4-11$ & $2,734.18$ & 5.74 & $2-19$ & 2.730 .60 & 9.32 \\
\hline
\end{tabular}


exhibited nearly the same rate of decline. Hydraulic heads in and around Indian Bathtub Spring probably decline at about the same rate as the water levels in wells 7S-6E-34DAD1 and 7S-6E-26BDA 1 , because these wells and the test holes near Indian Bathtub Spring have had about the same rate of decline since 1990 . The only exception to the generally declining heads appears to be in wells open to the sedimentary-rock aquifer.

An attempt was made to remeasure water levels in all wells measured in 1979 by Young and Lewis (1982) to show the effects of recent ground-water pumpage on hydraulic heads. Only a general comparison between the 1979 (Young and Lewis, 1982, pl. 2) and 1989 (fig. 13) potentiometric surfaces was possible because of the $100-\mathrm{ft}$ contour interval on the 1979 map and consequent differences in detail. Although more water levels were measured in 1989 , control for both maps was still sparse in much of the study area. Many of the wells measured in 1979 could not be remeasured in 1989 because they had been destroyed or for some other reason were no longer measurable. Only eight wells measured in 1979 were remeasured during this study. Of these, one well, 7S-6E-9BAD2, is open only to the sedimentary-rock aquifer (table 9). The water level in that well, about $1 \mathrm{mi}$ south of the depression on the potentiometric surface shown in figure 13 , declined $14.30 \mathrm{ft}$ and $17.32 \mathrm{ft}$ during 1979-89 and 1979-92, respectively.

Six of the eight wells remeasured in 1989 are completed in the volcanic-rock aquifer (table 9). During 1979-89, the water levels in five of the wells declined more than $4 \mathrm{ft}$, and the water level in one well rose $1.52 \mathrm{ft}$. The water level in well $6 \mathrm{~S}-4 \mathrm{E}-14 \mathrm{ABC} 1$ in the northern part of Little Valley declined $6.50 \mathrm{ft}$ and $23.82 \mathrm{ft}$ during 1979-89 and 1979-92, respectively. Declines were steeper between 1989 and 1992 when pumpage from this well increased fourfold. The water level in well 7S6E-34DAD1 declined $5.74 \mathrm{ft}$ by 1989 and 9.32 ft by 1992 (table 9), or about $0.7 \mathrm{ft} / \mathrm{yr}$ (fig. 16).
The water levels in wells 7S-4E-27BCCl and $7 \mathrm{~S}-6 \mathrm{E}-16 \mathrm{CDCl}$ declined $10.05 \mathrm{ft}$ and $0.12 \mathrm{ft}$ between 1979 and 1992, respectively. The water level in well 7S-5E-13CBB 1 rose more than $13 \mathrm{ft}$ between 1989 and 1992 because it was not pumped, as opposed to previous years of pumping.

During the second phase of this study, eight test holes at four sites near Indian Bathtub Spring were equipped with recorders to obtain continuous water-level measurements. The test hole at 7S-6E-29BBAl was completed to monitor water levels at two different depths to determine the vertical distribution of hydraulic head. Hydrographs for the test holes are shown in figure 17. Water levels fluctuate seasonally and are highest in MarchApril and lowest in September-October. Seasonal fluctuations are, in part, due to irrigation pumpage. Water levels declined about $5 \mathrm{ft}$ during the 1990 irrigation season, recovered to April 1990 levels prior to the start of the 1991 irrigation season, and declined about $6 \mathrm{ft}$ during the 1991 irrigation season. Following the 1991 irrigation season, water levels did not recover to April 1990 levels and were 1 to $2 \mathrm{ft}$ lower in spring 1992 than they were in spring 1991. Water levels changed less in test hole $7 \mathrm{~S}-6 \mathrm{E}-29 \mathrm{BBA} 2$ because it is open only to the sedimentary rocks, and about 10 percent of the ground-water discharge in Bruneau Valley is from the sedimentary rocks. In test hole 8S-6E-3BDC3, water levels did not rise as high or decline as low as in the other test holes because this test hole is open to $20 \mathrm{ft}$ of basalt between $10-\mathrm{ft}$ intervals of fine-grained rocks. The fine-grained rocks confine water in the basalt and cause delayed and attenuated responses from pumpage in aquifers below or above such units (see sections, "Slug Tests" and "Potentiometric Surfaces and Water Movement"). Hydrographs for the test holes (fig. 17) show that hydraulic head, even in nonstressed areas, is highly sensitive to well discharge.

Throughout the study area, hydraulic head responds to stress in a similar manner. Declines in head are the result of regional 


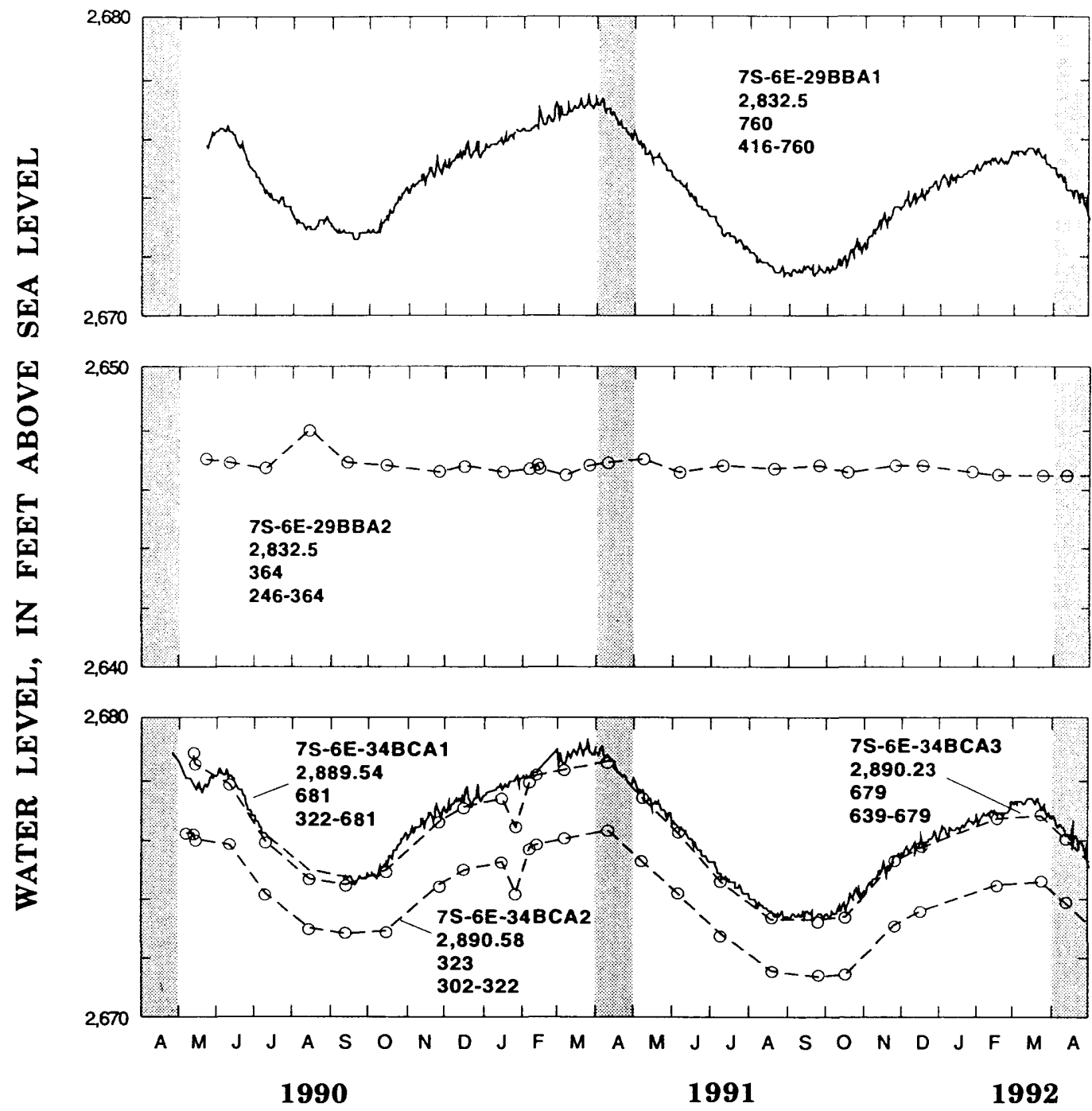

EXPLANATION

$\begin{array}{cl}-- & \begin{array}{c}\text { Measured/estimated hydraulic head } \\ \text { line indicates head from contin } \\ \text { recorder. Dashed line indicate } \\ \text { measured at least monthly }\end{array} \\ 0 & \text { Single water-level measurement } \\ 7 \text { S-6E-34BCA2 } & \text { Test hole } \\ 2,890.58 & \begin{array}{c}\text { Altitude of land surface, in } \\ \text { feet above sea level }\end{array} \\ 323 & \begin{array}{l}\text { Depth of well, in feet below } \\ \text { land surface }\end{array} \\ 302-322 & \begin{array}{c}\text { Open hole, in feet below land } \\ \text { surface }\end{array}\end{array}$

Figure 17. Hydrographs for test holes near Indian Bathtub Spring, April 1990 through April 1992. 


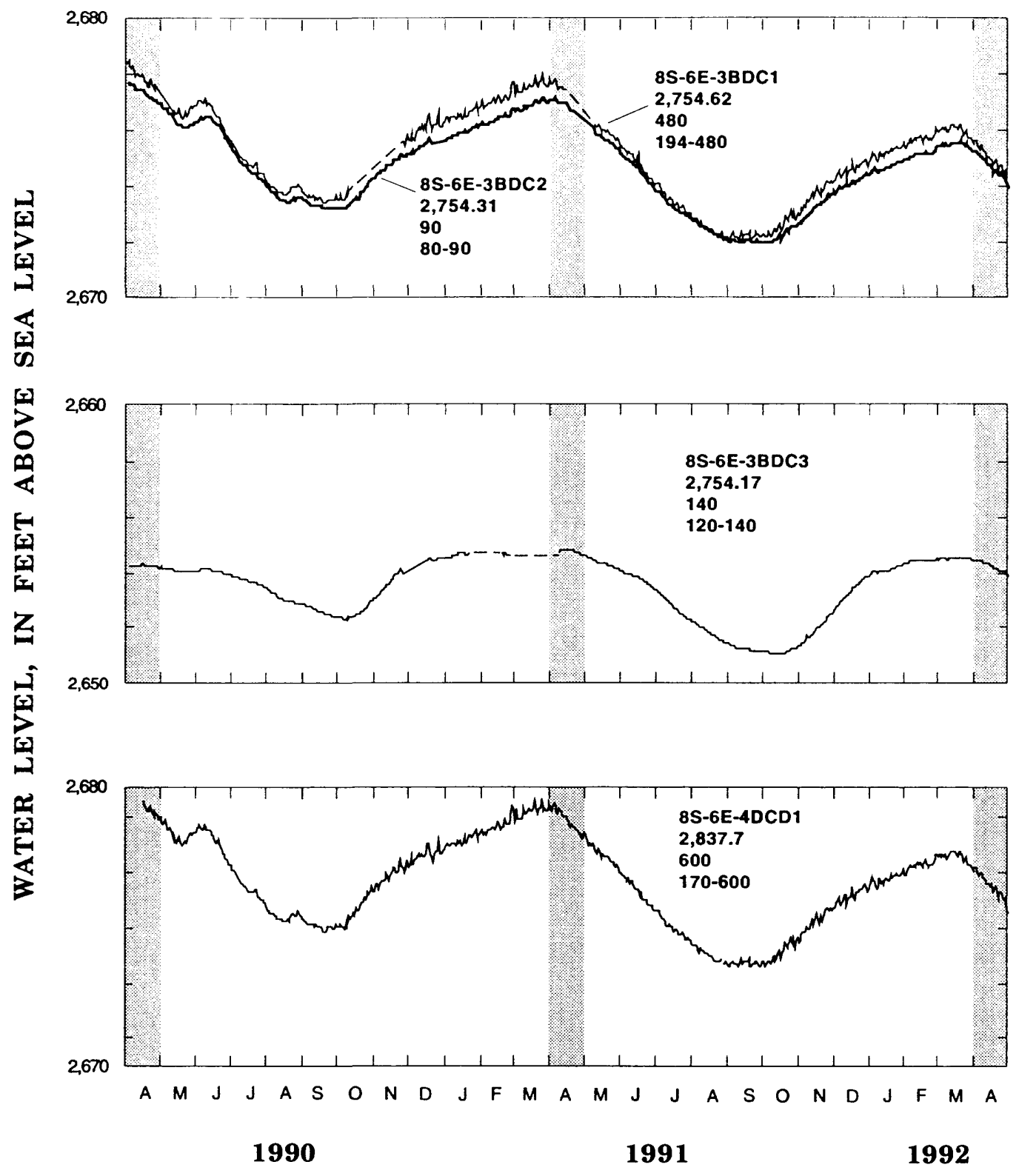

Figure 17. Hydrographs for test holes near Indian Bathtub Spring, April 1990 through April 1992-Continued. 


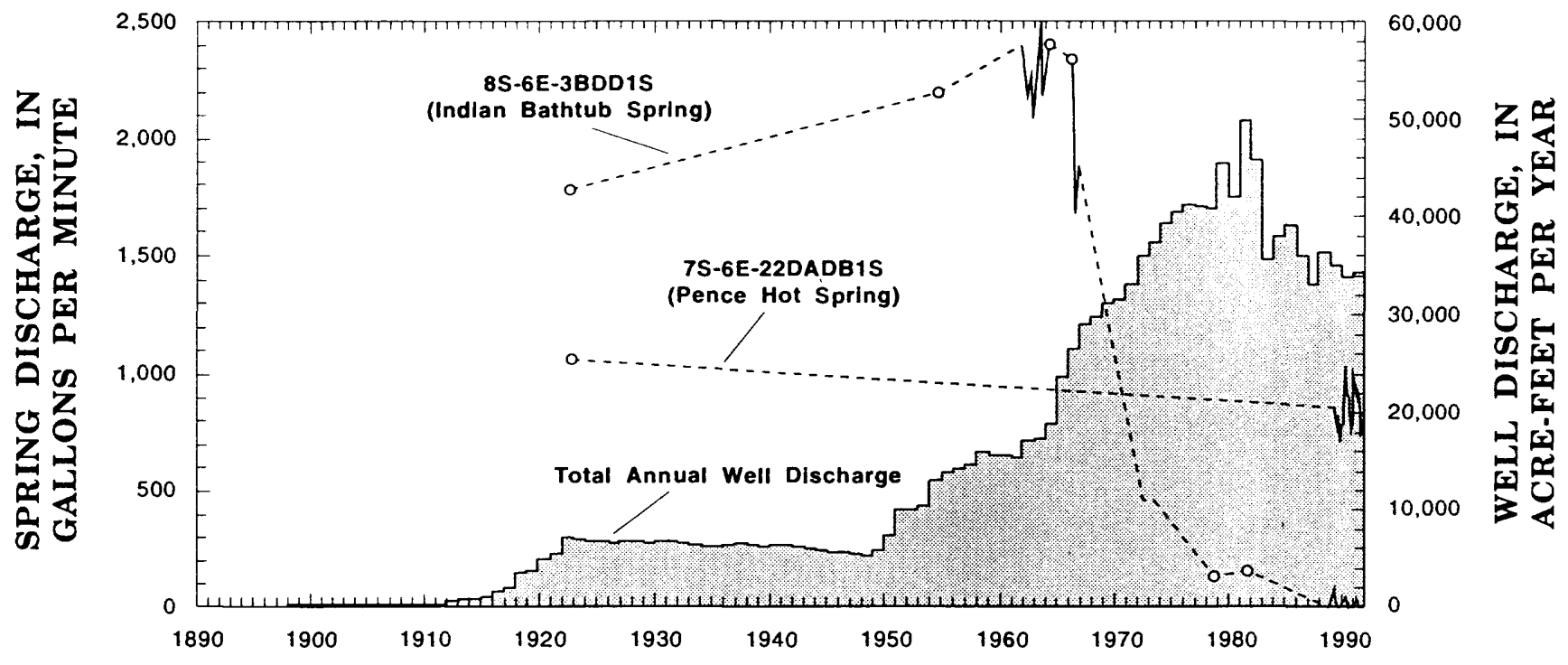

\section{EXPLANATION}

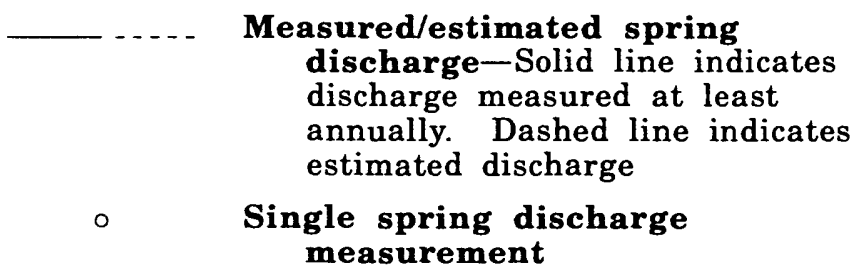

Figure 18. Discharge of Indian Bathtub and Pence Hot Springs and total annual well discharge in the Bruneau study area, 1890-1991. (Spring locations shown on fig. 2) 
effects of well discharges. Declines do not appear to be attributable to a single well or group of wells.

\section{Declines in Spring Discharge}

Within the past 25 years, discharge from monitored springs along Hot Creek and the Bruneau River has declined, most notably from Indian Bathtub Spring (8S-6E-3BDDIS). In the last several years, Indian Bathtub Spring has ceased to flow during the summer and early fall (Young and others, 1990, p. 15). The decline in spring discharges probably has minimal effect on ranchers and farmers who, in large part, do not rely on spring water; however, the cessation of some springs may adversely affect the Bruneau Hot Springs snail.

Discharge from wells (flowing and pumped) has caused hydraulic head in the regional geothermal aquifer system to decline, especially in the volcanic rocks. Discharges from Indian Bathtub Spring (8S-6E-3BDD1S) and Pence Hot Spring (7S-6E-22DADB1S) and total annual well discharge in the study area are shown in figure 18. Prior to 1966, discharge from Indian Bathtub Spring ranged from about 1,700 to $2,500 \mathrm{gal} / \mathrm{min}$, and discharge from wells was less than about 25,000 acre-ft/yr. After 1966, discharge from Indian Bathtub Spring began to decline and discharge from wells was greater than 25,000 acre$\mathrm{ft} / \mathrm{yr}$, reaching a maximum of about 49,900 acre- $\mathrm{ft}$ in 1981. Discharge from Indian Bathtub Spring has continued to decline since 1981 .

About 275,000 acre-ft of water has discharged from Indian Bathtub Spring since the first wells were drilled in 1896; only about 1,400 acre-ft was discharged during 1982-91. In contrast, discharge from Pence Hot Spring ranged from about 700 to $1,100 \mathrm{gal} / \mathrm{min}$ since 1922 (fig. 18) because the point of zero flow (pzf), or altitude of the point of discharge, is considerably lower than that of Indian Bathtub Spring. The pzf for Pence Hot Spring is about $2,585 \mathrm{ft}$, whereas the pzf for Indian Bathtub Spring is about $2,670 \mathrm{ft}$.

Changes in spring discharges are similar to changes in hydraulic heads, which fluctuate seasonally and are substantially less in late summer than in the spring (fig. 19). Discharges typically peak in March but were less during 1992 than dur- ing 1991, except for the spring at 7S-6E-34BCB IS. Monthly discharge measurements for four springs and the water level in test hole 8S-6E-3BDCl during April 1990 to April 1992 showed corresponding decreases and increases (figs. 12 and 19). The water level in test hole 8S-6E-3BDCl was used for comparison because it probably reflects the hydraulic head at Indian Bathtub Spring (8S-6E-3BDD1S, lower site; and 8S-6E-3BDD2S, vent) and continuous data are available since April 1990.

Because these springs discharge confined water (artesian springs), the quantity of discharge should follow Darcy's equation and be proportional to hydraulic head (see section, "Natural Recharge and Discharge"). If the length of the flowpath (length from the top of the confined aquifer to land surface), the cross-sectional area of the flowpath $(A)$, and the hydraulic conductivity $(K)$ are constant, spring discharge is linearly proportional to hydraulic head and can be plotted as a straight line on a rectangular grid. Data for 1990-92 were used to develop the hydraulic head/spring discharge relation. The relation between water level in test hole $8 \mathrm{~S}-6 \mathrm{E}-3 \mathrm{BDCl}$ and spring discharge is shown in figure 20. A hydraulic head/spring discharge relation probably exists because the data tend to follow some curve (figs. 20A and 20B). Data in figures $20 \mathrm{C}$ and 20D are more scattered and no one curve can reasonably represent the data, so no curves were developed. More data, especially in the upper and lower discharge ranges, are needed before a curve can be developed for these springs.

An important assumption made for the hydraulic head/spring discharge relation for springs at the lower (8S-6E-3BDD1S) and vent (8S-6E3BDD2S) sites at Indian Bathtub Spring was that no deposition or scour occurred in the Indian Bathtub area during 1990-92, the period used to develop a hydraulic head/spring discharge relation. Depositing or scouring of sediments on the floor of Indian Bathtub could change the pzf, or altitude of the discharge, because of the change in the altitude of the sediments; thus, the hydraulic head/spring discharge could change. H.W. Young (U.S. Geological Survey, oral commun., 1992) indicated that in 1964, probably no sediments existed on the floor of Indian Bathtub. By 1992, sediments probably less than $10 \mathrm{ft}$ thick covered the floor of Indian Bathtub. 
A. Indian Bathtub Spring at lower site (8S-6E-3BDD1S)

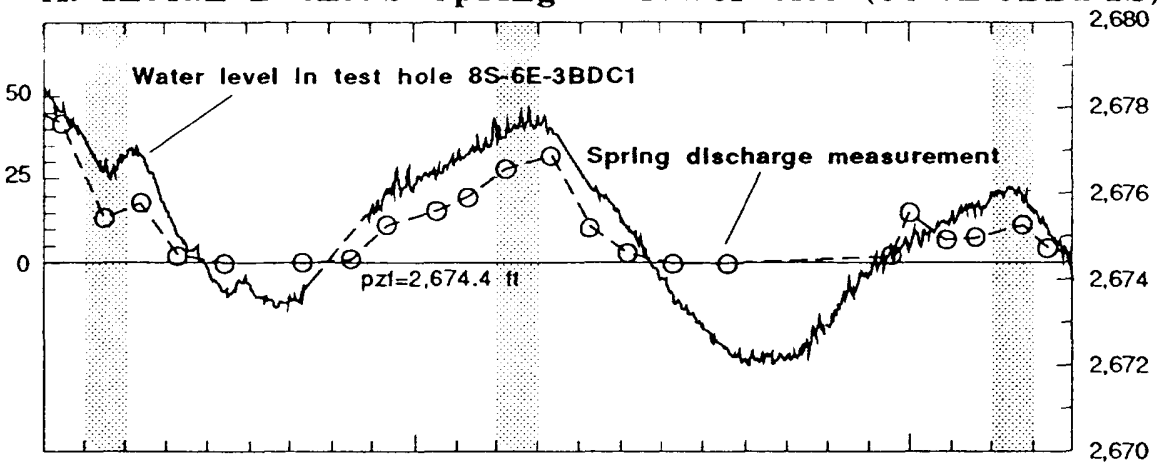

资

B. Indian Bathtub Spring at vent (8S-6E-3BDD2S)
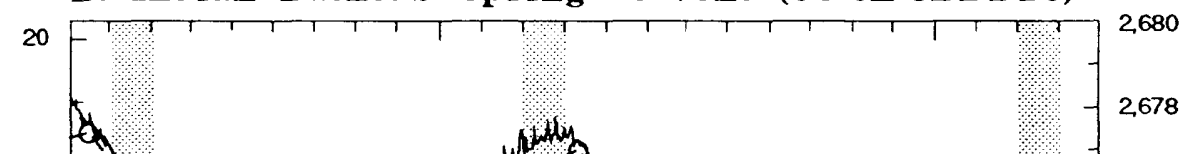

8

C. Spring (7S-6E-34DCB1S)

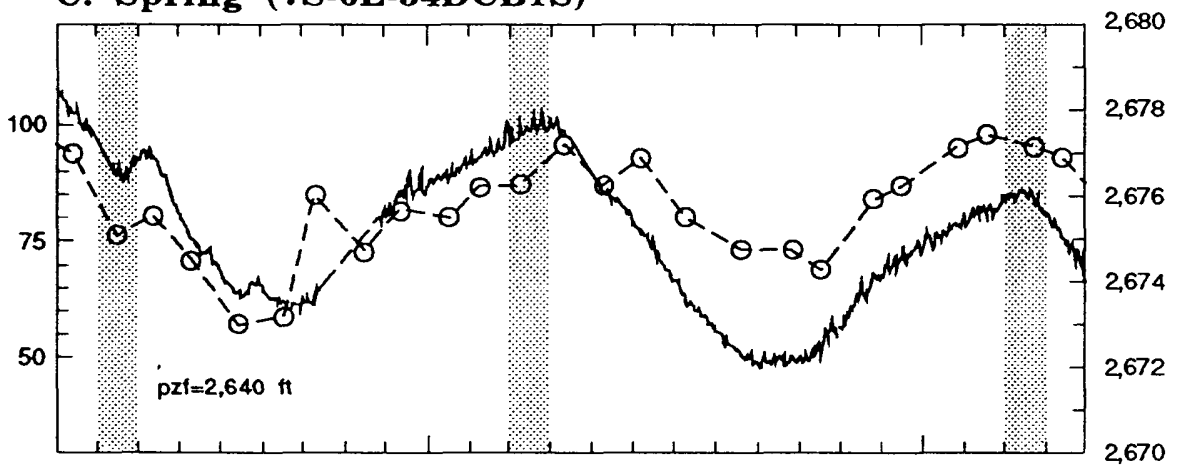

要

\section{Pence Hot Spring (7S-6E-22DADB1S)}

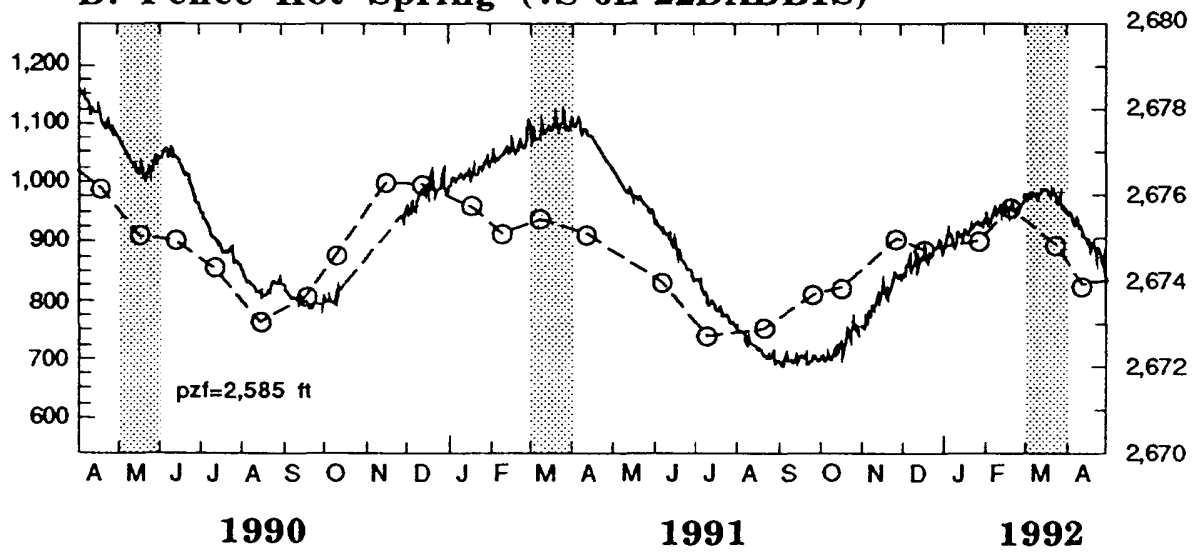

Figure 19. Hydrographs for test hole $8 \mathrm{~S}-6 \mathrm{E}-3 \mathrm{BDC} 1$ and spring discharge at four sites. (pzf, point of zero flow) 

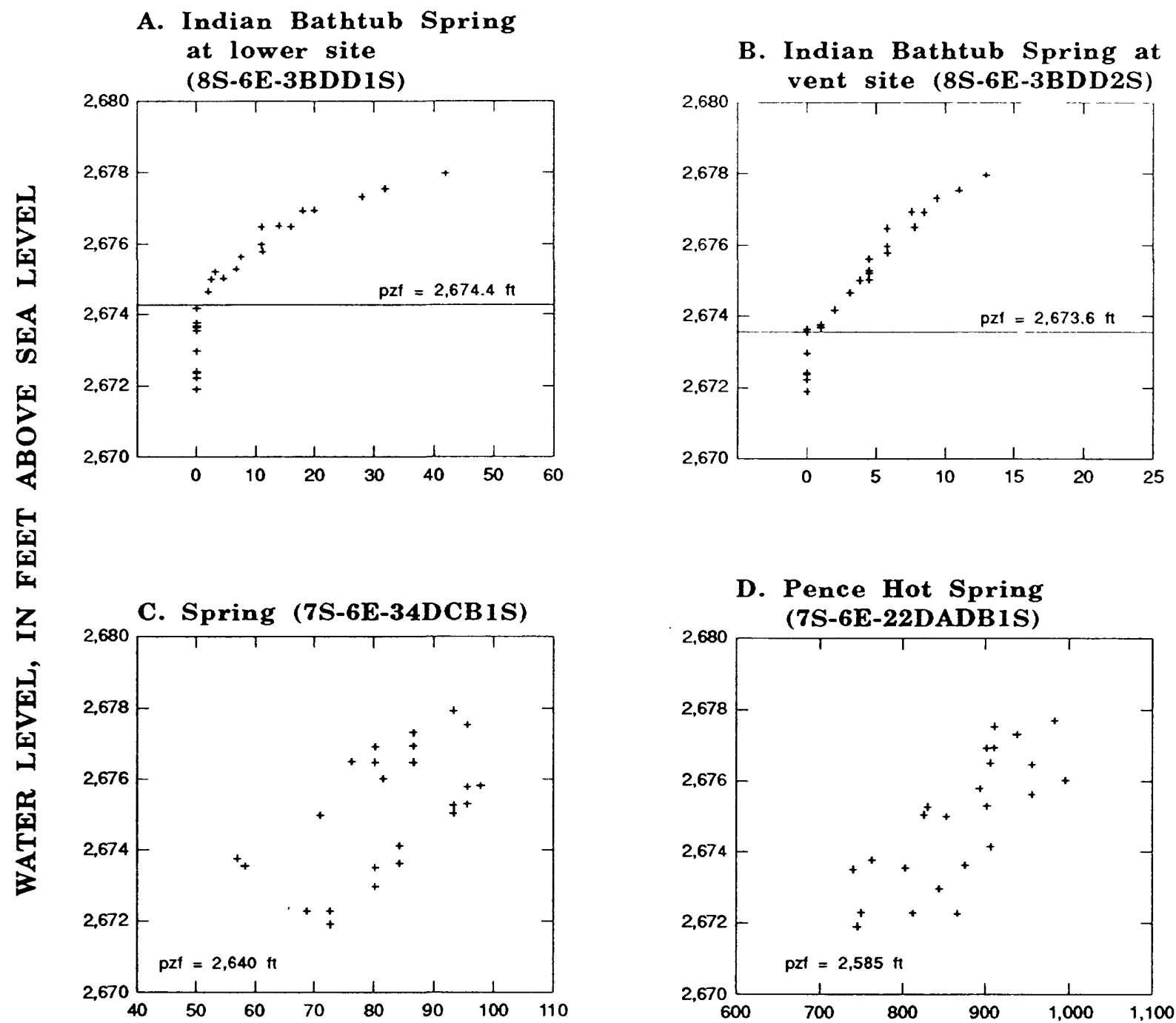

SPRING DISCHARGE, IN GALLONS PER MINUTE 
Hydraulic head/spring discharge relation curves (fig. 21) were developed for the lower (8S-6E-3BDD1S) and vent (8S-6E-3BDD2S) sites at Indian Bathtub Spring. Data for the lower site were plotted on a logarithmic grid instead of a rectangular grid because a straight line on log paper represents a curve that can be described by a few numbers or as a simple equation and can be extended more readily than a curved line. Discharge at the lower site is a combination of discharges from several springs. As hydraulic head increases, more vents near Indian Bathtub Spring will discharge water, thus increasing the cross-sectional area of flow and discharge. H.W. Young (U.S. Geological Survey, oral commun., 1992) indicated that several vents were contributing water to the lower site in the spring of 1990 , which resulted in a larger discharge at the lower site than at the vent (fig. 9). As hydraulic head and crosssectional area increase, a line curves more when plotted on a rectangular grid. A line was fitted to the data greater than about $7 \mathrm{gal} / \mathrm{min}$ because small spring discharges are greatly affected by (1) ground-water seepage into the shallow sediments, (2) evapotranspiration by vegetation, and (3) stream channel characteristics. H.W. Young (U.S. Geological Survey, oral commun., 1992) also indicated that when discharge is low at Indian Bathtub Spring, water can seep into the sediments and (or) the sediments can add water to Hot Creek before it is measured at the lower site. The curve for the lower site is defined by the equation, $Q=4.26(H E A D-2,674.4)^{1.8}$ and has an $r^{2}$ of 0.95

(fig. 21A). The value of $r^{2}$ is the proportion of the variation in the dependent variable, discharge $(Q)$, explained by regression on the independent variable, HEAD (Iman and Conover, 1983, p. 356).

The curve developed for the lower site describes the hydraulic head/spring discharge relation reasonably well for spring discharges less than about $50 \mathrm{gal} / \mathrm{min}\left(0.11 \mathrm{ft}^{3} / \mathrm{s}\right)$. Rantz and others (1982, p. 334) indicated that a discharge curve could be extrapolated two times beyond its greatest measured discharge. Accordingly, the curve in figure 2 I A could be extrapolated to about $85 \mathrm{gal} / \mathrm{min}$. However, the following is a method that shows how this curve can be extrapolated more than four- fold. On July 9, 1979, discharge from Indian Bathtub Spring was $160 \mathrm{gal} / \mathrm{min}$ (Young and others, 1979, p. 13), and the change in water level from 1979 to 1991 was $7.40 \mathrm{ft}$, based on the water level in well 7S-6E-34DAD1, about $1 \mathrm{mi}$ from Indian Bathtub Spring. If water level is assumed to be $2,681.80 \mathrm{ft}$ (where $2,674.4 \mathrm{ft}+7.40 \mathrm{ft}=$ $2,68 \mathrm{I} .80 \mathrm{ft}$ ), which is representative of the hydraulic head at Indian Bathtub Spring in 1979, spring discharge is calculated to have been about 156 $\mathrm{gal} / \mathrm{min}$, using the equation in figure $21 \mathrm{~A}$. This value is in agreement with the measured spring discharge and indicates that the curve can be extrapolated to at least $160 \mathrm{gal} / \mathrm{min}$.

However, a greater extrapolation is required to determine the hydraulic head at Indian Bathtub Spring because the discharge at the lower site was about 2,400 gal $/ \mathrm{min}$ before 1964 (fig. I8). If the extrapolated curve is assumed to describe the hydraulic head/spring discharge relation accurately for the entire range of spring discharge, a spring discharge of $2,400 \mathrm{gal} / \mathrm{min}$ would relate to a hydraulic head of about $2,708 \mathrm{ft}$, or about $34 \mathrm{ft}$ $(2,708 \mathrm{ft}-2,674.4 \mathrm{ft} \cong 34 \mathrm{ft})$ higher than it is presently at zero discharge. A hydraulic head decline of $34 \mathrm{ft}$ at Indian Bathtub Spring is probably reasonable because many wells in the study area have had similar declines (see section, "Declines in Hydraulic Head").

A hydraulic head/spring discharge relation curve for the vent site at Indian Bathtub Spring (8S-6E-3BDD2S) is shown in figure 21B. The curve for the vent site is defined by the equation, $Q=2.64(H E A D-2,673.6)$ and has an $r^{2}$ of 0.98 . The curve was forced to go through zero; thus, the intercept equals zero. Data for the vent site and curve were plotted on a rectangular grid because a straight line could be plotted. Some quantity of water seeps into the sediments or is evapotranspired but is probably not as much as at the lower site because discharge is measured near the vent in the volcanic rocks. A line was fitted to the data and an equation for the line was developed. This curve can be extrapolated to a maximum of about $26 \mathrm{gal} / \mathrm{min}$. Higher discharges at the vent site probably could not be measured because other vents would start to flow and, upon merging, 
A. Indian Bathtub Spring at

lower site (8S-6E-3BDD1S)

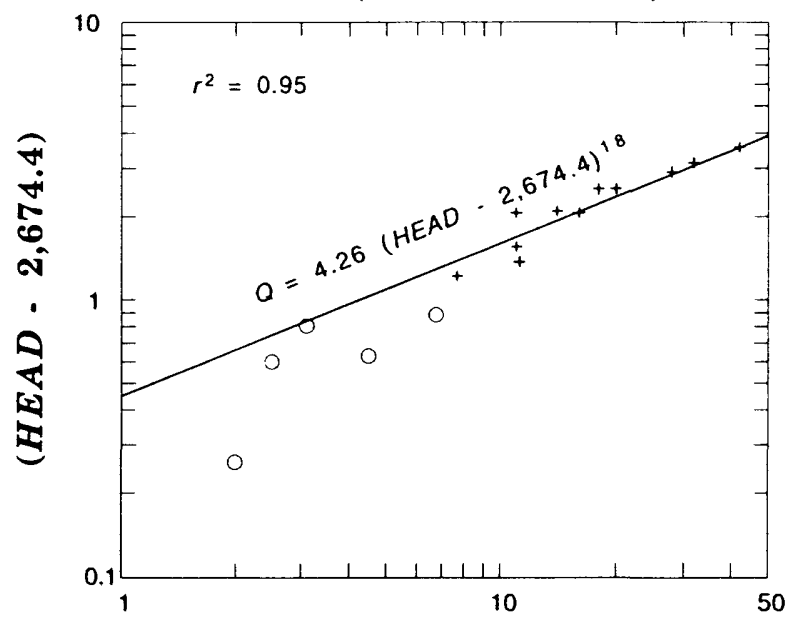

Where:

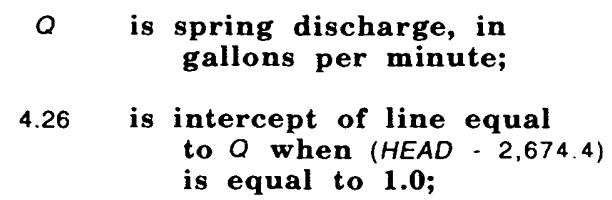

$H E A D$ is water level in test hole 8S-6E-3BDC1, in feet above sea level;

$2,674.4$ is point of zero flow (pzf); and

1.8 is slope of line.

Data not used in regression

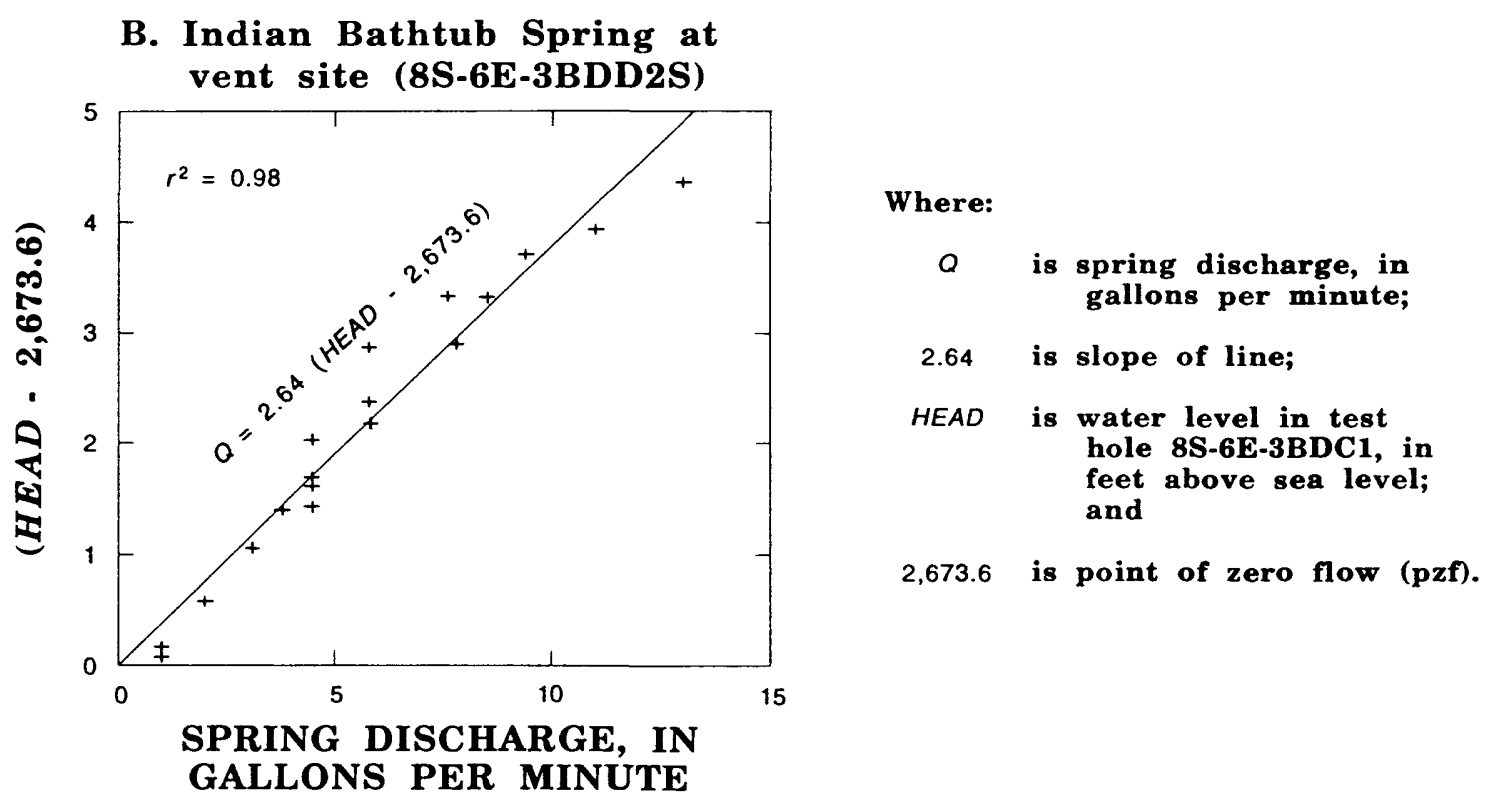

Figure 21. Relation between hydraulic head and discharge at Indian Bathtub Spring, lower and vent sites. 
would nullify the relation. If the curve accurately represents the discharge of water from the vent site for the entire range of discharge, a hydraulic head increase of $34 \mathrm{ft}$ would cause a spring discharge of about $90 \mathrm{gal} / \mathrm{min}$. It is not known whether this value is reasonable, because each vent or discharge point cannot be measured separately at high spring discharges.

\section{SUMMARY}

This report describes results of a study to determine the cause or causes of declining flow at Indian Bathtub Spring that is adversely affecting a unique species of snail that inhabits the spring.

The Bruneau study area of about $600 \mathrm{mi}^{2}$ includes the northern part of the Bruneau River drainage basin and Indian Bathtub area. The study area includes Bruneau, Little, and Sugar Valleys, which are separated by plateaus several hundred feet higher than the valley floors and included streams. Many faults cross the study area. They enhance and provide conduits for ground-water flow, horizontally and vertically.

The Bruneau area is underlain by sedimentary and volcanic rocks. The sedimentary rocks consist predominantly of fine sand, silt, and clay of low permeability with some included gravel and volcanic rocks. The sedimentary rocks range in thickness from zero in the southern part of the study area to more than $3,000 \mathrm{ft}$ in the northeastern part and underlie about $500 \mathrm{mi}^{2}$ of the study area. The volcanic rocks consist of basalt and silicic rocks with some interbedded sedimentary rocks. The thickness of the volcanic rocks is largely unknown but is probably 2,000 to $3,000 \mathrm{ft}$. For this study, the regional geothermal aquifer system was divided into sedimentary- and volcanic-rock aquifers. The sedimentary rocks are part of a more extensive aquifer in the western Snake River Plain. Volcanic rocks are present throughout the study area and extend southward to the Jarbidge Mountains. In the northern part of the study area, the volcanic-rock aquifer underlies the sedimentaryrock aquifer and water is confined in both.

Transmissivity of the volcanic rocks, as estimated from aquifer and slug tests, ranged from about 25 to $100,000 \mathrm{ft}^{2} / \mathrm{d}$. Low values were obtained from tests in two wells about $23 \mathrm{mi}$ south of Indian Bathtub and are indicative of massive, unfractured silicic volcanic rocks as compared with the highly fractured volcanic rocks in the Bruneau study area. Transmissivity and hydraulic conductivity, estimated from specific-capacity tests, ranged from $1,700 \mathrm{ft}^{2} / \mathrm{d}$ and $0.7 \mathrm{ft} / \mathrm{d}$ for the sedimentary-rock aquifer to $980,000 \mathrm{ft}^{2} / \mathrm{d}$ and $390 \mathrm{ft} / \mathrm{d}$ for the volcanicrock aquifer. In general, transmissivities in the sedimentary-rock aquifer decrease from south to north because of the increase in fine-grained rocks toward the Snake River.

Generally, ground water moves northward from areas of recharge along the Jarbidge and Owyhee Mountains toward the study area, where it is discharged as spring flow or leaves the study area as underflow. Natural recharge to the study area was estimated by the basin yield method for the period 1934-80 to be about 57,000 acre-ft/yr.

Ground water for irrigation in the late 1890's was first obtained from flowing wells. From 1890 to 1981, discharge from flowing or pumped irrigation wells increased from 0 to about 49,900 acre-ft/yr. After 1981, discharge decreased and was about 34,700 acre-ft in 1991 . Through 1991 , nearly $1,400,000$ acre- $f t$ of ground water discharged from wells in the study area. Of that quantity, about 546,000 acre-ft discharged from 1978 through 1991. Most pumped water is from wells completed in the volcanic-rock aquifer and farther than $5 \mathrm{mi}$ from Indian Bathtub Spring.

Ground-water movement in the sedimentaryand volcanic-rock aquifers in spring 1989 generally was from south to north toward the Snake River. Four depressions, created by heavy pumping for irrigation, were evident on the potentiometric surface in the study area. Two depressions were in the northern part of the study area in the sedimentary-rock aquifer. The other two depressions were near the southern end of Bruneau and Little Valleys, where most of the wells are completed in volcanic rocks. Hydraulic head in the volcanic-rock aquifer is about $25 \mathrm{ft}$ higher than head in the sedimentary-rock aquifer and, in places, is as much as $50 \mathrm{ft}$ higher.

Long-term hydraulic heads in the sedimentaryrock aquifer have not changed significantly since the mid-1950's, but in the volcanic-rock aquifer, heads have declined several tens of feet. Water levels in three wells in the volcanic-rock aquifer in Little Valley have declined about 70,45 , and $30 \mathrm{ft}$ since the mid-1950's. Seasonally, hydraulic heads fluctuate in 
response to pumping and natural recharge; heads are generally highest in March-April and lowest in September-October.

Within the past 25 years, discharge from monitored springs along Hot Creek and the Bruneau River has declined, most notably from Indian Bathtub Spring. From the late 1890's through 1991 , nearly 275,000 acre-ft of water discharged from Indian Bathtub Spring. Of this quantity, about 1,400 acre-ft was discharged during 198291. Discharge from Indian Bathtub Spring began to decline in the mid-1960's when well discharge accelerated. Discharge from Pence Hot Spring has ranged from about 700 to $1,100 \mathrm{gal} / \mathrm{min}$ since 1922.

Changes in discharge from monitored springs are similar to changes in hydraulic head, which fluctuates seasonally and is substantially less in late summer than in the spring. A hydraulic head/ spring discharge relation was developed for two sites at Indian Bathtub Spring and a nearby test hole. The relation for Indian Bathtub Spring indicated that a spring discharge of $2,400 \mathrm{gal} / \mathrm{min}$, as in 1964 , would relate to a hydraulic head of about $2,708 \mathrm{ft}$, or about $34 \mathrm{ft}$ higher than the head at zero discharge. Hydraulic head declines of $34 \mathrm{ft}$ at the Indian Bathtub area are probably reasonable because a similar magnitude of decline has been measured elsewhere in the area.

\section{REFERENCES CITED}

Allen, R.G., and Brockway, C.E., 1983, Estimating consumptive irrigation requirements for crops in Idaho: Moscow, Idaho Water and Energy Resources Research Institute, University of Idaho, Research Technical Completion Report, 183 p.

Baker, C.H., Jr., 1977, WATSTORE user's guide, volume 2 and appendix F: U.S. Geological Survey Open-File Report 75-4589, 537 p.

Bigelow, B.B., Goodell, S.A., and Newton, G.D., 1987 [1986], Water withdrawn for irrigation in 1980 on the Snake River Plain, Idaho and eastern Oregon: U.S. Geological Survey Hydrologic Investigations Atlas HA-690, 2 sheets, scale $1: 1,000,000$.
Bouwer, Herman, 1978, Ground water hydrology: New York, McGraw-Hill, 480 p.

Brook, C.A., and others, 1979, Hydrothermal convection systems with reservoir temperatures $\geq 90^{\circ} \mathrm{C}$, in Assessment of geothermal resources of the United States: U.S. Geological Survey Circular 790, 163 p.

Cooper, H.H., Jr., Bredehoeft, J.D., and Papadopulos, S.S., 1967, Response of a finitediameter well to an instantaneous discharge of water: Water Resources Research, v. 3, p. $263-269$.

Driscoll, F.G., 1986, Groundwater and wells (2d ed.): St. Paul, Minn., Johnson Division, $1,089 \mathrm{p}$.

Farnsworth, R.K., Thompson, E.S., and Peck, E.L., 1982, Evaporation atlas for the contiguous 48 United States: U.S. Department of Commerce, National Oceanic and Atmospheric Administration Technical Report NWS33, $26 \mathrm{p}$.

Gemperle, R.J., 1988, Analysis of ground water resource conditions and management alternatives for the Bruneau-Grand View area, southwestern Idaho: Moscow, University of Idaho, M.S. thesis, $120 \mathrm{p}$.

Goodell, S.A., 1988, Water use on the Snake River Plain, Idaho and eastern Oregon: U.S. Geological Survey Professional Paper 1408-E, $51 \mathrm{p}$.

Harper, K.R., 1963, Geology of the Hot Springs Quadrangle, Owyhee County, Idaho: Eugene, University of Oregon, M.S. thesis, 107 p.

Heath, R.C., 1983, Basic ground-water hydrology: U.S. Geological Survey Water-Supply Paper 2220, $84 \mathrm{p}$.

Hill, D.P., 1963, Gravity and crustal structure in the western Snake River Plain, Idaho: Journal of Geophysical Research, v. 68, no. 20, p. 5,807-5,819.

Iman, R.L., and Conover, W.J., 1983, A modern approach to statistics: New York, John Wiley and Sons, $497 \mathrm{p}$.

Kipp, K.L., Jr., 1985, Type curve analysis of inertial effects in the response of a well to a slug test: Water Resources Research, v. 21, no. 9, p. 1,397-1,408. 
Kjelstrom, L.C., 1986, Flow characteristics of the Snake River and water budget for the Snake River Plain, Idaho and eastern Oregon: U.S. Geological Survey Hydrologic Investigations Atlas HA-680, 2 sheets, scale $1: 1,000,000$.

\section{2, Streamflow gains and losses in the} Snake River and ground-water budgets for the Snake River Plain, Idaho and eastern Oregon: U.S. Geological Survey Open-File Report 90-172, 71 p.

Lindholm, G.F., 1981, Plan of study for the regional aquifer-system analysis of the Snake River Plain, Idaho and eastern Oregon: U.S. Geological Survey Open-File Report 81-689, 21 p.

Lindholm, G.F., Garabedian, S.P., Newton, G.D., and Whitehead, R.L., 1983, Configuration of the water table, March 1980, in the Snake River Plain regional aquifer system, Idaho and eastern Oregon: U.S. Geological Survey Open-File Report 82-1022, 1 sheet, scale 1:500,000.

1988 [1987], Configuration of the water table and depth to water, spring 1980 , water-level fluctuations, and water movement in the Snake River Plain regional aquifer system, Idaho and eastern Oregon: U.S. Geological Survey Hydrologic Investigations Atlas HA-703, 1 sheet, scale 1:500,000.

Lindholm, G.F., and Goodell, S.A., 1986, Irrigated acreage and other land uses on the Snake River Plain, Idaho and eastern Oregon: U.S. Geological Survey Hydrologic Investigations Atlas HA-691, 1 sheet, scale 1:500,000.

Littleton, R.T., and Crosthwaite, E.G., 1957, Ground-water geology of the Bruneau-Grand View area: U.S. Geological Survey WaterSupply Paper 1460-D, $198 \mathrm{p}$.

Lohman, S.W., 1972, Ground-water hydraulics: U.S. Geological Survey Professional Paper $708,70 \mathrm{p}$.

Malde, H.E., and Powers, H.A., 1962, Upper Cenozoic stratigraphy of the western Snake River Plain, Idaho: Geological Society of America Bulletin, v. 73, p. 1,197-1,220.

Malde, H.E., Powers, H.A., and Marshall, C.H., 1963, Reconnaissance geologic map of the west-central Snake River Plain, Idaho:
U.S. Geological Survey Miscellaneous Investigations Series Map I-373, 1 sheet, scale $1: 125,000$.

McIntyre, D.H., 1979, Preliminary description of Anschutz Federal No. 1 drill hole, Owyhee County, Idaho: U.S. Geological Survey OpenFile Report 79-651, 15 p.

Moffatt, R.L., and Jones, M.L., 1984, Availability and chemistry of ground water on the Bruneau plateau and adjacent eastern plain in Twin Falls County, south-central Idaho: U.S. Geological Survey Water-Resources Investigations Report 84-4065, 43 p.

Newton, G.D., 1991, Geohydrology of the regional aquifer system, western Snake River Plain, southwestern Idaho: U.S. Geological Survey Professional Paper 1408-G, 52 p.

Piper, A.M., 1924, Geology and water resources of the Bruneau River basin, Idaho: Moscow, Idaho Bureau of Mines and Geology, Pamphlet $11,56 \mathrm{p}$.

Ralston, D.A., and Chapman, S.L., 1969, Groundwater resource of northern Owyhee County, Idaho: Idaho Department of Reclamation, Water Information Bulletin no. 14, 85 p.

Rantz, S.E., and others, 1982, Measurement and computation of streamflow; volume 2, Computation of discharge: U.S. Geological Survey Water-Supply Paper 2175, p. 285-631.

Renner, J.L., White, D.E., and Williams, D.L., 1975, Hydrothermal convection system, in White, D.E., and Williams, D.L., eds., Assessment of geothermal resources of the United States-1975: U.S. Geological Survey Circu$\operatorname{lar} 726,155 \mathrm{p}$.

Rightmire, C.T., Young, H.W., and Whitehead, R.L., 1976, Geothermal investigations in Idaho, Part 4, Isotopic and geochemical analyses of water from the Bruneau-Grand View and Weiser areas, southwest Idaho: Idaho Department of Water Resources, Water Information Bulletin no. 30, 28 p.

Ross, S.H., 1971, Geothermal potential of Idaho: Moscow, Idaho Bureau of Mines and Geology, Pamphlet 150, $72 \mathrm{p}$.

Russell, I.C., 1903, Preliminary report on artesian basins in southwestern Idaho and southeastern Oregon: U.S. Geological Survey Water-Supply Paper 78, p. 24-26. 
Stearns, H.T., 1922, Artesian water near Grand View, Owyhee County, Idaho: U.S. Geological Survey Open-File Report, 10 p.

Stearns, N.D., Stearns, H.T., and Waring, G.A., 1937, Thermal springs in the United States: U.S. Geological Survey Water-Supply Paper 679-B, 200 p.

Stephenson, G.R., and Zuzel, J.F., 1981, Groundwater recharge characteristics in a semiarid environment of southwest Idaho: Journal of Hydrology, v. 53, p. 213-227.

van der Kamp, Garth, 1976, Determining aquifer transmissivity by means of well response tests - The underdamped case: Water Resources Research, v. 12, no. 1, p. 71-77.

Whitehead, R.L., 1986, Geohydrologic framework of the Snake River Plain, Idaho and eastern Oregon: U.S. Geological Survey Hydrologic Investigations Atlas HA-681, 3 sheets, scale $1: 1,000,000$.

-1992, Geohydrologic framework of the Snake River Plain, Idaho and eastern Oregon: U.S. Geological Survey Professional Paper 1408-B, 32 p.

Young, H.W., Jones, M.L., Parliman, D.J., and Tungate, A.M., 1990, Results of test drilling and hydrologic monitoring in the Indian Bathtub area, Owyhee County, southwestern Idaho, January 1989 through September 1990: U.S. Geological Survey Open-File Report 90-597, 40 p.
Young, H.W., and Lewis, R.E., 1982, Hydrology and geochemistry of thermal ground water in southwestern Idaho and north-central Nevada: U.S. Geological Survey Professional Paper 1044-J, $20 \mathrm{p}$.

Young, H.W., Lewis, R.E., and Backsen, R.L., 1979, Thermal ground-water discharge and associated convective heat flux, Bruneau-Grand View area, southwest Idaho: U.S. Geological Survey Water-Resources Investigations Report 79-62, $17 \mathrm{p}$.

Young, H.W., and Mitchell, J.C., 1973, Geothermal investigations in Idaho, Part 1, Geochemistry and geologic setting of selected thermal waters: Idaho Department of Water Resources, Water Information Bulletin no. 30, 43 p.

Young, H.W., and Parliman, D.J., 1989, Hydrologic and chemical data for selected thermal-water wells and springs in the Indian Bathtub area, Owyhee County, southwestern Idaho: U.S. Geological Survey Open-File Report 89-589, $19 \mathrm{p}$.

Young, H.W., and Whitehead, R.L., 1975, Geothermal investigations in Idaho, Part 2, An evaluation of thermal water in the Bruneau-Grand View area, southwest Idaho: Idaho Department of Water Resources, Water Information Bulletin no. 30,126 p. 